\title{
IUCN
}

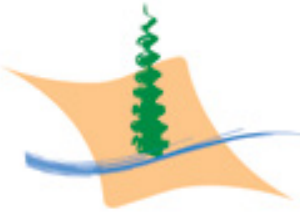

Haut Commissariat aux Eaux et Forets et a la Lutte Contre la Désertification

\section{Conservation Strategy and Action Plan for the Great Bustard (Otis tarda) in Morocco}

2016-2025

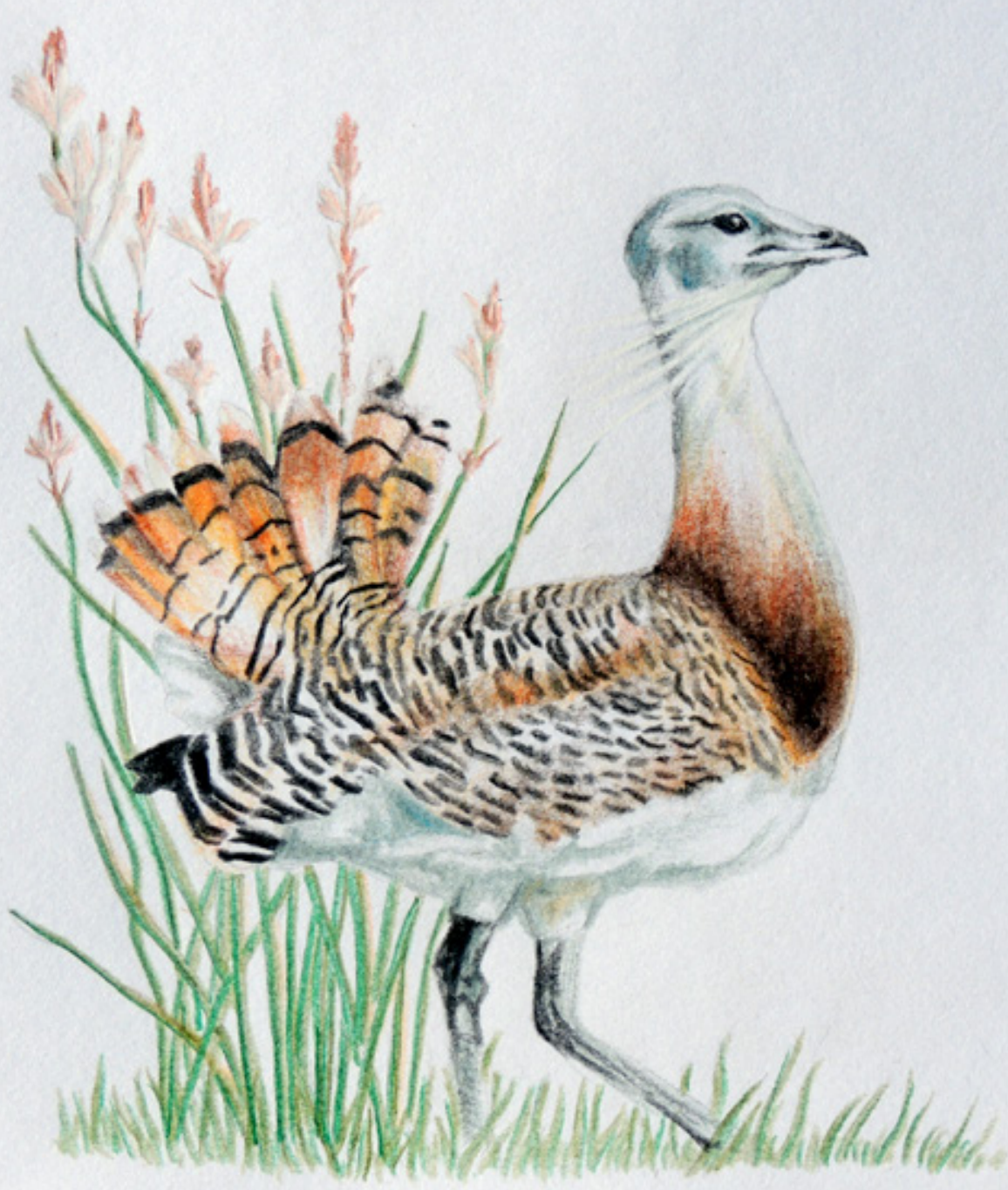




\title{
About IUCN
}

IUCN, International Union for Conservation of Nature, helps the world find pragmatic solutions to our most pressing environment and development challenges.

IUCN's work focuses on valuing and conserving nature, ensuring effective and equitable governance of its use, and deploying naturebased solutions to global challenges in climate, food and development. IUCN supports scientific research, manages field projects all over the world, and brings governments, NGOs, the UN and companies together to develop policy, laws and best practice.

IUCN is the world's oldest and largest global environmental organization, with more than 1,200 government and NGO Members and almost 11,000 volunteer experts in some 160 countries. IUCN's work is supported by over 1,000 staff in 45 offices and hundreds of partners in public, NGO and private sectors around the world.

www.iucn.org

\section{About the IUCN Centre for Mediterranean Cooperation}

The IUCN Centre for Mediterranean Cooperation was opened in October 2001 with the core support of the Spanish Ministry of Environment, the regional Government of Junta de Andalucía and the Spanish Agency for International Cooperation and Development (AECID). The mission of IUCN-Med is to influence, encourage and assist Mediterranean societies to conserve and sustainably use natural resources in the region, working with IUCN members and cooperating with all those sharing the same objectives of IUCN. www.iucn.org/mediterranean

\section{About the IUCN Species Survival Commission}

The Species Survival Commission (SSC) is the largest of IUCN's six volunteer commissions with a global membership of 9,000 experts. SSC advises IUCN and its members on the wide range of technical and scientific aspects of species conservation and is dedicated to securing a future for biodiversity. SSC has significant input into the international agreements dealing with biodiversity conservation. www.iucn.org/about/work/programmes/species/who_we_are/about_the_species_survival_commission_/

\begin{abstract}
About the Species Conservation Planning Sub-Committee
The Species Conservation Planning Sub-Committee (SCPSC) was established in 2010, answering to the Species Survival Commission (SSC) Steering Committee. Its purpose is to disseminate the philosophy, methodologies and processes for effective species planning deriving from the 2008 Strategic Planning for Species Conservation Handbook*. Members of the SCPSC work with many of the SSC's 120 Specialist Groups on their species planning activities, but are also consulted by international conventions and government institutions on planning approaches. One goal of the SCPSC is to establish a bench mark of good practice for conserving species. This will contribute to planning for the vast diversity of species needing conservation support and the multitude of conditions under which these species exist.
\end{abstract}

The SCPSC is the means for SSC to build on Red List assessments, and to contribute to IUCN's efforts to meet a milestone global challenge: the Convention on Biological Diversity's Biodiversity Target 12 for 2010-2020 which states that by 2020 the extinction of known threatened species has been prevented and their conservation status, particularly of those most in decline, has been improved and sustained.

* http://cmsdata.iucn.org/downloads/scshandbook_2_12_08_compressed.pdf

\section{About the IUCN Bustard Specialist Group}

The current mission of this deliberately small group is to advise on, support and contribute to the conservation of the three highly threatened bustards in the Indian subcontinent and Cambodia, namely Great Indian Bustard Ardeotis nigriceps (Critically Endangered), Bengal Florican Houbaropsis bengalensis (Critically Endangered) and Lesser Florican Sypheotides indica (Endangered). In due course it will expand to provide particular support for other species, but it recognises that functioning networks of world experts already exist for Palearctic species, including the Great Bustard.

www.iucn.org/about/work/programmes/species/who_we_are/ssc_specialist_groups_and_red_list_authorities_directory/birds/

\section{About the High Commission for Water, Forests and Desertification Control}

The Haut Commissariat aux Eaux et Forêts et à la Lutte Contre la Désertification (HCEFLCD) of Morocco is the institution in charge of preparing and implementing the government policy related to the conservation and sustainable use of forestry, esparto and silvo-pastoral resources in the areas under a forestry regime, as well as the development of hunting, continental fishing and natural parks and reserves.

In this respect, the aim of the HCEFLCD includes conserving and protecting biodiversity in general, and wildlife and habitats in particular, through rehabilitation of ecosystems and protection of natural areas and threatened or endangered species.

www.eauxetforets.gov.ma/fr/index.aspx 


\section{Conservation Strategy and Action Plan for the Great Bustard (Otis tarda) in Morocco}

\section{6-2025}

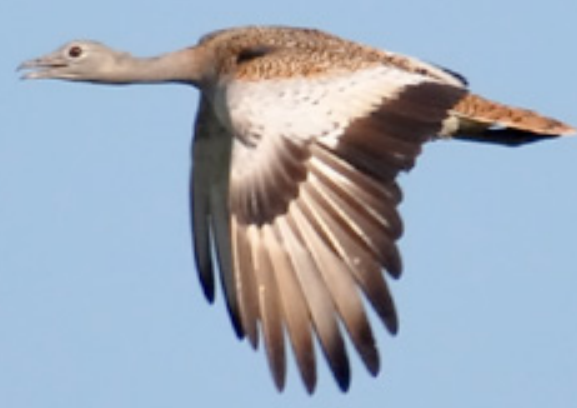


The designation of geographical entities in this book and the presentation of the material do not imply the expression of any opinion whatsoever on the part of IUCN or other participating organizations concerning the legal status of any country, territory, or area, or of its authorities, or concerning the delimitation of its frontiers or boundaries. The views expressed in this publication do not necessarily reflect those of IUCN or other participating organizations.

Published by: IUCN Malaga, Spain and HCEFLCD, Kingdom of Morocco

\section{Copyright: $\quad$ C 2016 International Union for Conservation of Nature and Natural Resources}

Citation: $\quad$ IUCN and HCEFLCD (2016). Conservation Strategy and Action Plan for the Great Bustard (Otis tarda) in Morocco 2016-2025. Malaga, Spain: IUCN/HCEFLD. 48 pp.

ISBN:

ISBN: 978-2-8317-1743-2

DOI:

English version: 10.2305/IUCN.CH.2015.SSC-AP.10.en

Cover images: [front cover] Great Bustard illustration by Cassia Dodman [title page] Great Bustard photographed during the Moroccan Great Bustard census in March 2015. Photo @ Rachid El Khamlichi [back cover] Male Great Bustard displaying. Photo @ Carlos Palacín

Layout by: $\quad$ Alex Storer (IDFP Creative Design), United Kingdom

Available from: $\quad$ IUCN Centre for Mediterranean Cooperation

\section{$\mathrm{C} /$ Marie Curie 22}

29590 Campanillas

Malaga, Spain

Tel: +34 952028430 - Fax: +34 952028145

www.iucn.org/mediterranean

www.iucn.org/publications

This publication was funded by MAVA Foundation in the framework of the project Improving capacity for species conservation in the Mediterranean region: Training in the preparation and implementation of Species Conservation Strategies in three Maghreb countries'.

Compiled and edited by Tim Dodman with contributions from (in alphabetical order) Maknass Abdellilah, Rachid Aboulouafae, Elisa Alcázar, Juan Carlos Alonso, Zouhair Amhaouch, Zinelaabidin Arhzaf, Violeta Barrios, Abdelaziz Bouabbad, Adel Bouajaja, Med Bousfizza, Abderraouf Britel, Nigel Collar, Younis Chaker, Said Chakri, Imad Cherkaoui, Azizi Driss, Mohammed Aziz El Agbani, Abdelaziz El Idrissi Essougrati, Rachid El Khamlichi, Brahim Haddane, Oumnia Himmi, Ksassoua Kébir, Chris Magin, David Mallon, Hayat Mesbah, Mohamed Noaman, Catherine Numa, Azzat Ouafae, Carlos Palacín, Abdeljebbar Qninba, Rainer Raab, Mohamed Radi, Ahmed Salmi M'rabet, Sonsoles San Román, Mustapha Sidi Ben Salah, Michel Thévenot and Antonio Troya. 


\section{Table of contents}

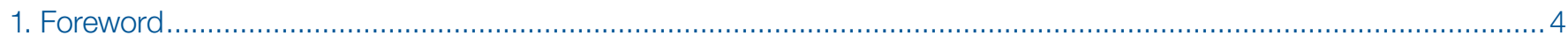

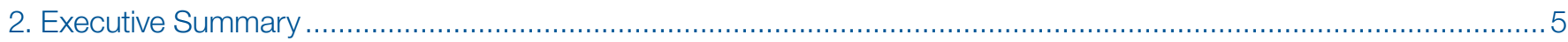

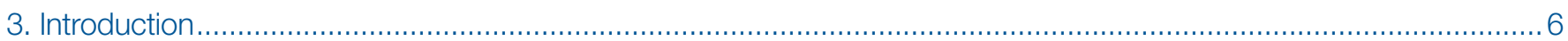

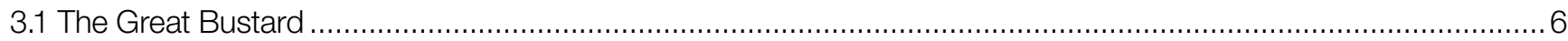

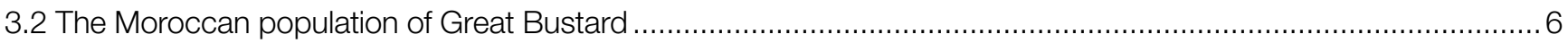

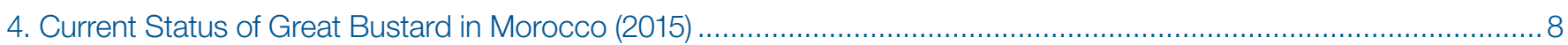

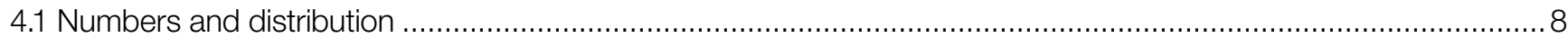

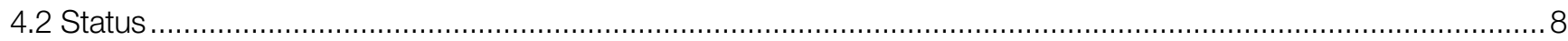

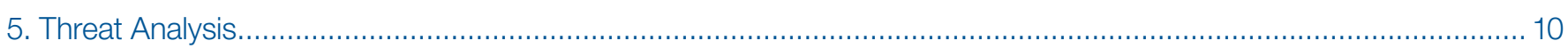

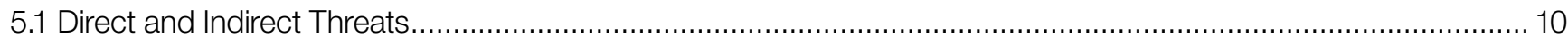

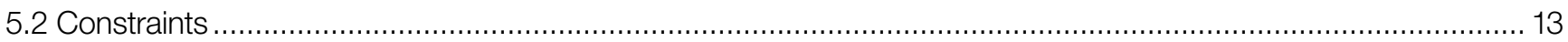

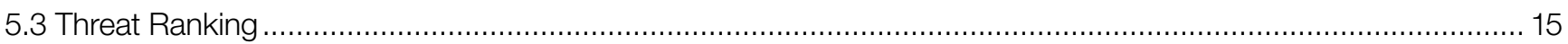

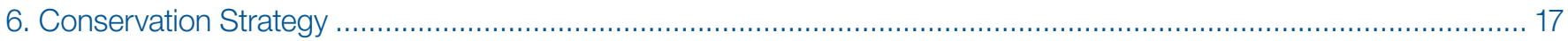

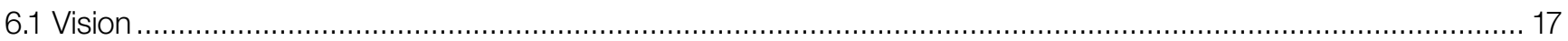

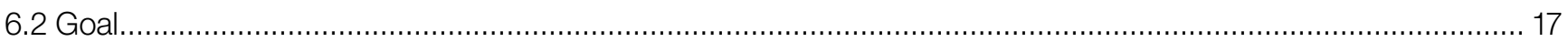

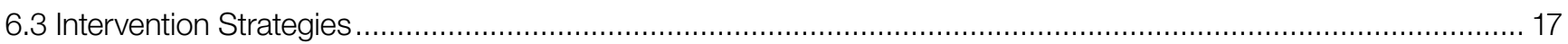

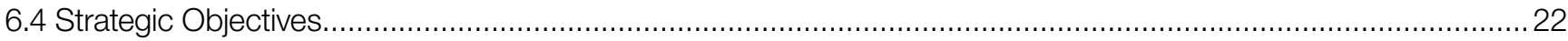

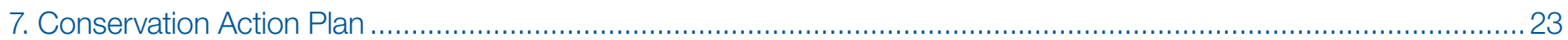

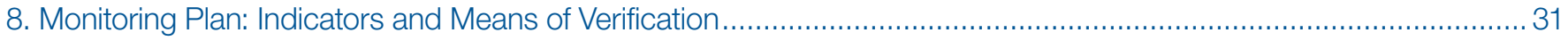

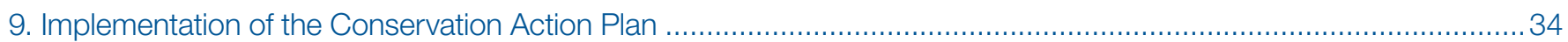

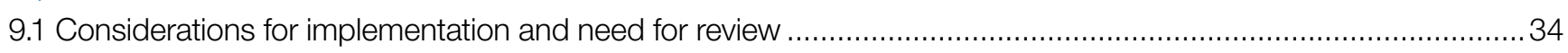

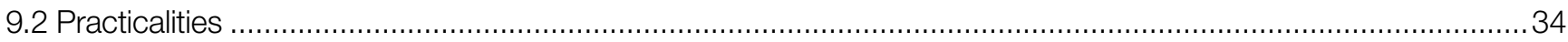

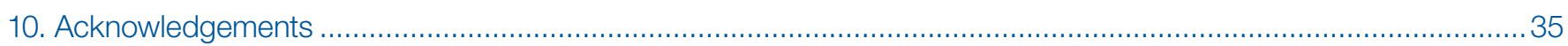

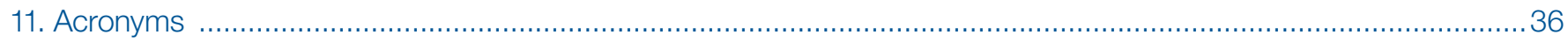

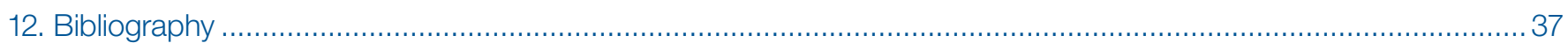

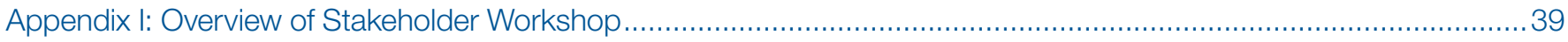

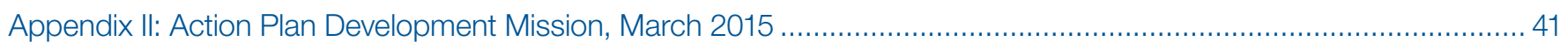




\section{Foreword}

\section{'To conserve Great Bustards we need do very little', wrote Wolfgang Gewalt in his pioneering monograph Die Grosstrappe (1959), 'but there is a lot we must not do'.}

He was making an important point. Left alone, the Great Bustard can survive and multiply well enough. It does not need close management and manipulation of the type that certain other threatened species need to help them survive. It can look after itself.

But it is a highly traditional species. The places where it displays each spring - the 'leks' - are the same from year to year. The males appear to be 'imprinted' on the landscape where they parade. The females come to the leks to select a mate, and then retreat into cover, usually not more than a few kilometres away, to rear their young alone. The young males may wander to another lek, if there is one; the young females tend to stay where they were born. Everything works well in this system as long as nothing changes.

The species has fared a little better in Morocco than two other members of its family. A hundred years ago the Little Bustard Tetrax tetrax was common in farmland across northern Morocco, while the Arabian Bustard Ardeotis arabs could be found in at least half-a-dozen places. The two species, one Palearctic, the other Afrotropical, were present together in and around Mamora Forest near Rabat - what a glorious thought! But from causes too distant in time to be identified with confidence, the Little Bustard is now more threatened in Morocco than the Great, and the Arabian has now gone completely.

The same fate is about to befall the country's last Great Bustards. As the evidence assembled in this excellent action plan shows, the population of the species has slowly but inexorably dwindled over the past two decades, and is now at a critical point. The number of males remaining is now so low that the loss of even one of them will be a blow to the survival of the species in Africa.

Why has it come to this? Because something has changed; or, far more likely, some things have changed. Illegal hunting, power lines, agricultural intensification, disturbance - all are identified in this plan as contributing to the loss of the species. The problem for us is that we do not know which of these is the most important influence, which the most urgent to tackle first, how much energy, time and money to direct at each. Any one of them might be exerting a decisive pressure but, since we do not know which, we must focus on all of them. If we do not, we risk everything.

But the Great Bustard can be saved in Morocco. This plan points the way with exemplary clarity and meticulous care. Everyone associated with its production deserves our thanks and praise. But the challenge is immense. It is as if we have to turn back the clock. The last areas where the Great Bustard survives need to be managed to replicate their condition half a century ago, before asphalt, cars, tractors, agricultural machinery, modern weapons and electricity made their way into the contemporary Moroccan landscape. These are the things that Wolfgang Gewalt was referring to when he said, with oblique irony, 'there is a lot we must not do'. He also said, very simply, directly and truly - and I commend it as the guiding principle and dictum of the coming endeavour:

'Nothing is so essential to our bustards as peace, and still more peace'.

N.J. Collar, Chairman, IUCN Bustard Specialist Group

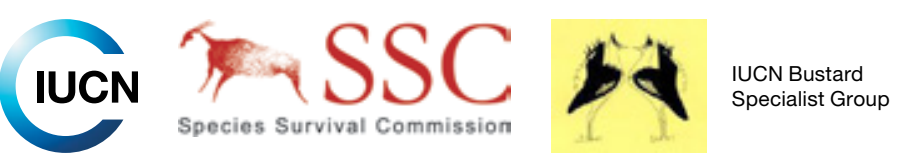




\section{Executive Summary}

The Moroccan population of the Great Bustard Otis tarda, a Vulnerable species according to the IUCN Red List of Threatened Species ${ }^{\mathrm{TM}}$, is small and declining, surviving mainly in two breeding areas (leks) and numbering some 40 to 50 birds. The population has a bleak outlook, which merits urgent conservation action. The main threats to this, the only population of Great Bustard in Africa, are collisions with power lines and other infrastructure, agricultural intensification, illegal hunting (or poaching), and different forms of disturbance, some of which have resulted in habitat fragmentation. Overall, factors affecting adult mortality are the most immediate and urgent threats to survival. Great Bustard conservation is also hampered by a number of constraints, such as inadequate designated status of core areas. The remaining strongholds are in Araoua and Tleta-Rissana, whilst other areas in northwest Morocco certainly used to support bustards until recently. In the early 2000s there were seven leks, in 2015 only two were found.

This plan is guided by a vision that by 2050 , the Moroccan population of the Great Bustard will be viable and have expanded into areas of its former range with a minimum of five successful leks, in harmony with the local socio-economic context and in accord with sustainable development. The goal is that by 2025, the key leks of Araoua and Tleta-Rissana will be safeguarded by appropriate national designations and strong community support, with the Great Bustard population increased to 80-100 birds and starting to expand to former areas, where appropriate conditions for recolonisation have been ensured.

In order to achieve this, six intervention strategies have been identified: establish surveillance capacity; minimise impacts from infrastructure; secure bustard habitat in key areas; strengthen awareness and valuation; research and monitoring; and sustainable financing. For each, a long-term objective and strategic objectives have been set, and prioritised actions prescribed to cover the period 2016-2025, with indications of responsibility and budget. Indicators and means of verifications have also been defined for each strategic objective in order to monitor implementation of the action plan and levels of attainment.

Implementation of the plan requires the urgent establishment of surveillance capacity backed up by measures to secure a traditional agricultural landscape within an appropriate site designation framework. The risk of collisions of bustards with power lines must be minimised, especially through underground cabling and marking, and poaching must be brought under control in order to cut out human-induced adult mortality. At the same time, bustards must have suitable habitat available throughout the year to enable them to successfully see through their unique and impressive annual cycle. Strong national cooperation and attention backed up by strategic international support are essential.

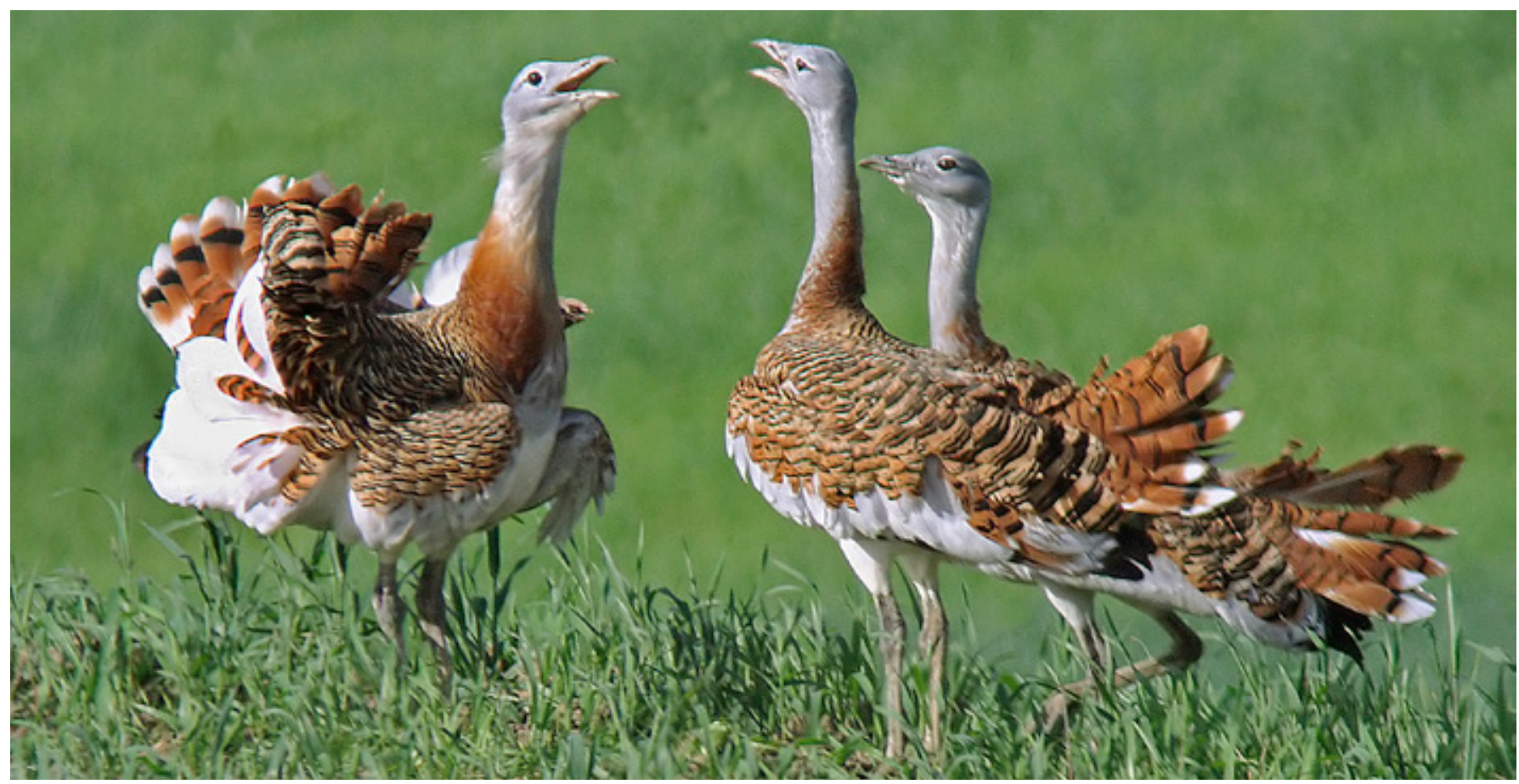

Three males of different ages at Laquessiba, Chekbouchan lek in 2005 (photo @ Carlos Palacín). 


\section{Introduction}

\subsection{The Great Bustard}

The Great Bustard Otis tarda (Linnaeus, 1758) is a Vulnerable species (BirdLife International 2013) with a wide range from Iberia and northwest Morocco in the west to China in the east. There are two subspecies: O. t. tarda, which extends from Iberia and north Morocco through central and southeast Europe to Turkey, Iran and east to Kazakhstan and central Siberia; and O. t. dybowskii, which occurs in southeast Russia, Mongolia and China. Asian populations are obligate winter migrants (Kessler 2013), whilst Eastern European populations migrate from Russia to wintering areas in South Ukraine (Watzke 2007). Western populations, including the northwest Morocco population are resident or partial migrants, showing a variety of migratory patterns across their Palaearctic range. Central European populations are facultative winter migrants in response to extreme weather (Streich et al. 2006); Iberian populations are partial and differential migrants by sex, with variable proportions of both sexes migrating according to sex-specific patterns (Alonso et al. 2000a, 2001 and 2009b; Morales et al. 2000; Palacín et al. 2009, 2011 and 2012).

Great Bustard is listed on Appendix I of the Convention on the Conservation of Migratory Species of Wild Animals (CMS, or Bonn Convention) and on Appendix II of the Convention on International Trade in Endangered Species of Wild Fauna and Flora (CITES) and the Convention on the Conservation of European Wildlife and Natural Habitats (or Bern Convention).

The Great Bustard world population was estimated in 2010 to be $44,100-57,000$ individuals, with about $60-74 \%$ occurring in Iberia (Alonso and Palacín 2010).

The Great Bustard was formerly widespread across this wide range, which has contracted significantly, resulting in a number of fragmented populations, some of which have disappeared (Palacín and Alonso 2008). Its status of Vulnerable is linked especially to this fragmented distribution and declines in a number of areas. For O. t. tarda, six demographically independent breeding populations are recognized in the Western Palearctic (Faragó 1986, Nagy 2009), as well as a population breeding from Southwest Russia through Kazakhstan to Northwest China:

- North African - Morocco

- Iberian - Spain, Portugal

- German-Polish Plain - Germany, Poland

- Carpathian basin - Austria, Czech Republic, Hungary, Slovakia, Serbia, Romania and Bulgaria

- Eastern European - European Russia, Ukraine

- Middle-East - Turkey (extending into west Iran)

\subsection{The Moroccan population of Great Bustard}

The Great Bustard is an endangered species in Morocco, historically restricted to three geographic divisions - the Tangier Peninsula, Rharb and Prérif (Thévenot et al. 2003). This population is the only African population of Great Bustard, which also represents the southern limit of the world breeding area (Alonso et al. 2005). All areas are in the northwest of the country, where seven leks (traditional places where males assemble during the mating season and engage in competitive displays that attract females) were identified in 2005 (Figure 1), when the population was estimated at 80-113 birds (Alonso et al. 2005).

Genetic studies indicate that the population in Morocco was colonised from Iberia thousands of years ago, with population declines and the barrier effect of the Gibraltar Straits favouring current genetic isolation; indeed, Morocco could be regarded as separate management unit, holding a significant proportion of the current genetic diversity of the species, which thus deserves urgent conservation measures (Alonso et al. 2009a). Complementary microsatellite analyses reveal the existence of three main genetic units corresponding to Morocco, the north-eastern part of Spain, and the rest of the Iberian Peninsula (Horreo et al. 2014).

\section{Legislation}

Under the provisions of the Dahir dated 21 July 1923 on the hunting policy, as amended, and of its implementing texts, it is illegal to capture, hunt or own the Great Bustard, which is listed as a protected species.

It is also listed in Category 2 under Law No. 29-05 on the protection and trade regulation of species of wild fauna and flora ("loi n 29-05 relative à la protection des espèces de flore et de faune sauvages et au contrôle de leur commerce").

Under the provisions of this Law, it is illegal to collect, without permission and by any means, specimens of such species from the wild. 
The Great Bustard population in Morocco is in decline, with annual estimates in the most northern leks decreasing from 99 birds in 1999 to 80 birds in 2005, and with the main threats identified as poaching, especially of males, collisions with power lines and agricultural intensification (Alonso et al. 2000 and 2005). It is forbidden by law to hunt this species in Morocco.

More details on the species' biology, distribution and habitats can be found in the status review document (available in French) accompanying this strategy report, entitled "La grande outarde (Otis tarda) au Maroc : État des connaissances sur l'espèce" (Qninba 2016).

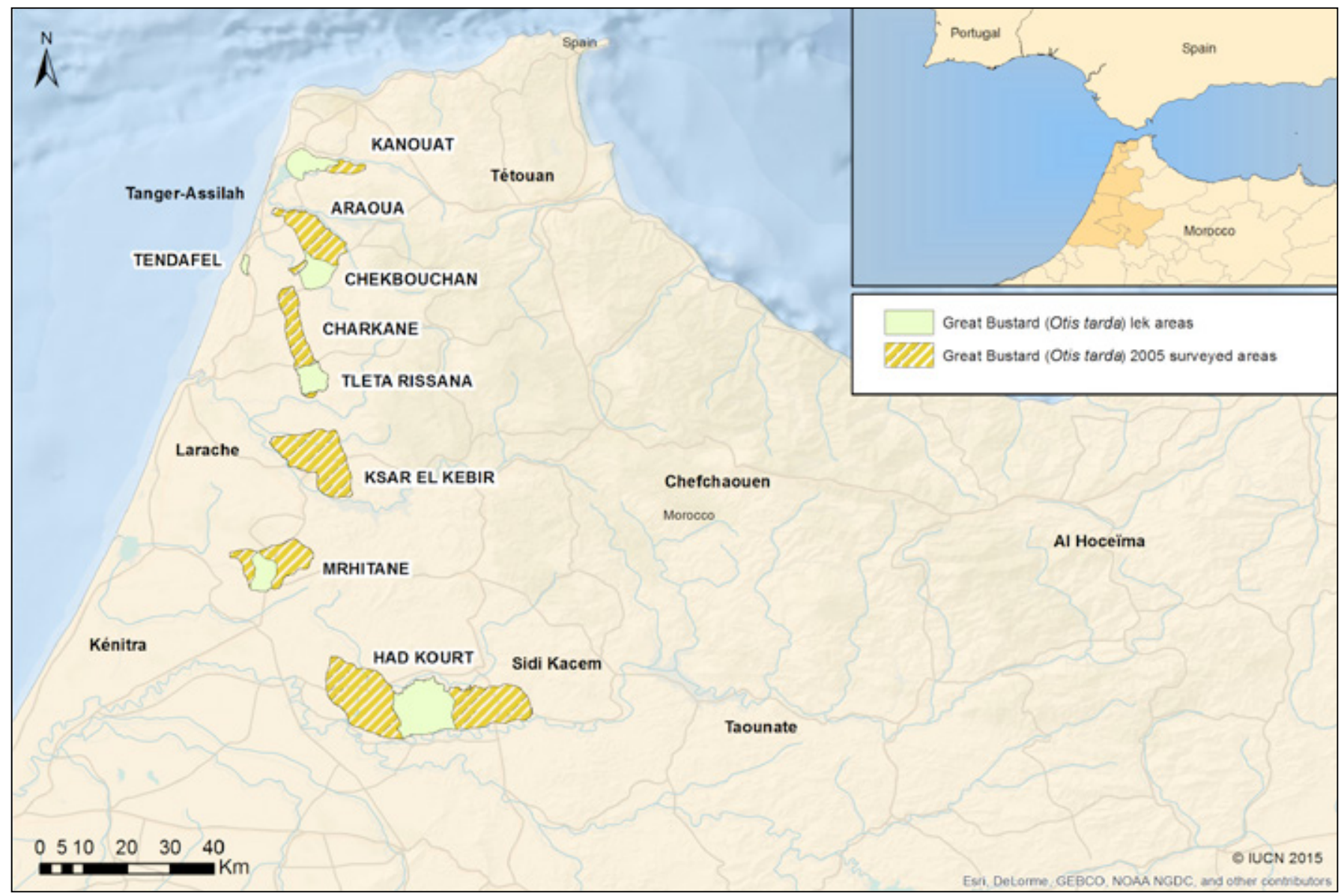

Figure 1. Great Bustard study area of 1999-2005 showing seven Great Bustard lek areas (light green patches) and two areas where bustards have been seen only in winter (Charkane) or occasionally reported (Ksar-el-Kebir) and the intensively surveyed areas (hatched) (Alonso et al. 2005). 


\section{Current Status of Great Bustard in Morocco (2015)}

\subsection{Numbers and distribution}

Great Bustard estimates have been derived from censuses carried out in Morocco in the springs of 1999, 2001, 2002, 2005 and 2015, giving a good indication of the size of the population over a 16-year period; further surveys were conducted in 2009, 2011 and 2014 (C. Palacín in litt. 2015) although results have not yet been published. Results of the censuses in 1999-2005 and 2015 are given in Table 1, which shows a summary of total birds estimated drawing on spring surveys and additional data, as well the total number of birds counted during the censuses; further details available in Alonso et al. (2005) and Alonso et al. (2015).

Additional censuses were conducted in 2003, 2004, 2006 and 2007 yielding total counts respectively of 45, 42, 60 and 77 birds (Arhzaf 2010) (these data are not shown in Table 1, which focuses on the total estimated population size). The dynamics and trend of the Moroccan Great Bustard population between 1999 and 2014 were studied by Palacín et al. (2016), who provide additional total counts of 49 birds in 2009, 41 in 2011 and 34 in 2014. During the census of the Moroccan population of Great Bustard on 9-13 March 2015 covering the seven previously identified lek areas, 40-44 bustards were found only in two areas - Araoua and Tleta-Rissana (Figures 2 and 3), although all previous lek areas were visited, resulting in a new population estimate of $45-50$ birds (Alonso et al. 2015). Of birds located, 11 were males and 29-33 were females.

Table 1. Summary of estimates of Great Bustards in Morocco derived from spring censuses and additional information; census results are shown in standard font whilst estimated figures are in italics and bold (after Alonso et al. (2005) and Alonso et al. (2015). The figure of 90 under 'Total in census' for 1999 is from a count by Hellmich and Idaghdour (2002) in December 1998.

\begin{tabular}{|l|c|c|c|c|c|}
\hline Leks & $\mathbf{1 9 9 9}$ & $\mathbf{2 0 0 1}$ & $\mathbf{2 0 0 2}$ & $\mathbf{2 0 0 5}$ & $\mathbf{2 0 1 5}$ \\
\hline Kanouat & 14 & 8 & $\mathbf{8}$ & 5 & 0 \\
\hline Araoua & 26 & 26 & $\mathbf{2 6}$ & 16 & 42 \\
\hline Chekbouchan & $\mathbf{1 3}$ & $\mathbf{1 3}$ & 16 & 15 & 0 \\
\hline Tendafel & 24 & 27 & 23 & 17 & 0 \\
\hline Tleta-Rissana & $\mathbf{1 0}$ & 12 & 6 & 17 & 3 \\
\hline Mrhitane & $\mathbf{6}$ & $\mathbf{6}$ & $\mathbf{6}$ & $\mathbf{6}$ & 0 \\
\hline Had-Kourt & 6 & 6 & $\mathbf{5}$ & $\mathbf{4}$ & 0 \\
\hline Total in census & $70-90$ & 84 & 76 & 71 & $40-44$ \\
\hline Total estimated & $\mathbf{9 9}$ & $\mathbf{9 8}$ & $\mathbf{9 0}$ & $\mathbf{8 0}$ & $\mathbf{4 5 - 5 0}$ \\
\hline
\end{tabular}

\subsection{Status}

The census results paint an alarming picture of decline in both numbers and range, especially between 2005 and 2015. This represents a decline of at least $40 \%$ over 10 years, confirming the critical conservation status of the Great Bustard in Morocco, noting also a sex ratio of around 1 male to 3-4 females and, more positively, a high productivity year in 2014 (Alonso et al. 2015). The decline based on actual counts may be as high as 55\% between 1999 and 2015, or $62 \%$ between 1999 and 2014. Palacín et al. (2016) estimate that the population could become extinct in about 20 years if present threats remain.

The declining trend in numbers is illustrated in Figure 4, showing a steep trend line, which, if allowed to continue, will clearly spell the end of this population within a short time frame. The apparent loss of up to five occupied leks between 2005 and 2015 is also of major concern. Whilst it is possible that bustards still utilise some of these areas, it seems likely that they no longer function as leks. This situation could be reversible, at least for some areas, leaving two population challenges - one to increase the population size, the other to encourage recolonisation of former leks. Both are needed for the status of Great Bustards in Morocco to improve and for the population to sustain itself into the future. 


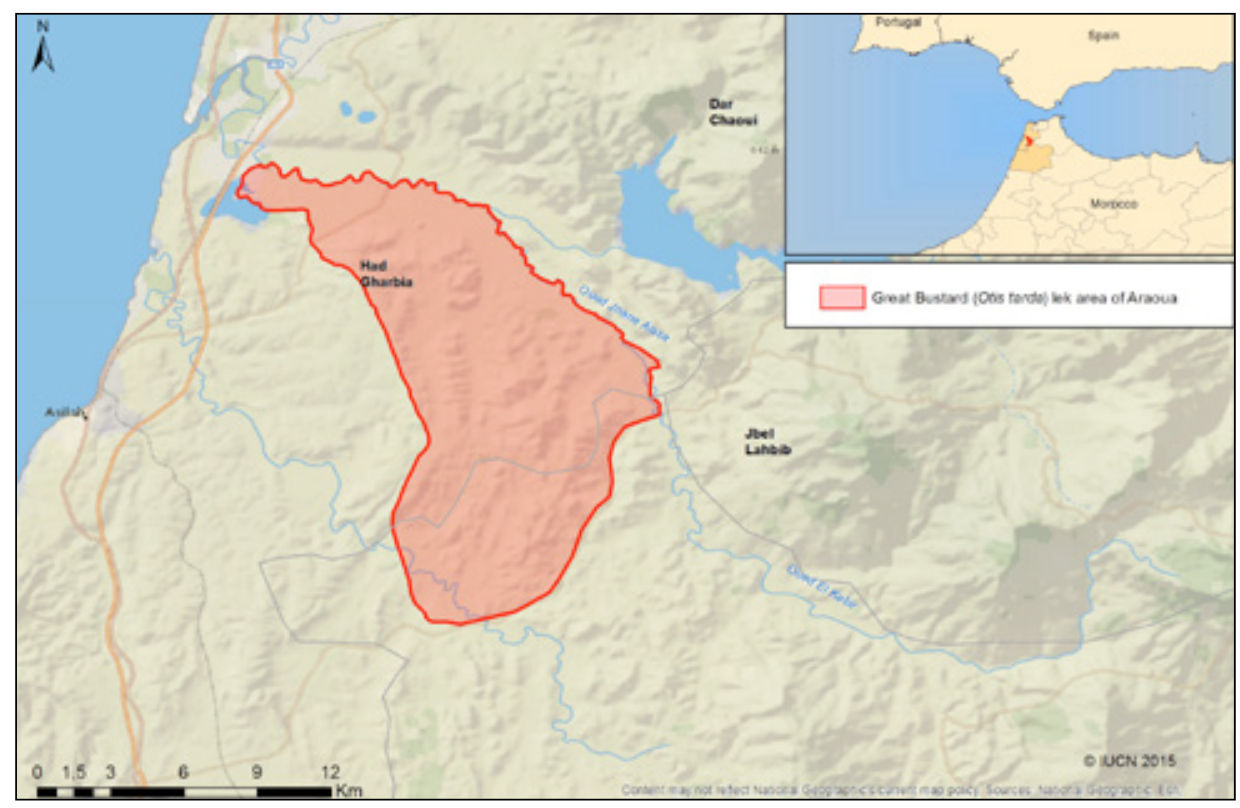

Figure 2. Boundary of the Great Bustard lek area of Araoua (adapted from Google Earth map produced by C. Palacín for Alonso et al. 2015).

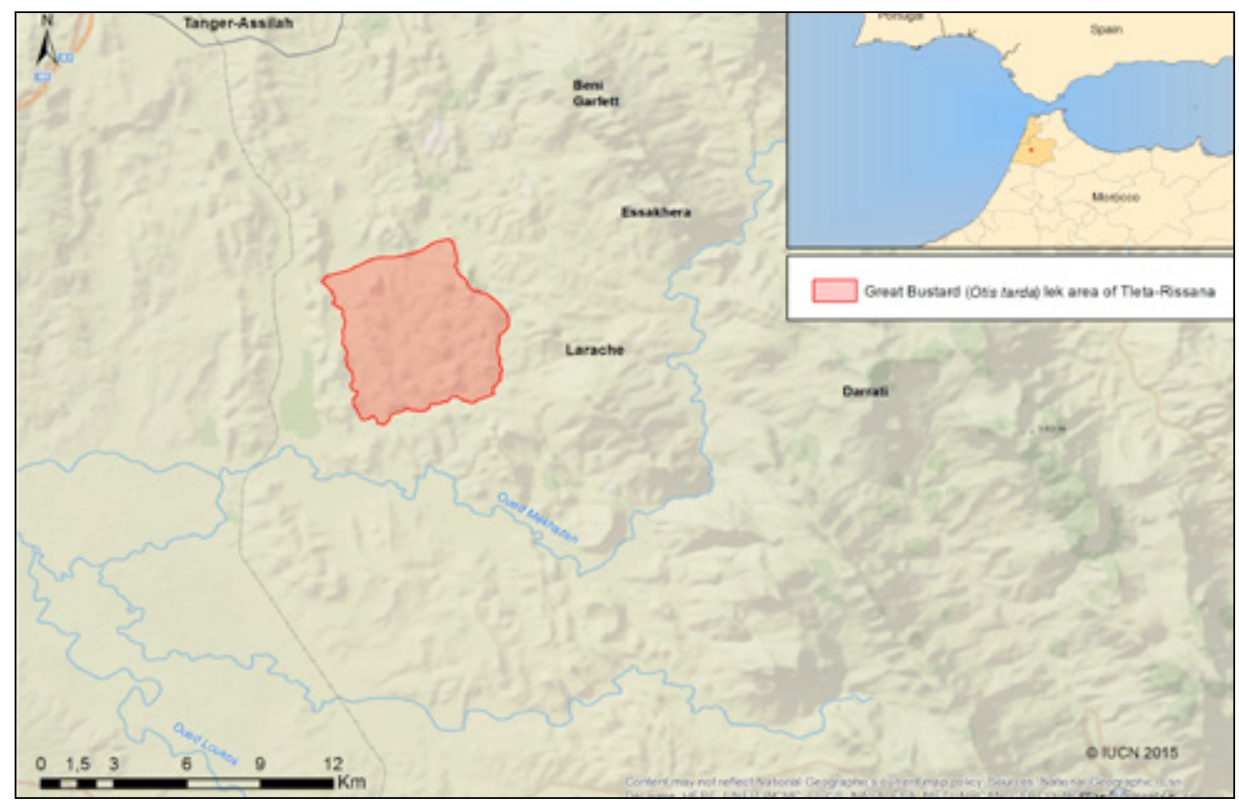

Figure 3. Boundary of the Great Bustard lek area of Tleta Rissana (adapted from the Google Earth map produced by C. Palacín for Alonso et al. 2015).

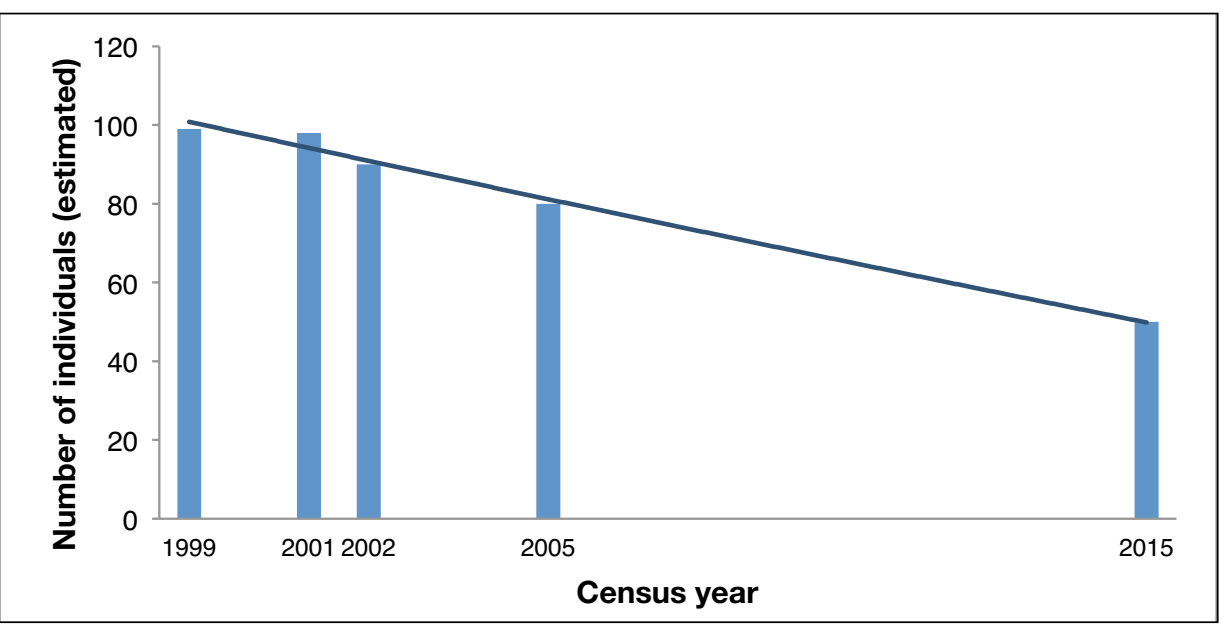

Figure 4. Estimates of the Great Bustard population in Morocco from five censuses carried out between 1999 and 2015, with trend graph shown; based on data in Alonso et al. 2005 and Alonso et al. 2015. 


\section{Threat Analysis}

Great Bustards in Morocco are prone to a number of threats, of which the direct threats on adult mortality are the most severe. Threats have been described and detailed by Hellmich and Idaghdour (2002), Alonso et al. (2005), Arzahf (2010) and Qninba (2016), and were also listed and ranked by the stakeholder workshop participants. In addition, Palacín et al. (2016) analysed the growth in infrastructure between 2005 and 2014. Full accounts of threats are thus not given below, rather an overview of threats to guide the development of the action plan. The threats described below are based on all these sources and on information collected during the action plan development mission of March 2015, as well as on 2015 census results (Alonso et al. 2015).

\subsection{Direct and Indirect Threats}

Alonso et al. (2015) consider that adult mortality represents the main threat to the Great Bustard population in Morocco, and thus any human-induced adult mortality cause should be eliminated. The main threats and potential threats identified in September 2014 by participants of the Stakeholder Strategy Development Workshop and through the 2015 census fieldwork and interviews and site visits in March 2015 are as follows:

- Poaching / illegal hunting, especially of males

- Breeding males are magnificent, and thus a highly prized hunting trophy.

- Breeding males are also especially vulnerable during the courtship period, when they display in open areas.

- The imbalanced sex ratio of the population is an indication of targeted male hunting.

- Local people report incidences of hunters coming to look for Great Bustards.

- Collisions with power lines

- Great Bustards are prone to collisions due to their reduced frontal vision angle and relatively low manoeuvrability.

- Arhzaf (2010) reports of seven cases of Great Bustard collisions in Morocco, mostly with power lines.

- This is the main cause of bustard mortality in parts of Spain (Alonso et al. 2003. Martín et al. 2004, Palacín et al. 2004), Austria and Hungary (Raab et al. 2012). A new power line in Spain killed at least 25 Great Bustards in an $8.5 \mathrm{~km}$ long sector of line in one year (C. Palacín, in litt. 2015).

- Power lines already cross Great Bustard areas in Morocco, including across valleys close to principal leks. Palacín et al. (2016) report on seven new power lines totalling $19 \mathrm{~km}$ between 2005 and 2014 in Kanouat and Araoua lek areas.

- No power lines in Morocco carry markers.

- Since 2005, hundreds of new power lines have been installed under the global rural electrification programme in the provinces of Morocco where

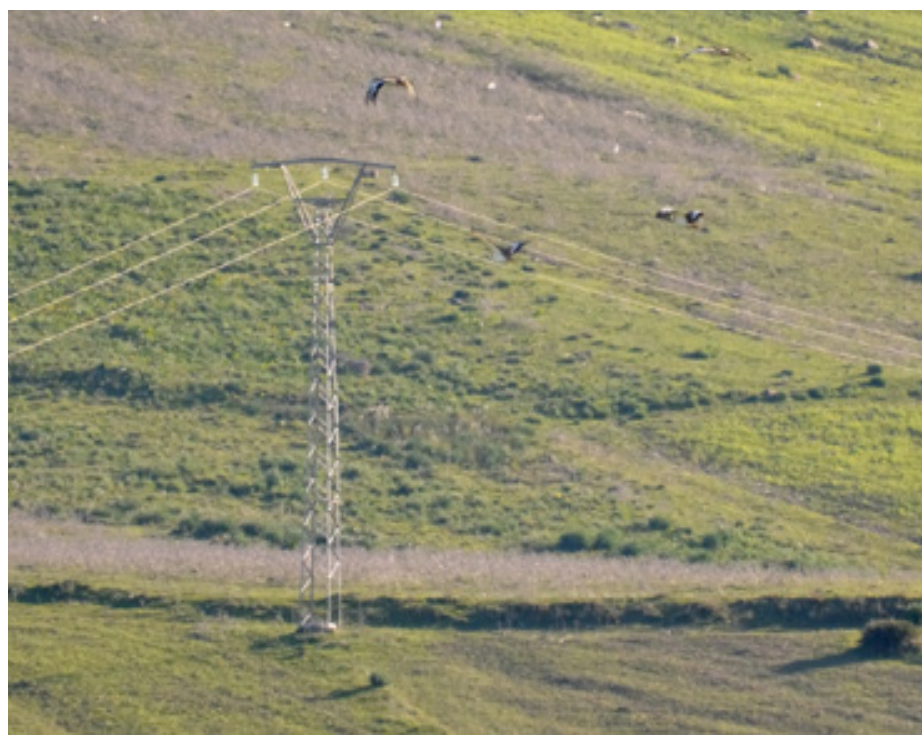

Great Bustards flying over a power line in Araoua; this power line crosses a valley through which bustards must pass frequently (photo @ Rachid El Khamlichi). 
- Agricultural intensification, including use of chemicals

- Great Bustards cannot survive in an intensively managed agricultural landscape, especially large expanses of monoculture, where there is the added threat of mechanical harvesting. Palacín et al. (2016) recorded 39 new farms in lek areas between 2005 and 2014, including 18 in Araoua.

- Some parts of their former range have seen significant agricultural developments.

- The heavy use of chemicals (fertilizers, herbicides, insecticides) would no doubt have an impact on Great Bustards, most likely on the productivity; bustard chicks / young are partially reliant on an invertebrate diet.

- Loss of habitat

- Loss of habitat is largely due to agricultural intensification.

- A particular threat is the loss of natural cover. Cover is likely to be in very short supply after harvest of crops in the summer.

- Some areas in the north of the bustard's range have been impacted by urban development, e.g. Tangier airport and an area set aside for sewage treatment.

- Infrastructure developments (road, rail, etc.)

- The Great Bustard's range in Morocco falls between Tangier and Meknès, and is traversed already by national roads, a motorway and railway. There is good evidence that Great Bustards avoid roads and other sources of disturbance (Lane et al. 2001).

- Currently, a new high-speed rail line is being constructed.

- High-speed railways can kill bustards, whilst road/rail construction causes permanent habitat loss as bustards tend to avoid them, with a threshold distance of about $750 \mathrm{~m}$ (Torres et al. 2011).

- Their development is also associated with clearance of habitat, erection of power / other lines along their routes and cutting up of landscapes, often leading to further impacts.

- Transport line increases between 2005 and 2014 within lek areas include $10 \mathrm{~km}$ of highway, $2 \mathrm{~km}$ of high-speed train line and $33.2 \mathrm{~km}$ of rural roads (Palacín et al. 2016).

- Disturbance and destruction of nests and chicks

- As Great Bustards nest in farmland, inevitably they will experience some measures of disturbance.

- Trampling of nests by livestock is also a potential threat, as is early mechanised crop harvesting.

- Disturbance/predation of dogs may constitute a threat, especially to eggs and chicks. Although Great Bustards and shepherds and their dogs have co-existed for hundreds of years, feral dogs appear to be widespread (and possibly increasing) in parts of the Great Bustard's range.

- The potential impact of natural predators, such as foxes, is unknown.

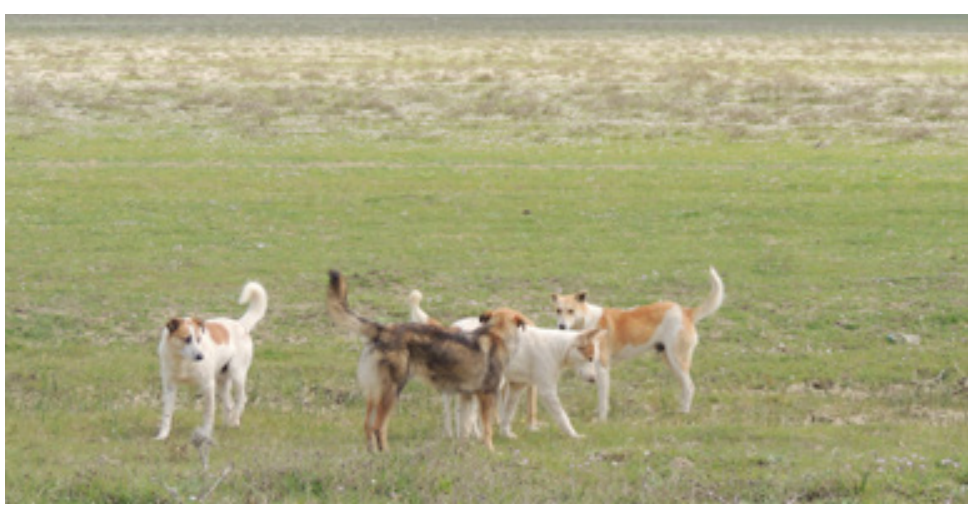

A pack of loose or feral dogs in Araoua (photo (c) Tim Dodman).

These threats are illustrated in the following problem trees (Figures 5 and 6).

Overarching factors include climate change and development in northern Morocco, with an increasing human population exerting greater environmental pressures in the rural landscape. These are also driving factors for most threats listed but it is not realistic to mitigate climate change or human population growth within a species action plan. 


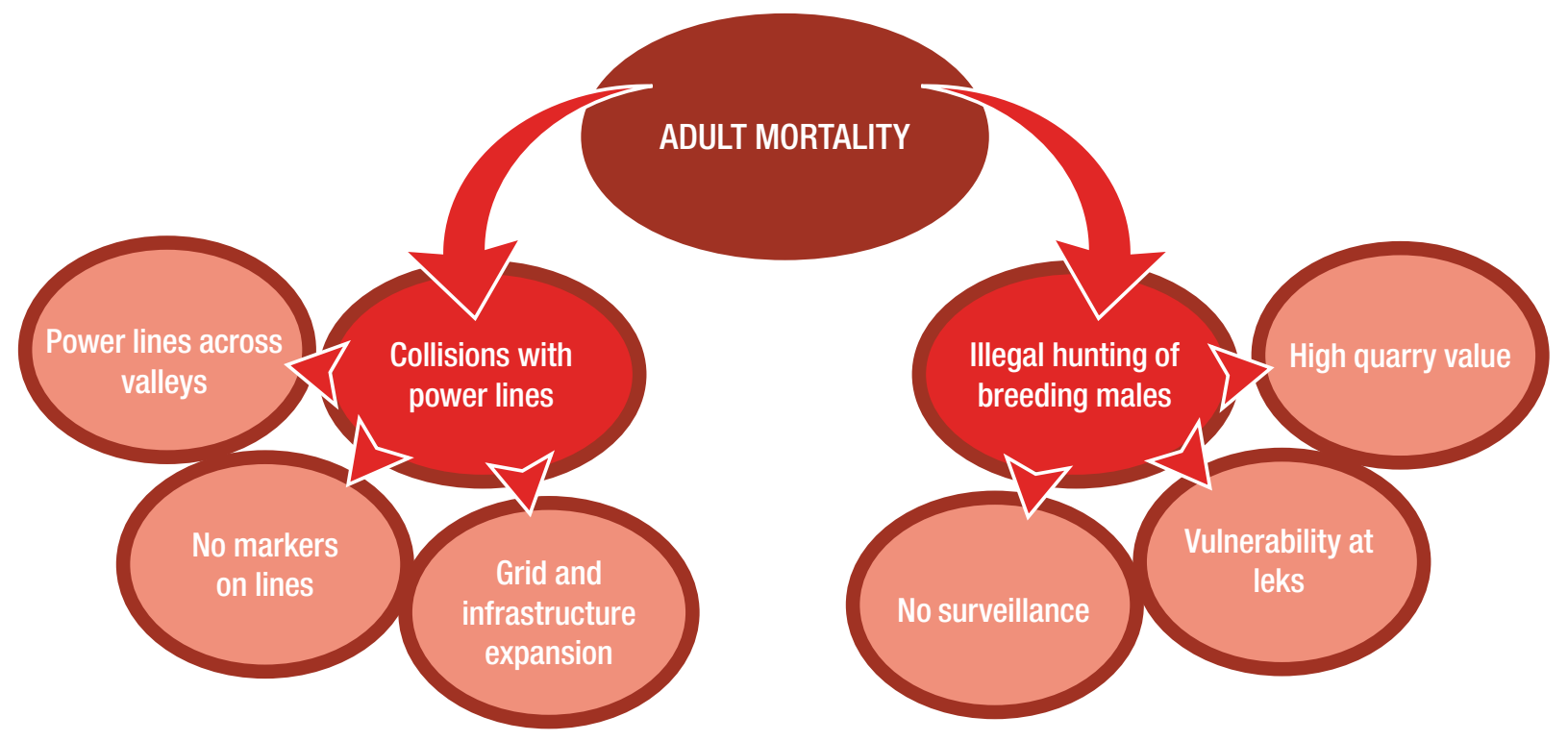

Figure 5. Problem tree analysis: Threats causing adult mortality.

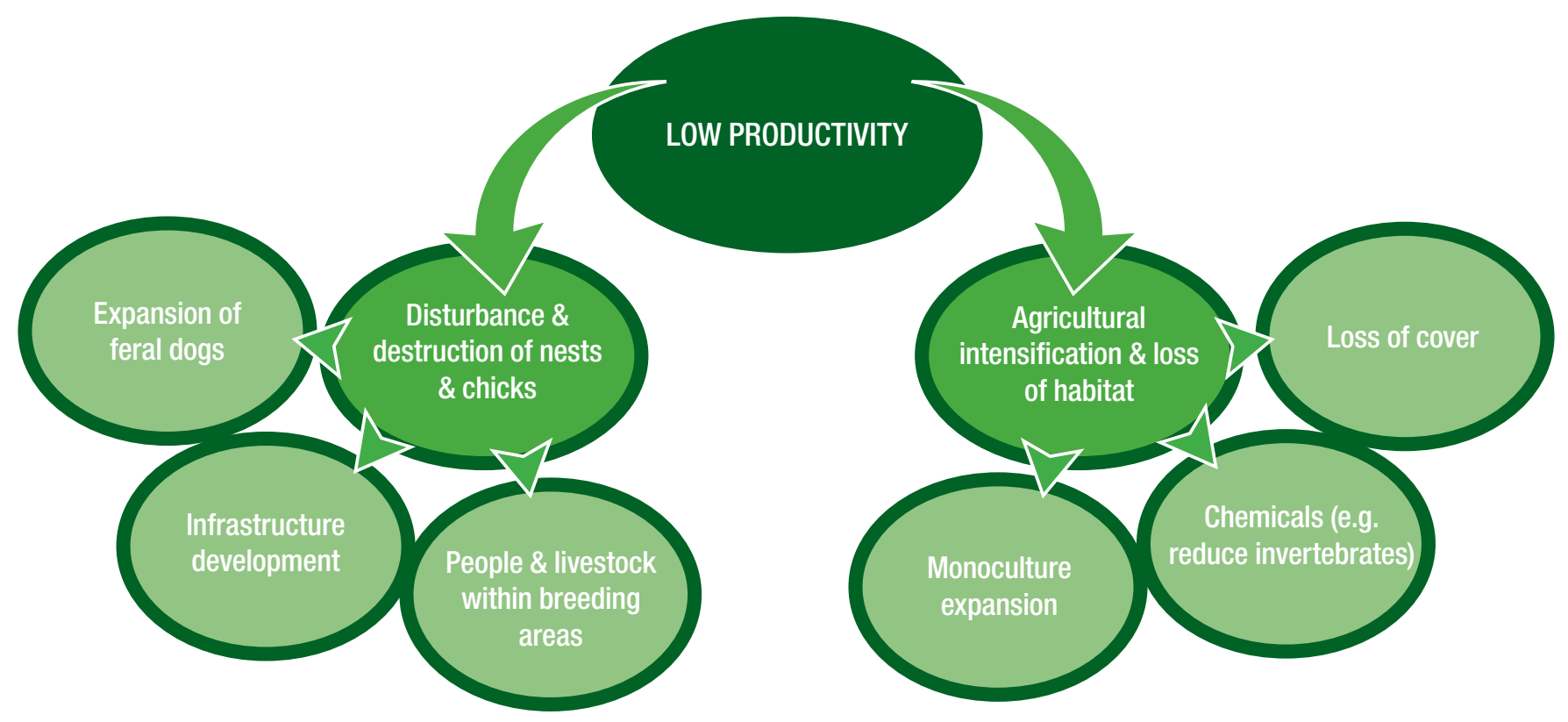

Figure 6. Problem tree analysis: Threats causing low productivity. 


\subsection{Constraints}

In addition to these direct and indirect threats, a number of constraints to Great Bustard conservation in Morocco have been identified. These are factors that may influence the capacity and/or the willingness to address the threats; or they may be precursors required for reducing threats. The principal identified constraints are given below, and summarised in Figure 7:

- Limited integrated planning for the conservation, monitoring and research of the Great Bustard and its habitat

- Although threats have been identified over the years, there has been no consistent conservation planning for the Great Bustard in Morocco. However, the need for such planning has been identified, and should be addressed by the adoption and implementation of this plan.

- No Great Bustard areas are protected, despite the rarity of the species.

- Censuses during the courtship season have been carried out regularly since 1999, although results between 2005 and 2015 are not yet widely available.

- Weak or absent protection of current and recently abandoned lek areas

- Some areas have been designated as Sites d'Intérêt Biologique et Écologique (SIBEs, Sites of Biological and Ecological Interest), whilst Great Bustards occur at times in some floodplain areas of the Complexe du Bas Tahaddart Ramsar Site (Dakki et al. 2011). However, these designations do not adequately cater for priority bustard areas, nor do they carry sufficient weight to afford meaningful site protection measures.

- Irregularity of scientific research with a focus mainly on breeding season

- Apart from winter/early spring censuses, no regular research is carried out, and knowledge about bustard status outside the (early) breeding season is limited.

- Limited means (human and financial) available for Great Bustard conservation

- Resources have been available in the past for some conservation activities, mainly as a result of past road developments. However, no government funds have yet been set aside for Great Bustard conservation, nor external donors identified.

- The support of the current planning process presents a fresh opportunity to mobilise resources.

- There are no personnel within government or civil society sectors currently engaged in Great Bustard on a regular basis.

- Poor coordination between government sectors

- As the Great Bustard lives largely in agricultural areas, different government sectors need to be engaged in conservation activities and designations.

- Limitations of Environmental Impact Assessments (EIAs)

- Infrastructural developments do not tend to take the Great Bustard into proper consideration during the planning and development stages.

- Low level of awareness about the critical status of bustards in Morocco

- There is low awareness about the critical status of the Great Bustard in Morocco at the local level and within other circles.

- Low economic value attributed to the Great Bustard

- The population of the Great Bustard is far too small to allow the valuation of the species through hunting. Moreover, it is illegal to hunt the Great Bustard in Morocco.

- Earnings that may be derived from the development of tourism-based activities in connection with the Great Bustard seem very limited, although this option may be explored during the implementation of this plan.

- Difficulty to breed Great Bustards in a captive setting

- There is an interest within some sectors for captive rearing of Great Bustards, but past efforts elsewhere have demonstrated that this is not at all easy, would be extremely expensive and offers no guarantee of successful reintroduction in the future.

Several threats and constraints are closely linked and overlapping. 


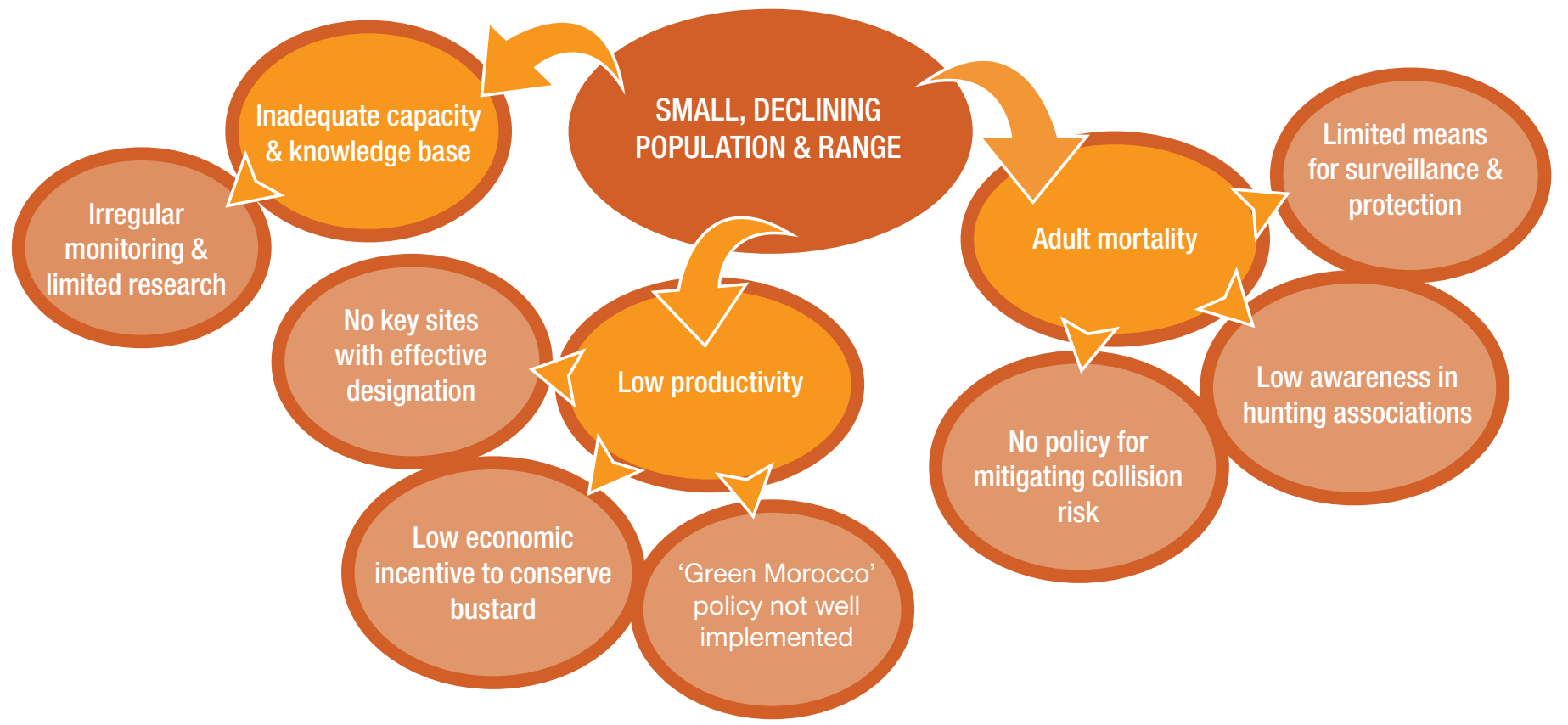

Figure 7. Problem tree analysis: Constraints contributing to the small, declining population and range status of the Great Bustard in Morocco.

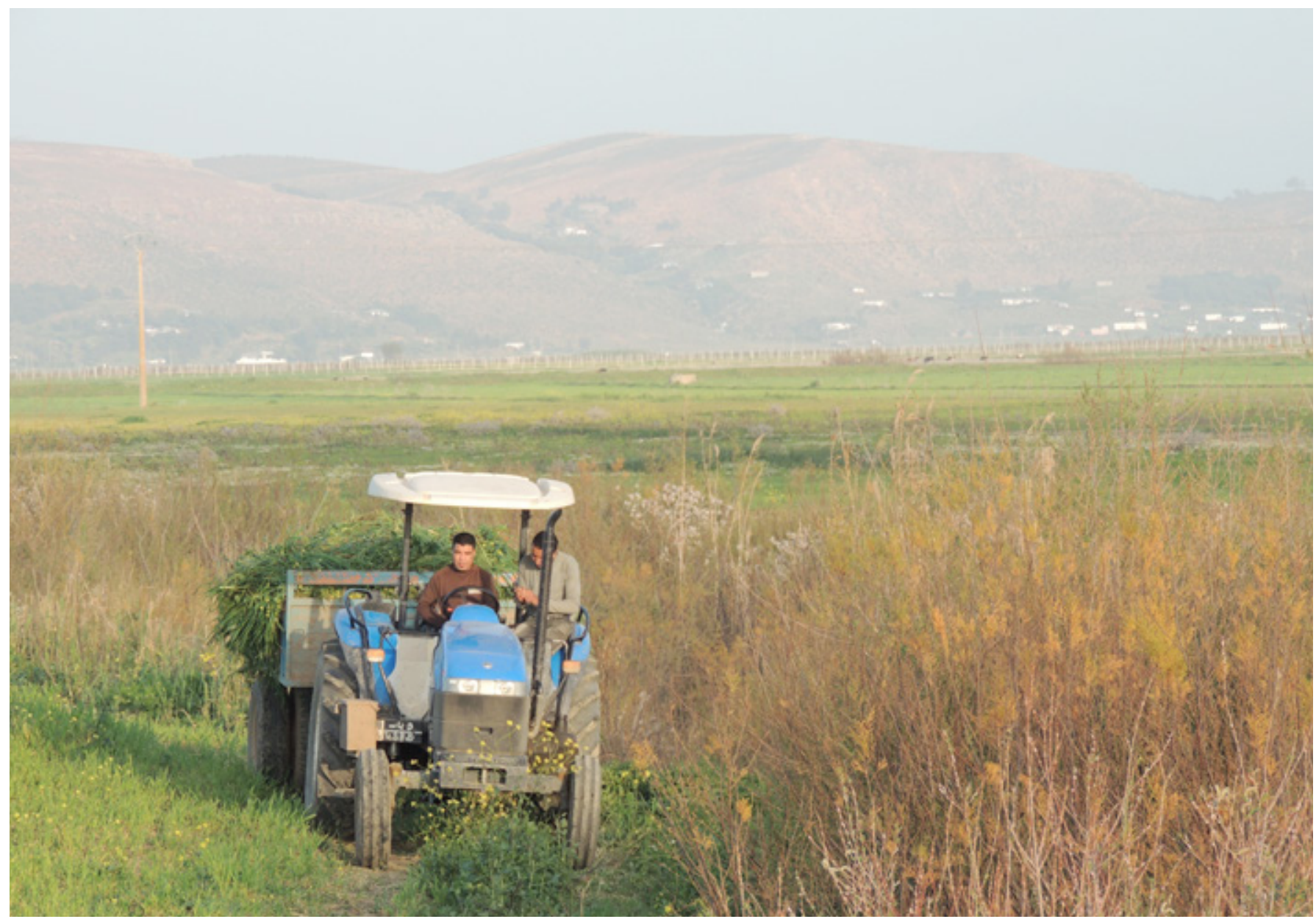

Early harvest in areas where bustards breed has been recorded as a threat (Arhzaf 2010), one aspect of agricultural intensification, which has a landscape-wide impact (photo () Tim Dodman). 


\subsection{Threat Ranking}

Threat ranking was not carried out in detail during the Stakeholder Workshop of September 2014, but separate groups clearly identified the main threats as illegal hunting and collisions. Information from the workshop and references combined with information collected during interviews conducted in March 2015 results in the threat ranking below (Table 2), which follow the format of an Important Bird and Biodiversity Area (IBA) form of BirdLife International. Note that the combined score is not a standard means of IBA threat ranking.

Table 2. Great Bustard Threat Ranking, Morocco

\begin{tabular}{|c|c|c|c|c|c|}
\hline \multirow[b]{2}{*}{ THREAT TYPES } & \multicolumn{3}{|c|}{ Score } & \multirow{2}{*}{ 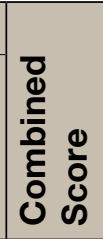 } & \multirow[b]{2}{*}{ Details } \\
\hline & 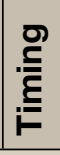 & $\begin{array}{l}\text { ¿ } \\
\text { ¿ } \\
\text { c }\end{array}$ & 嫈 & & \\
\hline \multicolumn{6}{|l|}{ Factors causing adult mortality } \\
\hline Collisions with power lines & 3 & 3 & 3 & 12 & $\begin{array}{l}\text { Rarely recorded, but certainly } \\
\text { significant and expanding }\end{array}$ \\
\hline Poaching / illegal hunting, especially of males & 3 & 2 & 3 & 9 & $\begin{array}{l}\text { Significant even if } 1 \text { adult male per year } \\
\text { is hunted }\end{array}$ \\
\hline \multicolumn{6}{|l|}{ Factors causing low productivity } \\
\hline $\begin{array}{l}\text { Habitat loss and modification: infrastructure } \\
\text { development (roads/railways), urban expansion }\end{array}$ & 3 & 2 & 2 & 7 & $\begin{array}{l}\text { Current threat with potential long-term } \\
\text { impact }\end{array}$ \\
\hline \multicolumn{5}{|l|}{ Agricultural intensification, including use of chemicals } & Split into sub-threats below \\
\hline Small-holder farming & 3 & 2 & 0 & 3 & Widespread but not severe \\
\hline Agro-industry farming & 3 & 2 & 3 & 9 & High threat on landscape scale \\
\hline Livestock farming and ranching (small-holders) & 3 & 3 & 0 & 3 & Widespread but not severe \\
\hline $\begin{array}{l}\text { Disturbance and destruction of nests and chicks, } \\
\text { including potential predation (e.g. by dogs) }\end{array}$ & 3 & 2 & 1 & 5 & Hard to quantify / measure \\
\hline Tourism and recreation areas & 2 & 1 & 0 & 2 & Unlikely to have an impact \\
\hline \multicolumn{6}{|l|}{ Overarching threats } \\
\hline Climate change & 1 & 2 & 1 & 3 & Potential impacts need investigation \\
\hline
\end{tabular}

\section{Timing of selected threat}

Happening now

Likely in the short term (within 4 years)

Likely in the long term (beyond 4 years)

Past (unlikely to return) and no longer limiting

\section{Scope of selected threat}

Whole area or bird population (>90\%)

Most of area or bird population (50-90\%)

Some of area or bird population (10-50\%)

Small area or few individual birds $(<10 \%)$
Timing score

3

2

1

0

Scope score

3

2

0

\section{Severity of selected threat}

Rapid deterioration (>30\% over 10 years or 3

Severity score

3 generations whichever is longer)

Moderate deterioration (10-30\% over 10 years or 3 generations)

Slow deterioration (1-10\% over 10 years or 3 generations)

No or imperceptible deterioration ( $<1 \%$ over 10 years) 
The analysis based on timing, scope and severity indicates that collisions with power lines are the most significant threat to Great Bustards in Morocco, followed by illegal hunting and agricultural intensification on a more 'industrial' scale, i.e. the development of monoculture, as is happening particularly in the south of the bustard's range, then habitat loss and modification. These landscape threats combined are likely to be more important nowadays than illegal hunting. Disturbance is the next most significant threat, due both to disturbance of breeding birds and ongoing infrastructural developments.

Note that some threats are more expected than proven or are at least hard to quantify, such as disturbance and predation, whilst the direct impacts of climate change have not been studied.

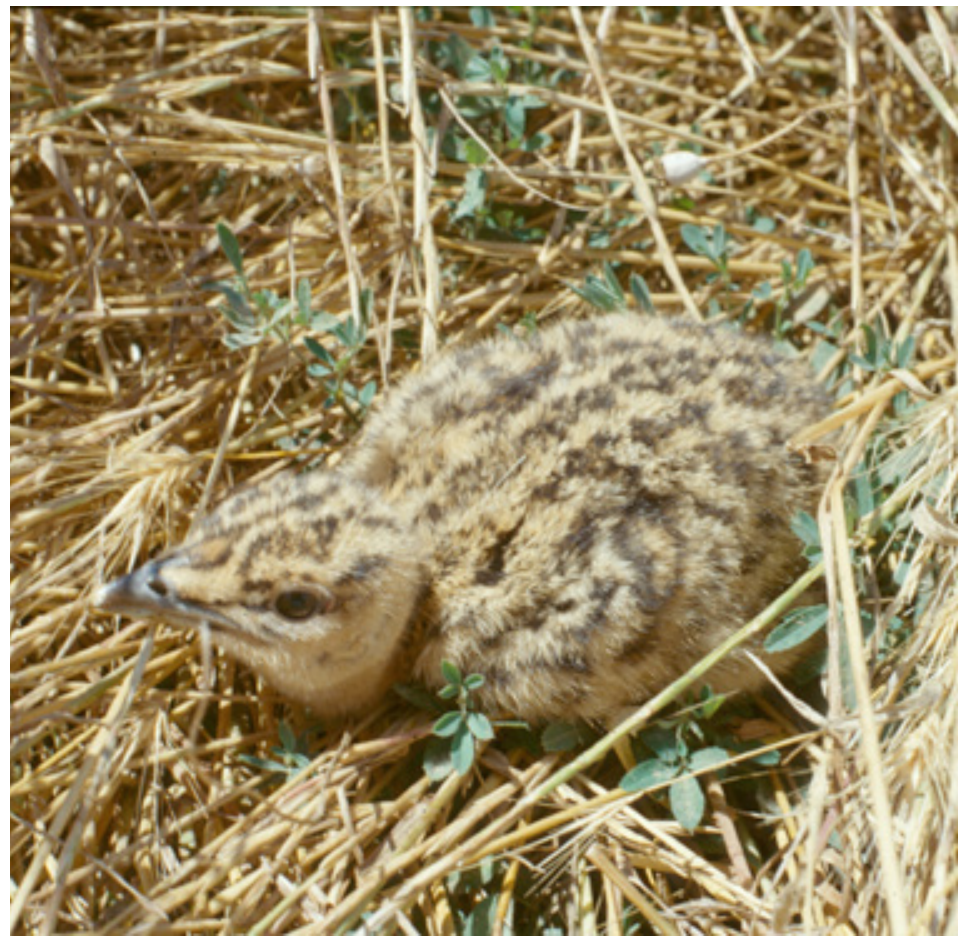

Bustard chick (photo @ Carlos Palacín)

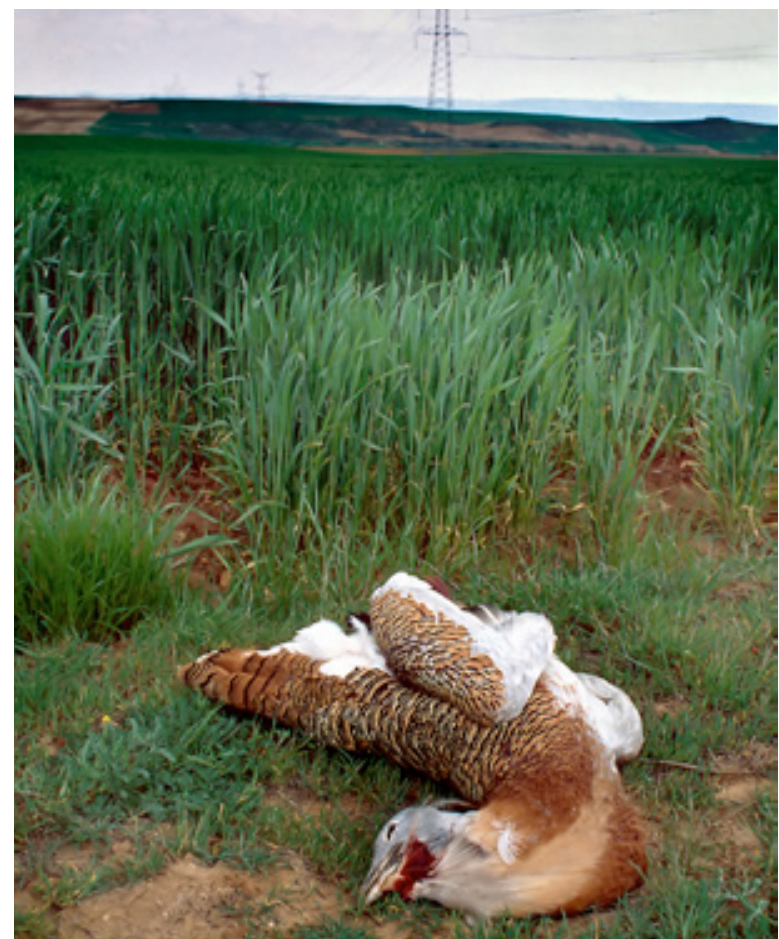

Male victim of a collision with a power line in Spain (photo @ Carlos Palacín)

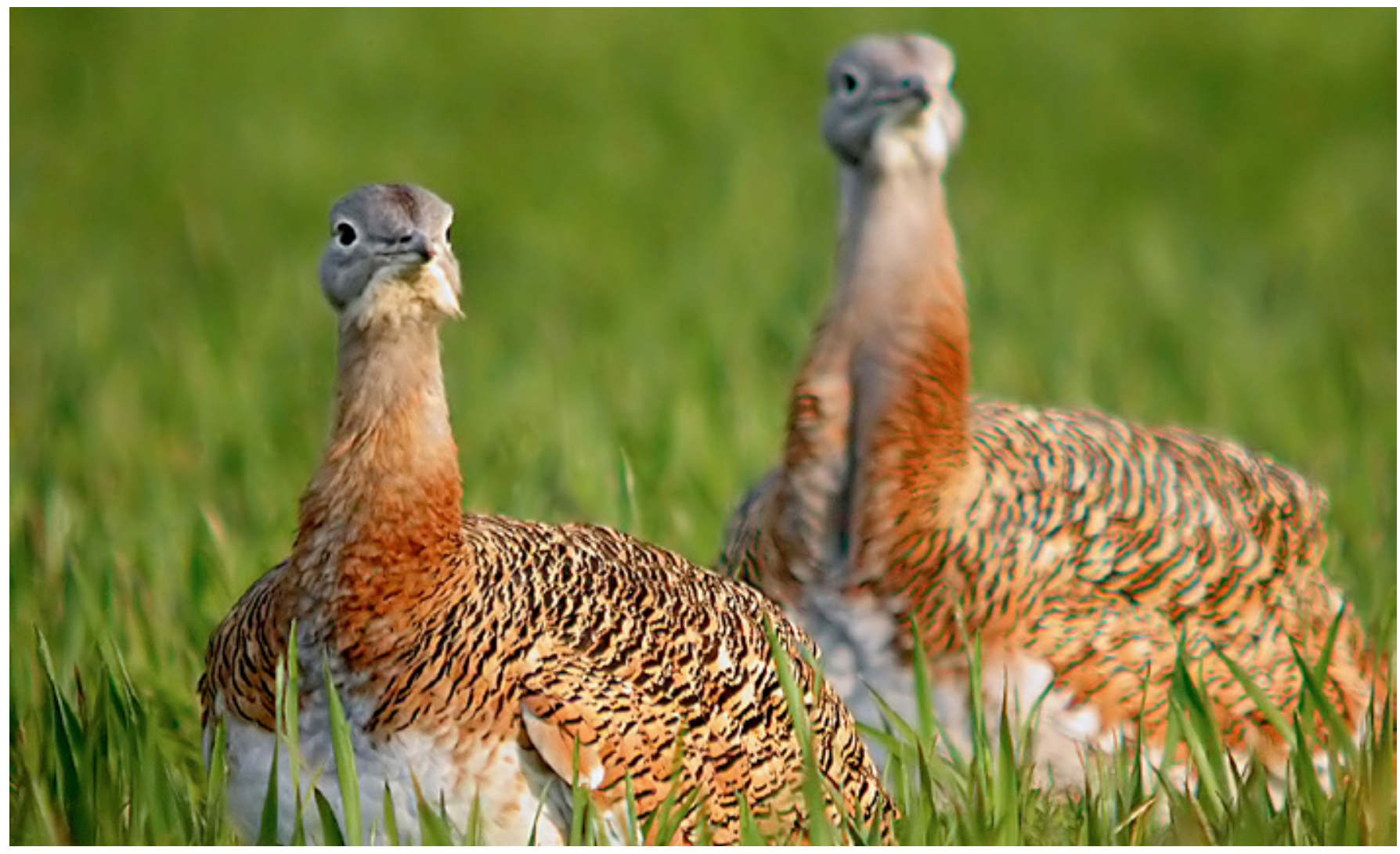

Two female bustards (photo @ Carlos Palacín) 


\section{Conservation Strategy}

It is clear from the threats outlined above and the dwindling population size that urgent conservation measures are needed to prevent the extinction of the Great Bustard in Morocco, and indeed in Africa. Alonso et al. (2015) point out that numbers of Great Bustards in Morocco are similar to the minimum numbers reached in Germany and Austria in the 1990s, indicating that extinction could theoretically be avoided in Morocco, provided the necessary conservation measures are urgently implemented. The following Vision and Goal ${ }^{1}$ are based on statements developed by the stakeholder workshop participants, but updated in light of the 2015 census, which found bustards in only two leks, as opposed to seven in 2005.

\subsection{Vision}

By 2050, the Moroccan population of the Great Bustard will be in a healthy, secure and viable state, and have expanded into areas of its former range with a minimum of five successful leks, in harmony with the local socio-economic context and in accord with sustainable development.

\subsection{Goal}

By 2025, the key leks of Araoua and Tleta-Rissana will be protected by appropriate national designations and strong community support, with the Great Bustard population increased to 80-100 birds and starting to expand to former areas, where appropriate conditions for recolonisation have been ensured.

\subsection{Intervention Strategies}

In order to meet the vision and goal, and based on the threat analysis, intervention strategies and objectives are needed, supported by short-term, medium-term and long-term activities. The following intervention strategies have been identified, whilst proposed activities are outlined in the next section:

- Establish surveillance capacity

- Minimise power line collisions and impacts from other infrastructure

- Secure bustard habitat in key areas

- Strengthen awareness and valuation

- Research and monitoring

- Sustainable financing

\subsubsection{Strategy 1 - Establish surveillance capacity}

The Moroccan population of Great Bustard is most vulnerable to adult mortality (Alonso et al. 2015). In order to address this, the birds need some measure of protection. The Great Bustard is a protected species in Morocco (Hellmich \& Idaghdour 2002), but its main areas are not protected. Thus, the most effective immediate means of protection should be to take measures to prevent mortality of the birds, whilst other measures (such as establishing some kind of protected area) are likely to take longer to achieve.

All respondents to interviews considered that surveillance was paramount and that guards / guardians or écogardes should be employed to protect the remaining bustards. Surveillance cuts across all actions, as it involves building a local team, which would be responsible for managing and implementing the action plan on a day-to-day basis. Different mechanisms were proposed for putting in place a guardian system, with the following options possible:

- Uniformed guards employed by HCEFLCD

- Uniformed guards employed by civil society, e.g. GREPOM

- Uniformed guards employed by the Fédération Royale Marocaine de Chasse (Royal Moroccan Hunting Federation) in the framework of their amodiation

- Local shepherds serving as informers

${ }^{1}$ An overarching Vision is an inspirational and relatively short statement that specifies the desired status of a species (including range, ecological role and relationship with humans) over a given period (which should be long-term, typically 30-40 years). A Goal describes what can be realistically achieved in the medium-term (typically 5-10 years). 
The main role of guardians would be to monitor and protect bustards, especially from hunters, and especially during the courtship and breeding season, focusing on leks. Guardians could keep records of observations and numbers of birds and GPS locations of all observed individuals. They should also monitor mortality at the most dangerous power lines through casualty transects, after training by specialists. Undoubtedly the presence of guards would also give out a strong awareness message, and people would know that protection measures were in place; the employment of locals as guardians would further demonstrate a local economic benefit.

Guardians would invariably need some resources to enable them to monitor bustards and watch out for any potential activity detrimental to them. Respondents made different suggestions, but some means of transport and communication (mobile phones) were deemed essential, whilst other attributes could include binoculars, telescope / tripod, uniform and boots.

Putting a guardian system in place would invariably involve coordination. There were suggestions to establish a Great Bustard centre or office, staffed by a project coordinator and assistant. This centre would serve as a focal point for the guardians and for all bustard conservation activities; it could also have displays and other awareness materials. Guardians would also need to be trained.

A guardian system is working well around the Souss-Massa National Park, which is crucial for the conservation of the last viable wild population of Northern Bald lbis Geronticus eremita, a Critically Endangered species. Here, a conservation project has been underway to protect the birds at their breeding site and in surrounding areas. As Souss-Massa is a formally protect area, the government (HCEFLCD) is closely involved in managing the guards. At Sidi Bou Ghaba, there is a natural reserve where local guards have been under the employ of a non-governmental organisation. A local guardian system is thus a mechanism that can work in Morocco, and thus should be perfectly feasible for the Great Bustard areas. However, such a system would no doubt benefit from a recognised protection status of the key sites, whilst decisions would be needed as to whether the government or civil society would manage/coordinate a network of local guardians.

\subsubsection{Strategy 2 - Minimise power line collisions and impacts from other infrastructure}

\section{a. Minimise power line collisions}

Whilst it is hard to quantify the impact of power line collisions on Great Bustards in Morocco due to a lack of collision monitoring, this threat is known to be the main non-natural mortality cause in this species (Alonso et al. 2003, Martín et al. 2004). The Moroccan population is so critically low that even the loss of one adult bustard per year to collision could

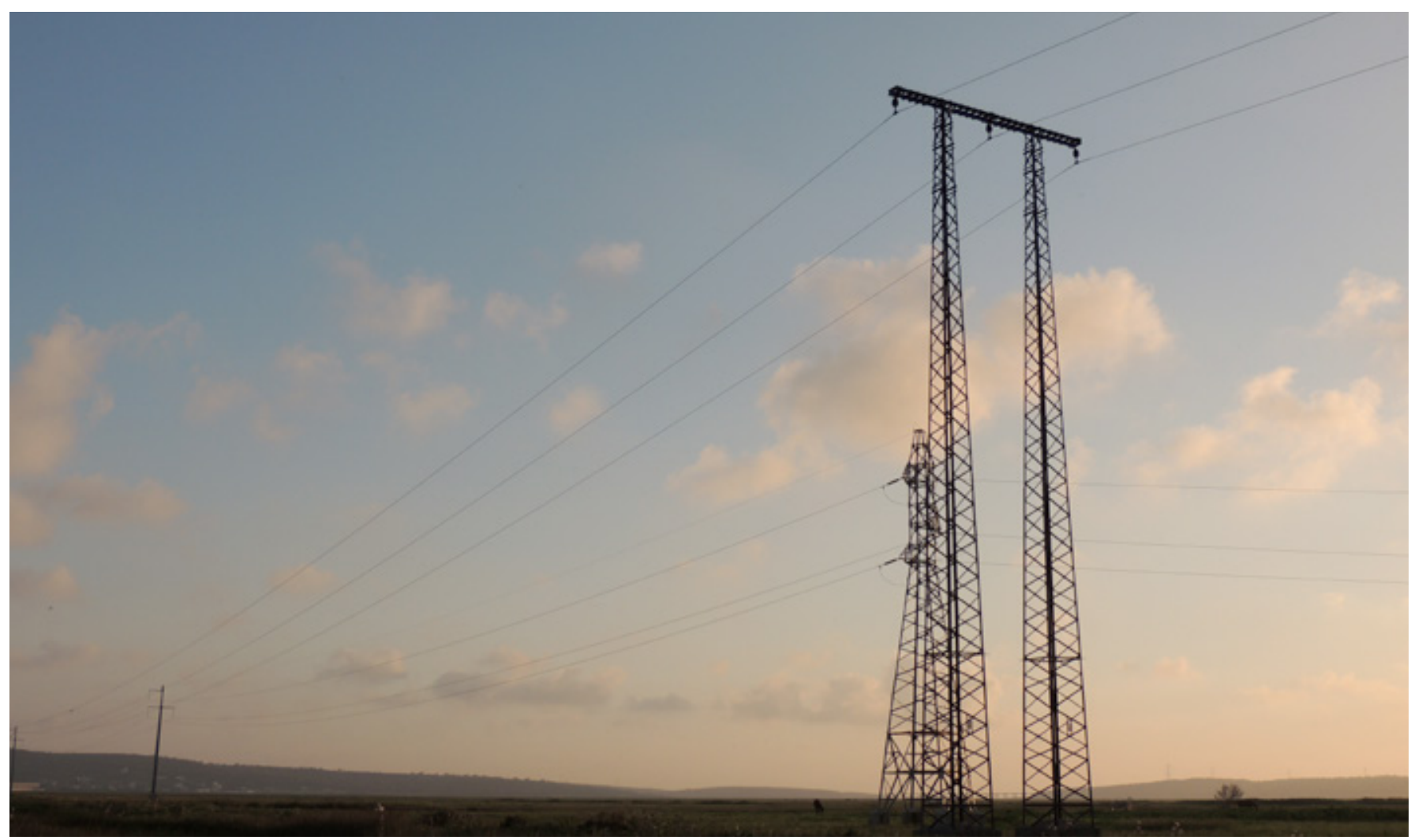

Power line across a floodplain where Great Bustards used to be found in Kanouat (photo (C) Tim Dodman). 


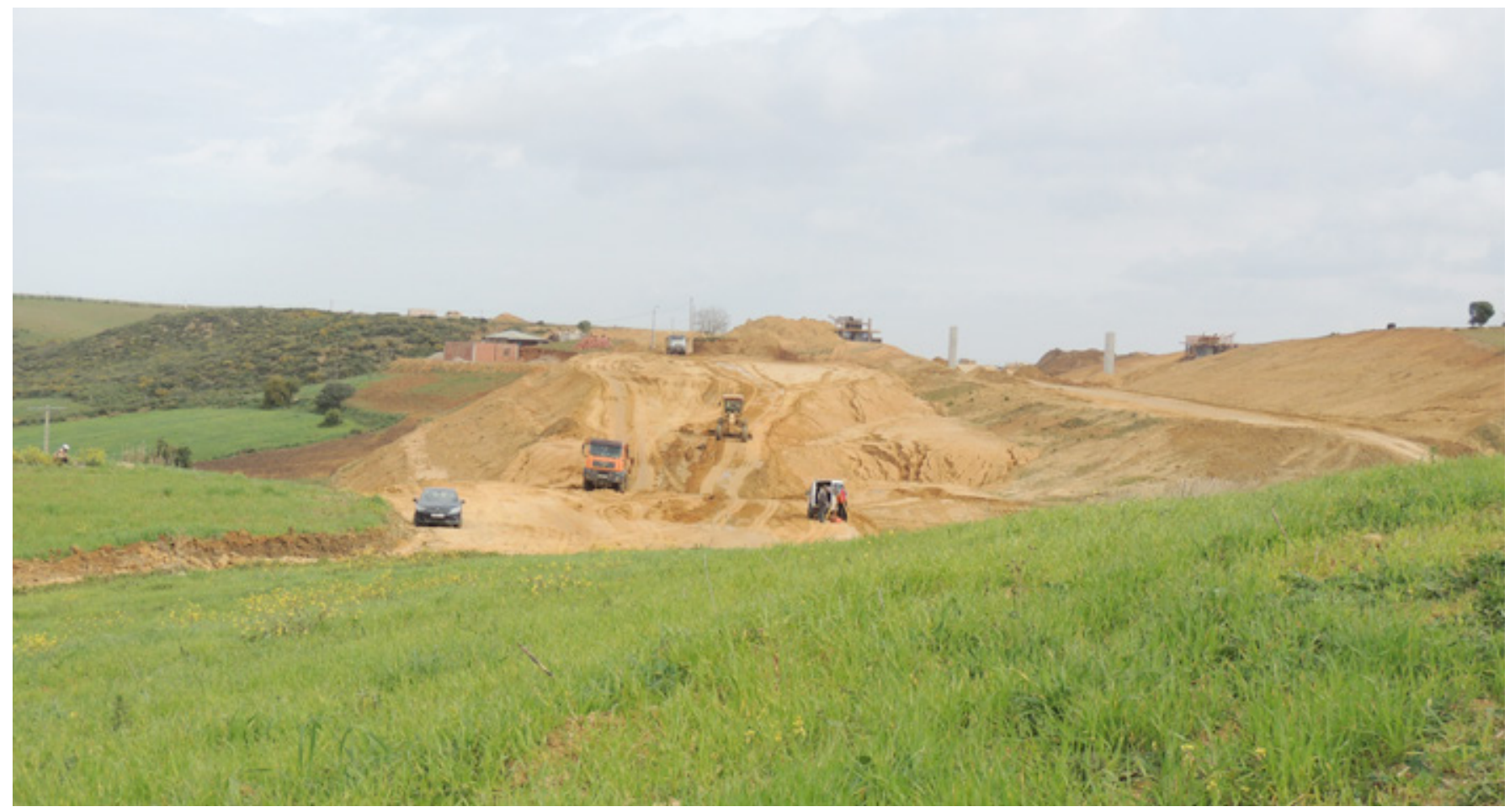

Construction of the high-speed railway line through Tendafel (photo (C) Tim Dodman).

negatively impact the population. Meanwhile, expansion of the national power line network in Morocco has been intensive, including across the remaining Great Bustard areas, so the potential for collisions is very high, given the presence of power lines in sensitive areas, where bustards have been seen in flight. Most respondents considered that it would be well worthwhile marking the most sensitive power lines with anti-collision devices to make them more visible to Great Bustards. Such devices, when placed appropriately, can contribute to reduced bird mortality (e.g. Alonso et al. 1994, Barrientos et al. 2011 and 2012). However, the most critical sectors of power lines crossing the central areas of leks should either be buried or removed and rerouted. Although expensive, underground cabling is the only way to reliably prevent collisions when wires must cross through core areas. Funding for all power line collision mitigation actions should be sourced urgently, e.g. via the electrical companies, government and private or international funding sources. Burying, rerouting and marking lines should be planned in close consultation with Office National de l'Électricité (ONE, National Electricity Office).

In addition, it should be possible to prevent new potentially harmful infrastructural developments in Great Bustard areas, such as new power lines and potentially wind turbines or other developments. Professional independent Environmental Impact Assessments should be conducted during feasibility studies for all developments.

\section{b. Minimise impacts from other infrastructure}

The high-speed train, the Ligne de Train à Grande Vitesse (LGV) or Train à Grande Vitesse (TGV) that is currently being constructed from Tangier southwards to Kénitra (eventually planned to reach Casablanca) passes directly through the probably former Great Bustard area of Tendafel and parts of Araoua. Other infrastructural developments underway include roads and water pipes, whilst wind turbines are a common feature on hills further north, which impact migratory soaring birds. Bird strikes with high-speed rail lines can represent an important factor of human-induced mortality for Great Bustards; 18 Great Bustards were killed in a $22 \mathrm{~km}$ length of a high-speed rail line that crosses a bustard distribution area in central Spain (Life Impacto Cero 2014). Whilst the TGV may pose a direct threat to Great Bustards, it inevitably also contributes to carving up habitat, i.e. fragmentation, whilst disturbance may be a further impacting factor. There is an agreement between the government and LGV for three years, which should allow for financing a study and potentially other activities on the Great Bustard. However, the Office National des Chemins de Fer (ONCF, National Railways Office) has not furthered the agreement yet. This needs to be resolved urgently as a key potential source of funds.

\subsubsection{Strategy 3 - Secure bustard habitat in key areas}

It seems that the only existing viable leks in 2015 are at Araoua and possibly at Tleta-Rissana. However, neither area benefits from designation for site conservation. It is essential to investigate this issue and identify the most appropriate realistic designations for these two areas and potentially for other areas where bustards were found until recently, especially given the goal of expanding the Great Bustard's range. 
It is not possible to define within this plan the exact measure of designation required, as this requires a proper consultative process, with local stakeholder workshops (within the areas) and negotiations between government, local communities and civil society. However, it seems feasible to review and potentially change existing SIBE boundaries and to look into alternative, stronger, measures of site protection through legislation introduced in 2010.

The Plan Maroc Vert (Green Morocco Plan)² should also be better implemented to encourage a mosaic and diversity of habitats and to promote organic agriculture. It will be vital for the Great Bustard's survival to maintain the habitat at Araoua and prevent any significant agricultural development. Tleta-Rissana appears to be more modified, with large parts in danger of becoming dominated by monoculture. It is likely necessary for this area to set some fields aside and return them to a more traditional management style.

\subsubsection{Strategy 4 Strengthen awareness and valuation}

Some awareness activities have been undertaken in the past. However, it was widely felt that awareness activities alone were not useful, and needed to be backed up by surveillance and conservation action. For instance, some large posters remain on the main highway (autoroute) featuring bustards, but it is questionable if they serve a useful purpose unless conservation actions are underway. Some respondents thought such advertising might have even attracted hunters to the area, keen to shoot a Great Bustard.

Nevertheless, a targeted awareness campaign is an essential component of a Great Bustard conservation programme, especially to engage local people, local hunting groups and decision makers.

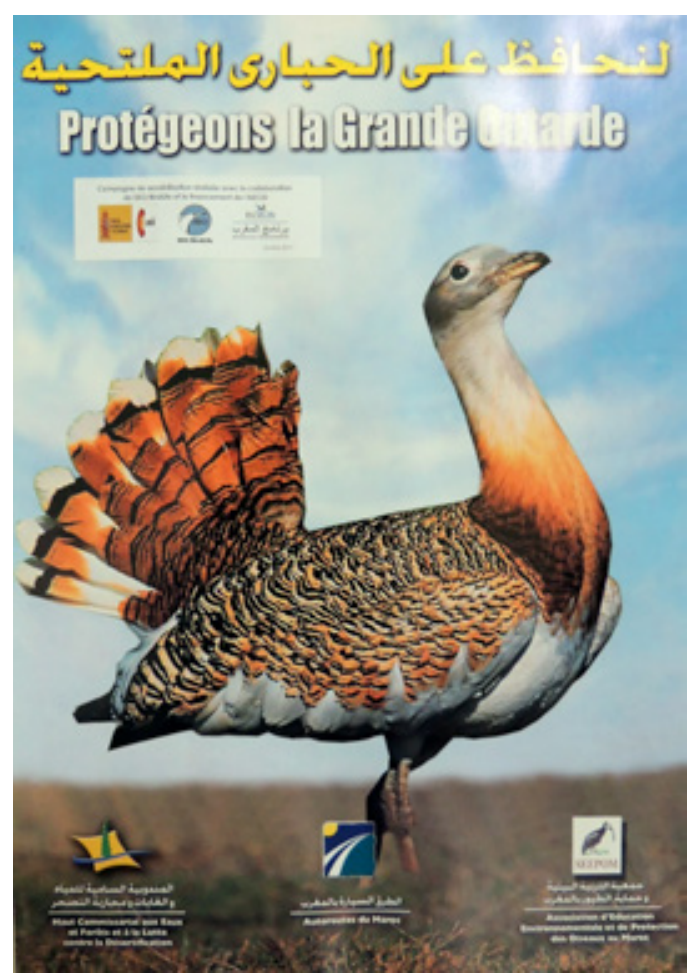

A poster encouraging protection of the Great Bustard in Morocco. These and other awareness materials were developed and distributed locally between 2000 and 2003 within the framework of the project "Viabilidad de la población de Avutardas de Marruecos. Bases científicas para su conservación (2000-2003)" funded by the Agencia Española de Cooperación Internacional para el Desarrollo (AECID), Ministry of Foreign Affairs of Spain (Alonso 2004).
Another important factor linked to awareness is to build valuation of the Great Bustard, both its cultural value and economic value. There are various options that could be developed to contribute to this, including:

\section{- Great Bustard ecotourism}

- There is interest in developing Great Bustard ecotourism, especially including the bustard area in a birding circuit of (northern) Morocco.

- Some stakeholders recommend construction of hides or observation areas, though any such structure would need to be a good distance from any lek to ensure there was no disturbance.

- The Great Bustard is not an easy bird to see, so tourism may only appeal to the more 'dedicated' birdwatchers.

\section{- Great Bustard mark}

- One option for bringing in resources would be to develop a Great Bustard mark, especially for quality traditional agricultural products, such as local cheese, wheat and broad beans.

- Branding can add value to goods and generate markets. 


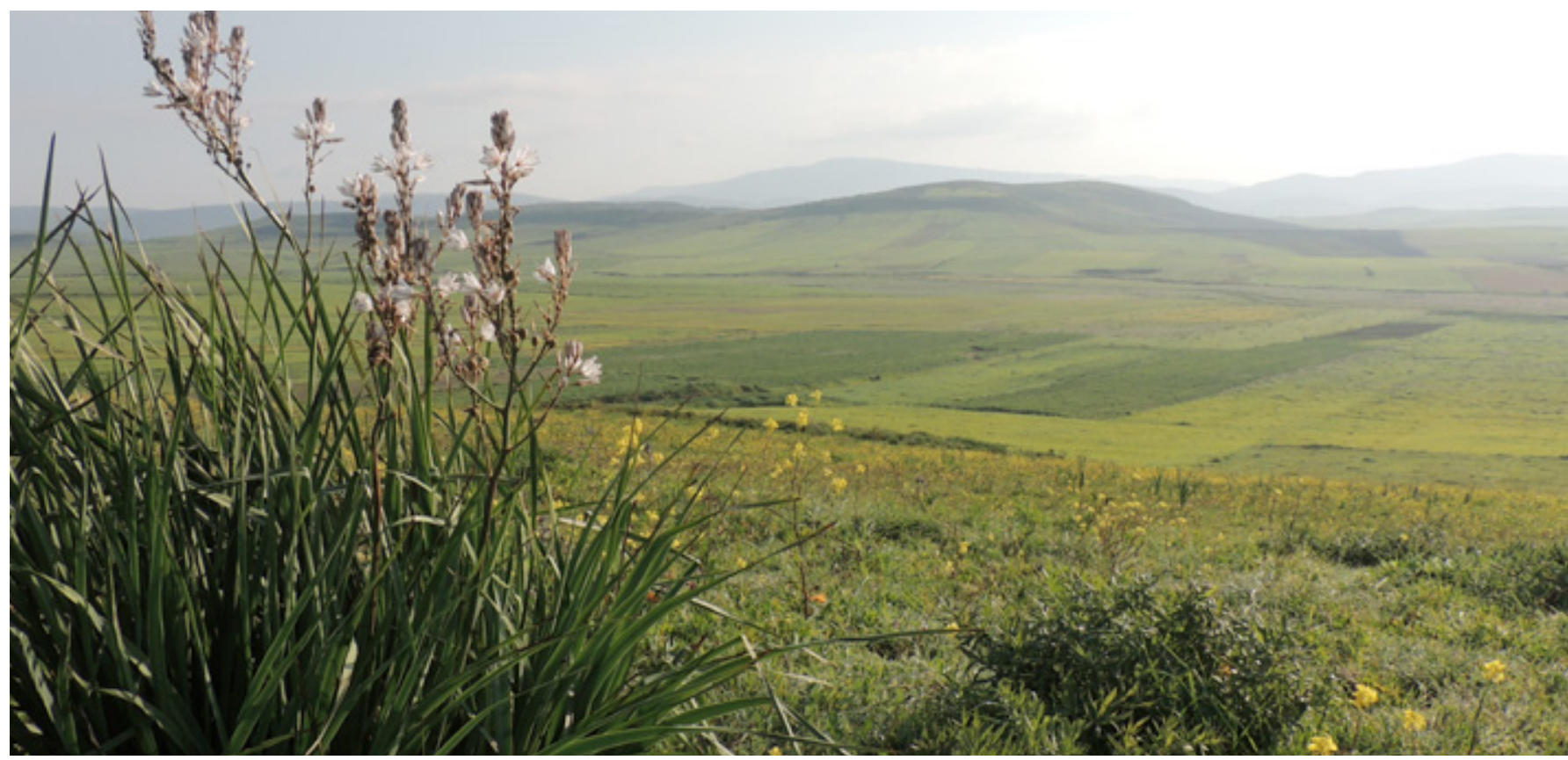

Rolling hills and valleys and a mosaic of habitats in an agricultural landscape make up the area of Araoua, the only remaining stronghold for Great Bustard in Morocco (photo (C) Tim Dodman).

\subsubsection{Strategy 5 Research and monitoring}

A number of questions remain unanswered concerning the conservation management needs of the Great Bustard in Morocco. Of priority is to carry out accurate annual censuses of the population during the courtship / lekking season, when birds gather for ritual courtship displays and mating. Such surveys have been carried out in the past, so direct comparisons may be made to determine the population trend. Collision / casualty monitoring should also be conducted regularly to monitor the impact of power lines and other infrastructure. All monitoring results need to be readily available and analysed in order to inform and, where necessary, revise conservation management actions.

However, little is known about the movements and utilisation of habitat outside this season. It may be expected, for instance, that bustards move out of some agricultural areas, especially when crops are cut and cover diminished. There is potential to investigate movements and habitat use through a range of methods, and to obtain a much better idea of distribution and habitat use throughout the year.

Overall, an integrated research programme should be developed, ideally with the support and involvement of partners in Spain, notably the Museo Nacional de Ciencias Naturales, Consejo Superior de Investigaciones Científicas (CSIC) of Madrid (team currently led by Prof. J.C. Alonso). A capacity building element should be included, in order to build experience and confidence of a Moroccan team, who can carry out research and monitoring throughout the year, following on from past monitoring and the project "Viabilidad de la población de Avutardas de Marruecos. Bases científicas para su conservación (2000-2003)." The research programme should consider the option of implementing a population reinforcement plan through the release of young bustards, e.g. by collecting eggs in Spain and incubation and release in Morocco; this is not included within the current strategy, but may be a required future action.

\subsubsection{Strategy 6 Sustainable funding}

Short-term funding requirements may be met partially through the agreement between HCEFLCD and the LGV, whilst the IUCN Centre for Mediterranean Cooperation may be in a position to support searching funds for a pilot project to implement a part of the action plan. However, sustainable funding needs to be identified for the mid-term and long-term. 


\subsection{Strategic Objectives}

During the stakeholder workshop, six objectives were set and translated into Long-term and Strategic Objectives (Table 3).

Table 3. Long-term and Strategic Objectives (LTO) for conservation of Great Bustards in northwest Morocco

\begin{tabular}{|c|c|}
\hline $\begin{array}{l}\text { Intervention } \\
\text { Strategy }\end{array}$ & Long-term and Strategic Objectives (LTO) \\
\hline $\begin{array}{l}\text { S1 - Establish } \\
\text { surveillance } \\
\text { capacity }\end{array}$ & $\begin{array}{l}\text { LTO: By 2025, effective surveillance and in-situ monitoring have enabled the Great Bustard population in Morocco to } \\
\text { increase by } 25 \% \text {. } \\
\text { 1. By 2017, local écogardes are recruited backed up by an effective coordination unit. } \\
\text { 2. By 2018, all leks are safeguarded from illegal hunters and legislation implemented. } \\
\text { 3. By 2018, all communities and hunters active in northwest Morocco are fully aware of the protected status of Great Bustard. } \\
\text { 4. By 2020, sustainable mechanisms are in place to minimise collisions and control illegal wildlife hunting in Araoua and Tleta- } \\
\text { Rissana, and to prevent Great Bustard poaching in all areas. }\end{array}$ \\
\hline $\begin{array}{l}\text { S2 - Minimise } \\
\text { power line } \\
\text { collisions } \\
\text { and impacts } \\
\text { from other } \\
\text { infrastructure }\end{array}$ & $\begin{array}{l}\text { LTO: By 2025, the risk of Great Bustard collision with power lines is minimised and the impacts of transport and other } \\
\text { infrastructure diminished. } \\
\text { 1. By 2017, agreements are in place to remove or mark existing power lines in Araoua and Tleta-Rissana and that no new power } \\
\text { lines will traverse leks. } \\
\text { 2. By 2018, the main 'problem power lines' in Araoua and Tleta-Rissana have been removed, with markers placed on all other lines } \\
\text { within bustard habitat in these areas. } \\
\text { 3. By 2019, agreements are in place to minimise potential risk of collisions in Tendafel, Kanouat and Chekbouchan. } \\
\text { 4. By 2020, collisions of Great Bustards with power lines are no longer a threat in key areas. } \\
\text { 5. By 2020, the negative impacts of road, rail and other infrastructure are diminished. }\end{array}$ \\
\hline $\begin{array}{l}\text { cure } \\
\text { in key } \\
\text { l areas }\end{array}$ & $\begin{array}{l}\text { LTO: By 2025, Great Bustards are breeding successfully in Araoua and Teta-Rissana and have returned to at least two } \\
\text { additional lek areas. } \\
\text { 1. By 2017, clear new designations have been established and formalised for Araoua and Tleta-Rissana based on their status as } \\
\text { essential areas for Great Bustard survival in Morocco. } \\
\text { 2. By } 2018, \text { mechanisms and incentives are in place to promote the 'Plan Maroc Vert' in all current and former Great Bustard lek } \\
\text { areas. } \\
\text { 3. By 2018, agreements are being implemented to secure a mosaic of habitats that benefit Great Bustards in Araoua and Tleta- } \\
\text { Rissana. } \\
\text { 4. By 2020, agreements have been reached to reinstate Tendafel, Kanouat and Chekbouchan as potential lek areas with } \\
\text { appropriate undisturbed habitat available. }\end{array}$ \\
\hline $\begin{array}{l}\text { S4 - Strengthen } \\
\text { awareness and } \\
\text { valuation }\end{array}$ & $\begin{array}{l}\text { LTO: By 2025, rural communities in northwest Morocco are benefiting from an increasing population of Great Bustards } \\
\text { through sustainable economic enterprises. } \\
\\
\text { 1. By 2017, inhabitants in Araoua and Tleta-Rissana are aware about the vital role of their land to save the Great Bustard in } \\
\text { Morocco, about new conservation measures underway and the need to minimise disturbance. } \\
\text { 2. By 2019, awareness of Great Bustard conservation measures is entrenched within public institutions, especially schools. } \\
\text { 3. By 2020, a community-based economic incentives programme is underway, likely to include branding of 'Great Bustard' } \\
\text { products. } \\
\text { 4. By 2020, low-level ecotourism initiatives are under operation that feature Great Bustards in their itinerary. }\end{array}$ \\
\hline $\begin{array}{l}\text { S5-Research } \\
\text { and monitoring }\end{array}$ & $\begin{array}{l}\text { LTO: By 2025, effective research and monitoring of population trends, behaviour, movements, habitat requirements and } \\
\text { other parameters have yielded consenvation solutions, enabling the Great Bustard population to increase. } \\
\text { 1. 2016-2025: Censuses of Great Bustards (and sex ratios) in Araoua and Tleta-Rissana are conducted annually during early } \\
\text { spring, and every three years across all leks to determine population trends. } \\
\text { 2. 2016-2025: A casualty transect monitoring programme is established and implemented to monitor bird casualties caused by } \\
\text { power lines in all lek areas. } \\
\text { 3. By 2017, a programme of integrated research is established to investigate the conservation status of Great Bustards throughout } \\
\text { the year, including behaviour, movements and habitat requirements. } \\
\text { 4. By 2018, all identified actual and potential threats are being monitored. } \\
\text { 5. By 2018, there is good local capacity to conduct censuses and research. }\end{array}$ \\
\hline $\begin{array}{l}\text { S6 - Sustainable } \\
\text { funding }\end{array}$ & $\begin{array}{l}\text { LTO: By 2025, Great Bustard conservation in Morocco is assured through secured sustainable financing mechanisms. } \\
\text { 1. In 2016, the agreement between HCEFLCD and the LGV is functional and funds are available for immediate mitigating actions. } \\
\text { 2. By 2017, additional external funds and partnerships are in place, especially to address priority issues of poaching and collisions. } \\
\text { 3. By 2018, government commitments are secured for long-term financing of local surveillance. } \\
\text { 4. By 2020, Great Bustard conservation is fully integrated into annual government budgets. }\end{array}$ \\
\hline
\end{tabular}




\section{Conservation Action Plan}

Table 4. Prioritised actions with timescales, responsibilities and approximate costs for implementing the Action Plan

\begin{tabular}{|c|c|c|c|c|c|c|}
\hline $\begin{array}{l}\text { Strategic } \\
\text { Objective }\end{array}$ & Action & Priority & Timescale & $\begin{array}{l}\text { Organisations } \\
\text { / persons } \\
\text { responsible }\end{array}$ & $\begin{array}{l}\text { Cost (Low, } \\
\text { Medium, } \\
\text { High) }\end{array}$ & Notes \\
\hline \multicolumn{7}{|c|}{ S1 - Establish surveillance capacity } \\
\hline \multicolumn{7}{|c|}{$\begin{array}{l}\text { LTO By 2025, effective surveillance and in-situ monitoring have enabled the Great Bustard population in Morocco to increase by } \\
25 \% .\end{array}$} \\
\hline \multirow{4}{*}{$\begin{array}{l}\text { 1. By } 2017, \text { local } \\
\text { écogardes are } \\
\text { recruited backed } \\
\text { up by an effective } \\
\text { coordination unit. }\end{array}$} & $\begin{array}{l}1.1 \text { Identify and recruit } \\
\text { project coordinator and } \\
\text { assistant }\end{array}$ & $\star \star \star$ & By end 2016 & $\begin{array}{l}\text { HCEFLCD, in } \\
\text { coordination } \\
\text { with GREPOM }\end{array}$ & High & $\begin{array}{l}\text { Meetings to determine if staff } \\
\text { of HCEFLCD or GREPOM }\end{array}$ \\
\hline & $\begin{array}{l}1.2 \text { Recruit 2-10 écogardes } \\
\text { to guard leks and breeding } \\
\text { areas and monitor } \\
\text { collisions }\end{array}$ & $\star \star \star$ & $\begin{array}{l}\text { By February } \\
2017\end{array}$ & $\begin{array}{l}\text { HCEFLCD, in } \\
\text { coordination } \\
\text { with GREPOM }\end{array}$ & High & $\begin{array}{l}\text { Écogardes drawn from local } \\
\text { communities of Araoua and } \\
\text { Tleta-Rissana }\end{array}$ \\
\hline & $\begin{array}{l}1.3 \text { Mobilise resources } \\
\text { for effective surveillance } \\
\text { (especially to control } \\
\text { poaching and disturbance), } \\
\text { censuses and collision } \\
\text { monitoring }\end{array}$ & 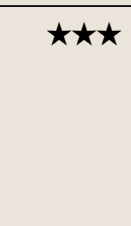 & By end 2017 & $\begin{array}{l}\text { HCEFLCD, in } \\
\text { coordination } \\
\text { with GREPOM; } \\
\text { seek external } \\
\text { support }\end{array}$ & High & $\begin{array}{l}\text { Transport (4WD / motorbike, } \\
\text { bicycles), phones, telescope } \\
\text { / binoculars / uniforms and } \\
\text { boots }\end{array}$ \\
\hline & $\begin{array}{l}1.4 \text { Establish a physical } \\
\text { centre / presence in Araoua }\end{array}$ & $\star \star$ & By 2018 & $\begin{array}{l}\text { HCEFLCD, in } \\
\text { coordination } \\
\text { with GREPOM; } \\
\text { seek external } \\
\text { support }\end{array}$ & Medium & $\begin{array}{l}\text { The project needs a local } \\
\text { centre / office; key staff may } \\
\text { also need accommodation } \\
\text { provided }\end{array}$ \\
\hline \multirow[t]{3}{*}{$\begin{array}{l}\text { 2. By 2018, all leks } \\
\text { are safeguarded } \\
\text { from illegal hunters } \\
\text { and legislation } \\
\text { implemented. }\end{array}$} & $\begin{array}{l}2.1 \text { Maintain a permanent } \\
\text { surveillance of lek areas } \\
\text { from February to April each } \\
\text { year }\end{array}$ & $\star \star \star \star$ & $\begin{array}{l}\text { By March } \\
\text { 2018, then } \\
\text { every spring }\end{array}$ & $\begin{array}{l}\text { Project } \\
\text { Coordinator }\end{array}$ & Low & $\begin{array}{l}\text { Écogarde rotas, effective } \\
\text { coordination }\end{array}$ \\
\hline & $\begin{array}{l}2.2 \text { A good informer } \\
\text { network is established } \\
\text { to report on bustard } \\
\text { observations and locations, } \\
\text { collision incidents and any } \\
\text { suspicious actions. }\end{array}$ & $\star \star \star$ & $\begin{array}{l}\text { By March } \\
\text { 2018, then } \\
\text { ongoing } \\
\text { growth }\end{array}$ & $\begin{array}{l}\text { Project } \\
\text { Coordinator and } \\
\text { écogardes }\end{array}$ & Low & $\begin{array}{l}\text { Local écogarde system } \\
\text { encourages local informers }\end{array}$ \\
\hline & $\begin{array}{l}2.3 \text { Legislation / judicial } \\
\text { system is reviewed to } \\
\text { establish tough sentences }\end{array}$ & $\star \star$ & By end 2018 & $\begin{array}{l}\text { HCEFLCD / } \\
\text { GREPOM with } \\
\text { legislature, } \\
\text { courts and local } \\
\text { politicians }\end{array}$ & Low & $\begin{array}{l}\text { Awareness of tough } \\
\text { sentences should deter } \\
\text { poachers }\end{array}$ \\
\hline \multirow{3}{*}{$\begin{array}{l}\text { 3. By } 2018 \text {, all } \\
\text { communities and } \\
\text { hunters active in } \\
\text { northwest Morocco } \\
\text { are fully aware of } \\
\text { the protected status } \\
\text { of Great Bustard. }\end{array}$} & $\begin{array}{l}3.1 \text { Establish local boards } \\
\text { to guide the project, with } \\
\text { places for community } \\
\text { leaders and local hunting } \\
\text { groups }\end{array}$ & $\star \star$ & $\begin{array}{l}\text { Start in } \\
2016 / 17 \text {, } \\
\text { then } \\
\text { ongoing }\end{array}$ & $\begin{array}{l}\text { HCEFLCD / } \\
\text { GREPOM, } \\
\text { Project } \\
\text { Coordinator }\end{array}$ & Low & $\begin{array}{l}\text { Community and hunter } \\
\text { presence on local bustard } \\
\text { management boards (Araoua } \\
\text { and Tleta-Rissana) improves } \\
\text { relations }\end{array}$ \\
\hline & $\begin{array}{l}\text { 3.2 Local hunting groups } \\
\text { actively deter illegal hunting } \\
\text { during their amodiation in } \\
\text { all (former) lek areas }\end{array}$ & $\star \star$ & $\begin{array}{l}\text { By } 2017, \\
\text { then } \\
\text { ongoing }\end{array}$ & $\begin{array}{l}\text { Project } \\
\text { Coordinator, in } \\
\text { cooperation with } \\
\text { local hunting } \\
\text { groups } \\
\end{array}$ & Low & $\begin{array}{l}\text { Local hunting groups usually } \\
\text { employ their own guards } \\
\text { to control their hunting } \\
\text { amodiation (lease agreement) }\end{array}$ \\
\hline & $\begin{array}{l}\text { 3.3 Extend awareness } \\
\text { programmes of S4 1.1- } \\
1.3 \text { to include local and } \\
\text { other hunters, including } \\
\text { information on penalties for } \\
\text { hunting }\end{array}$ & $\star \star$ & $\begin{array}{l}\text { By } 2018, \\
\text { then } \\
\text { ongoing }\end{array}$ & $\begin{array}{l}\text { Project } \\
\text { Coordinator, in } \\
\text { cooperation with } \\
\text { HCEFLD and } \\
\text { local hunting } \\
\text { groups }\end{array}$ & Low & $\begin{array}{l}\text { Hunters especially need to } \\
\text { be well aware about the } \\
\text { protected status of the Great } \\
\text { Bustard and penalties for } \\
\text { hunting. Écogarde presence } \\
\text { should deter hunting }\end{array}$ \\
\hline
\end{tabular}




\begin{tabular}{|c|c|c|c|c|c|c|}
\hline $\begin{array}{l}\text { Strategic } \\
\text { Objective }\end{array}$ & Action & Priority & Timescale & $\begin{array}{l}\text { Organisations } \\
\text { / persons } \\
\text { responsible }\end{array}$ & \begin{tabular}{|l} 
Cost (Low, \\
Medium, \\
High)
\end{tabular} & Notes \\
\hline \multirow{3}{*}{$\begin{array}{l}\text { 4. By 2020, } \\
\text { sustainable } \\
\text { mechanisms } \\
\text { are in place to } \\
\text { minimise collisions } \\
\text { and control illegal } \\
\text { wildlife hunting } \\
\text { in Araoua and } \\
\text { Tleta-Rissana, and } \\
\text { to prevent Great } \\
\text { Bustard poaching in } \\
\text { all areas. }\end{array}$} & $\begin{array}{l}\text { 4.1 Surveillance } \\
\text { programme is adopted fully } \\
\text { by government for long- } \\
\text { term implementation } \\
\end{array}$ & $\star \star$ & $\begin{array}{l}\text { By March } \\
2020\end{array}$ & $\begin{array}{l}\text { HCEFLCD, in } \\
\text { coordination } \\
\text { with GREPOM }\end{array}$ & Low & $\begin{array}{l}\text { Government integrates } \\
\text { surveillance into regular } \\
\text { annual programme }\end{array}$ \\
\hline & $\begin{array}{l}\text { 4.2 Train all project staff } \\
\text { and community members }\end{array}$ & $\star \star \star$ & $\begin{array}{l}\text { Start in } \\
\text { 2017, then } \\
\text { ongoing }\end{array}$ & $\begin{array}{l}\text { HCEFLCD, in } \\
\text { coordination } \\
\text { with GREPOM }\end{array}$ & Medium & $\begin{array}{l}\text { Essential to train écogardes } \\
\text { in surveillance / monitoring }\end{array}$ \\
\hline & $\begin{array}{l}\text { 4.3 Extend surveillance } \\
\text { system to Tendafel, } \\
\text { Kanouat and Chekbouchan }\end{array}$ & $\star \star$ & By 2020 & $\begin{array}{l}\text { HCEFLCD, in } \\
\text { coordination } \\
\text { with GREPOM }\end{array}$ & High & $\begin{array}{l}\text { Surveillance of all hunting } \\
\text { activities. Recruitment of } \\
\text { extra local écogardes for new } \\
\text { areas }\end{array}$ \\
\hline \multicolumn{7}{|c|}{ S2 - Minimise power line collisions and impacts from other infrastructure } \\
\hline \multicolumn{7}{|c|}{$\begin{array}{l}\text { LTO By 2025, the risk of Great Bustard collision with power lines is minimised and the impacts of transport and other } \\
\text { infrastructure diminished }\end{array}$} \\
\hline \multirow{3}{*}{$\begin{array}{l}\text { 1. By 2017, } \\
\text { agreements are in } \\
\text { place to remove } \\
\text { or mark existing } \\
\text { power lines in } \\
\text { Araoua and Tleta- } \\
\text { Rissana and that } \\
\text { no new power lines } \\
\text { will traverse leks. }\end{array}$} & $\begin{array}{l}1.1 \text { Review the power line } \\
\text { infrastructure, confirm } \\
\text { 'no power line zones' } \\
\text { and develop a collision } \\
\text { mitigation plan for all } \\
\text { bustard areas } \\
\end{array}$ & $\star \star \star \star$ & By end 2016 & $\begin{array}{l}\text { HCEFLCD and } \\
\text { ONE with Project } \\
\text { Coordinator and } \\
\text { stakeholder } \\
\text { participation; } \\
\text { CSIC }\end{array}$ & Medium & $\begin{array}{l}\text { Invite expertise from Europe } \\
\text { (where collision mitigation } \\
\text { has been achieved in some } \\
\text { areas). CSIC has already } \\
\text { carried out useful analysis } \\
\text { (Palacín et al. 2016) } \\
\end{array}$ \\
\hline & $\begin{array}{l}\text { 1.2 Develop and sign } \\
\text { agreement with ONE to } \\
\text { remove 'problem power } \\
\text { lines' } \\
\end{array}$ & $\star \star \star \star$ & $\begin{array}{l}\text { By June } \\
2017\end{array}$ & $\begin{array}{l}\text { HCEFLCD and } \\
\text { ONE }\end{array}$ & Low & $\begin{array}{l}\text { Convention should be } \\
\text { a legally binding inter- } \\
\text { ministerial document }\end{array}$ \\
\hline & $\begin{array}{l}\text { 1.3 Develop and sign } \\
\text { convention with ONE to } \\
\text { prevent new power lines } \\
\text { cutting across bustard } \\
\text { habitat }\end{array}$ & $\star \star \star \star$ & $\begin{array}{l}\text { By June } \\
2017\end{array}$ & $\begin{array}{l}\text { HCEFLCD and } \\
\text { ONE }\end{array}$ & Low & $\begin{array}{l}\text { Agreement should be } \\
\text { a legally binding inter- } \\
\text { ministerial document }\end{array}$ \\
\hline \multirow{4}{*}{$\begin{array}{l}\text { 2. By 2018, the } \\
\text { main 'problem } \\
\text { power lines' in } \\
\text { Araoua and Tleta- } \\
\text { Rissana have been } \\
\text { removed, with } \\
\text { markers placed on } \\
\text { all other lines within } \\
\text { bustard habitat in } \\
\text { these areas. }\end{array}$} & $\begin{array}{l}2.1 \text { Analyse all power lines } \\
\text { and identify and prioritise } \\
\text { those that require removal } \\
\text { (rerouting or underground } \\
\text { cabling) or anti-collision } \\
\text { devices/markers }\end{array}$ & $\star \star \star \star$ & By end 2016 & $\begin{array}{l}\text { Project } \\
\text { Coordinator; } \\
\text { CSIC }\end{array}$ & Low & $\begin{array}{l}\text { Invite experts from Europe } \\
\text { to assist with field work and } \\
\text { analysis. Removal of power } \\
\text { lines includes replacement by } \\
\text { alternative routes and burying } \\
\text { cables underground }\end{array}$ \\
\hline & $\begin{array}{l}\text { 2.2 Work with experienced } \\
\text { partners to identify suitable } \\
\text { methods for removing } \\
\text { power lines (underground } \\
\text { cabling or rerouting) and } \\
\text { marking wires, and develop } \\
\text { a timetable and budget } \\
\end{array}$ & $\star \star \star \star$ & $\begin{array}{l}\text { By March } \\
2017\end{array}$ & $\begin{array}{l}\text { Project } \\
\text { Coordinator with } \\
\text { external support }\end{array}$ & Medium & $\begin{array}{l}\text { Work with partners in } \\
\text { Europe on a technical level; } \\
\text { determine actions required to } \\
\text { effectively mitigate collisions; } \\
\text { develop funding proposal to } \\
\text { implement actions }\end{array}$ \\
\hline & $\begin{array}{l}2.3 \text { Remove 'problem } \\
\text { power lines' through } \\
\text { rerouting or underground } \\
\text { cabling }\end{array}$ & $\star \star \star \star$ & $\begin{array}{l}\text { Commence } \\
\text { urgently; } \\
\text { complete } \\
\text { priority lines } \\
\text { by June } \\
\text { 2018, others } \\
\text { by end } 2018 \\
\end{array}$ & $\begin{array}{l}\text { HCEFLCD and } \\
\text { ONE; external } \\
\text { partners }\end{array}$ & High & $\begin{array}{l}\text { Raise funds and identify } \\
\text { international partners to } \\
\text { support this urgent activity }\end{array}$ \\
\hline & $\begin{array}{l}2.4 \text { Equip power lines not } \\
\text { being removed with anti- } \\
\text { collision devices/markers }\end{array}$ & $\star \star \star$ & $\begin{array}{l}\text { Commence } \\
\text { urgently; } \\
\text { complete } \\
\text { priority lines } \\
\text { by June } \\
2018 \text {, others } \\
\text { by end } 2018 \\
\end{array}$ & $\begin{array}{l}\text { HCEFLCD and } \\
\text { ONE }\end{array}$ & High & $\begin{array}{l}\text { This activity could be } \\
\text { completed earlier if analyses } \\
\text { concluded and partners } \\
\text { found }\end{array}$ \\
\hline
\end{tabular}




\begin{tabular}{|c|c|c|c|c|c|c|}
\hline $\begin{array}{l}\text { Strategic } \\
\text { Objective }\end{array}$ & Action & Priority & Timescale & $\begin{array}{l}\text { Organisations } \\
\text { / persons } \\
\text { responsible }\end{array}$ & $\begin{array}{l}\text { Cost (Low, } \\
\text { Medium, } \\
\text { High) }\end{array}$ & Notes \\
\hline \multirow{2}{*}{$\begin{array}{l}\text { 3. By 2019, } \\
\text { agreements are in } \\
\text { place to minimise } \\
\text { potential risk } \\
\text { of collisions in } \\
\text { Tendafel, Kanouat } \\
\text { and Chekbouchan. }\end{array}$} & $\begin{array}{l}3.1 \text { Review the power line } \\
\text { networks, assess their } \\
\text { potential impacts and } \\
\text { develop mitigation options }\end{array}$ & $\star \star \star$ & $\begin{array}{l}\text { By June } \\
2017\end{array}$ & $\begin{array}{l}\text { HCEFLCD and } \\
\text { ONE; external } \\
\text { advice from } \\
\text { Bustard SG and } \\
\text { CSIC }\end{array}$ & Medium & $\begin{array}{l}\text { This will involve field work } \\
\text { to identify problem lines and } \\
\text { prioritise those for marking, } \\
\text { plus meetings with ONE }\end{array}$ \\
\hline & $\begin{array}{l}\text { 3.2 Agree mitigating } \\
\text { options with ONE, } \\
\text { then develop and sign } \\
\text { convention to implement } \\
\text { mitigation measures }\end{array}$ & $\star \star \star$ & $2018-2019$ & $\begin{array}{l}\text { HCEFLCD and } \\
\text { ONE }\end{array}$ & $\begin{array}{l}\text { Low; High for } \\
\text { implementing }\end{array}$ & $\begin{array}{l}\text { The convention should follow } \\
\text { / adopt the collision mitigation } \\
\text { plan and will need an agreed } \\
\text { budget and identified support }\end{array}$ \\
\hline \multirow{2}{*}{$\begin{array}{l}\text { 4. By 2020, } \\
\text { collisions of Great } \\
\text { Bustards with } \\
\text { power lines are no } \\
\text { longer a threat in } \\
\text { key areas. }\end{array}$} & \begin{tabular}{|l|}
4.1 Écogardes regularly \\
monitor power lines and \\
check for any bird collisions \\
\end{tabular} & $\star \star \star$ & $\begin{array}{l}\text { By 2017, } \\
\text { then } \\
\text { ongoing }\end{array}$ & $\begin{array}{l}\text { HCEFLCD / } \\
\text { GREPOM }\end{array}$ & Low & $\begin{array}{l}\text { Link to S1 } 4.2 \text { (training of } \\
\text { écogardes) and S5 (collision } \\
\text { monitoring) }\end{array}$ \\
\hline & $\begin{array}{l}4.2 \text { Assess, review and } \\
\text { adapt collision mitigation } \\
\text { plan and ensure no } \\
\text { 'problem power lines' } \\
\text { remain } \\
\end{array}$ & $\star \star \star$ & By 2020 & $\begin{array}{l}\text { Project } \\
\text { Coordinator with } \\
\text { external partners }\end{array}$ & Medium & $\begin{array}{l}\text { Review monitoring results } \\
\text { to determine if any problem } \\
\text { power lines remain. Expertise } \\
\text { available in Europe }\end{array}$ \\
\hline \multirow[t]{3}{*}{$\begin{array}{l}\text { 5. By 2020, the } \\
\text { negative impacts of } \\
\text { road, rail and other } \\
\text { infrastructure are } \\
\text { diminished. }\end{array}$} & \begin{tabular}{|l|}
5.1 Review transport \\
networks and other \\
infrastructure, assess \\
their potential impacts and \\
develop mitigation options
\end{tabular} & $\star \star$ & $\begin{array}{l}\text { By 2017, } \\
\text { then } \\
\text { ongoing }\end{array}$ & $\begin{array}{l}\text { Project } \\
\text { Coordinator, } \\
\text { with input from } \\
\text { HCEFLCD / } \\
\text { GREPOM / METL } \\
\text { / ONCF / ADM; } \\
\text { CSIC / Bustard } \\
\text { SG to advise }\end{array}$ & Medium & $\begin{array}{l}\text { All aspects should be } \\
\text { considered, including } \\
\text { fragmentation of landscape } \\
\text { and disturbance, and budget. } \\
\text { CSIC has already carried out } \\
\text { useful analysis (Palacín et al. } \\
\text { 2016) }\end{array}$ \\
\hline & $\begin{array}{l}5.2 \text { Implement mitigation } \\
\text { options where all } \\
\text { infrastructure may } \\
\text { negatively impact Great } \\
\text { Bustards }\end{array}$ & $\begin{array}{l}\star \star \\
\text { (adapt to } \\
\text { results of } \\
5.1)\end{array}$ & $\begin{array}{l}\text { From } \\
\text { 2017, then } \\
\text { ongoing }\end{array}$ & $\begin{array}{l}\text { Project } \\
\text { Coordinator, } \\
\text { with input from } \\
\text { HCEFLCD / } \\
\text { GREPOM / METL } \\
\text { / ONCF / ADM; } \\
\text { CSIC / Bustard } \\
\text { SG to advise }\end{array}$ & $\begin{array}{l}\text { potentially } \\
\text { High }\end{array}$ & $\begin{array}{l}\text { Some high-speed rail lines } \\
\text { have high impacts in Spain; } \\
\text { after review (5.1) some } \\
\text { urgent actions may be } \\
\text { recommended }\end{array}$ \\
\hline & $\begin{array}{l}5.3 \text { Ensure effective } \\
\text { independent ElAs are } \\
\text { carried out before all future } \\
\text { developments }\end{array}$ & $\star \star$ & 2016-2025 & $\begin{array}{l}\text { Project } \\
\text { Coordinator } \\
\text { /HCEFLCD / } \\
\text { GREPOM } \\
\end{array}$ & Low & $\begin{array}{l}\text { An ongoing activity; project } \\
\text { will need to build up lobbying } \\
\text { capacity and forge links }\end{array}$ \\
\hline
\end{tabular}




\begin{tabular}{|c|c|c|c|c|c|c|}
\hline $\begin{array}{l}\text { Strategic } \\
\text { Objective }\end{array}$ & Action & Priority & Timescale & $\begin{array}{l}\text { Organisations } \\
\text { / persons } \\
\text { responsible }\end{array}$ & $\begin{array}{l}\text { Cost (Low, } \\
\text { Medium, } \\
\text { High) }\end{array}$ & Notes \\
\hline \multicolumn{7}{|c|}{ S3 - Secure habitat in key bustard areas } \\
\hline \multicolumn{7}{|c|}{$\begin{array}{l}\text { LTO By 2025, Great Bustards are breeding successfully in Araoua and Tleta-Rissana and have returned to at least two additional } \\
\text { lek areas. }\end{array}$} \\
\hline \multirow{3}{*}{$\begin{array}{l}\text { 1. By 2017, clear } \\
\text { new designations } \\
\text { have been } \\
\text { established and } \\
\text { formalised for } \\
\text { Araoua and Tleta- } \\
\text { Rissana based } \\
\text { on their status as } \\
\text { essential areas } \\
\text { for Great Bustard } \\
\text { survival in Morocco. }\end{array}$} & \begin{tabular}{|l|}
1.1 Review current \\
designations in relation to \\
protection level afforded \\
and core bustard areas and \\
draw up new boundaries / \\
proposals for designation \\
\end{tabular} & $\star \star \star$ & $2016 / 17$ & $\begin{array}{l}\text { HCEFLCD / } \\
\text { GREPOM }\end{array}$ & Medium & $\begin{array}{l}\text { HCEFLCD needs to lead } \\
\text { this process with strong } \\
\text { involvement of its regional } \\
\text { offices }\end{array}$ \\
\hline & $\begin{array}{l}1.2 \text { Hold a series of } \\
\text { stakeholder meetings in } \\
\text { Araoua and Tleta-Rissana } \\
\text { to discuss and decide upon } \\
\text { appropriate designations }\end{array}$ & $\star \star \star$ & $2016 / 17$ & $\begin{array}{l}\text { Project } \\
\text { Coordinator } \\
\text { / HCEFLCD / } \\
\text { GREPOM }\end{array}$ & Medium & $\begin{array}{l}\text { Local stakeholder agreement } \\
\text { will be essential, and } \\
\text { stakeholders must have an } \\
\text { opportunity to influence plans }\end{array}$ \\
\hline & \begin{tabular}{|l|}
1.3 Launch formal \\
designation process and \\
see through their adoption \\
into legislation.
\end{tabular} & $\star \star \star$ & 2017 & $\begin{array}{l}\text { Project } \\
\text { Coordinator } \\
\text { / HCEFLCD / } \\
\text { GREPOM }\end{array}$ & Low & $\begin{array}{l}\text { Binding designations are } \\
\text { needed that pass through } \\
\text { legislation / judicial process }\end{array}$ \\
\hline \multirow{3}{*}{$\begin{array}{l}\text { 2. By 2018, } \\
\text { mechanisms and } \\
\text { incentives are in } \\
\text { place to promote } \\
\text { the 'Plan Maroc } \\
\text { Vert' in all current } \\
\text { and former Great } \\
\text { Bustard lek areas. }\end{array}$} & $\begin{array}{l}2.1 \text { Inter-ministerial } \\
\text { meetings at regional } \\
\text { level to identify means } \\
\text { and incentives to actively } \\
\text { promote the 'Plan Maroc } \\
\text { Vert' in all bustard areas }\end{array}$ & $\star \star$ & 2016-2017 & $\begin{array}{l}\text { Project } \\
\text { Coordinator } \\
\text { / MAPM / } \\
\text { HCEFLCD }\end{array}$ & Low & $\begin{array}{l}\text { This activity should run } \\
\text { mostly in parallel with S3 } \\
\text { 1.1-1.3. The project will } \\
\text { work closely with MAPM at } \\
\text { national, regional and local } \\
\text { levels }\end{array}$ \\
\hline & $\begin{array}{l}\text { 2.2 Community-based } \\
\text { stakeholder meetings to } \\
\text { promote the 'Plan Maroc } \\
\text { Vert' }\end{array}$ & $\star \star$ & 2016-2017 & $\begin{array}{l}\text { Project } \\
\text { Coordinator } \\
\text { / MAPM / } \\
\text { HCEFLCD }\end{array}$ & Low & $\begin{array}{l}\text { Local stakeholder input is } \\
\text { essential; close engagement } \\
\text { of local government offices }\end{array}$ \\
\hline & $\begin{array}{l}2.3 \text { Mechanisms in } \\
\text { place for financial / other } \\
\text { incentives for retaining / } \\
\text { adopting traditional farming } \\
\text { methods }\end{array}$ & $\star \star$ & $\begin{array}{l}\text { By 2018, } \\
\text { thence } \\
\text { ongoing }\end{array}$ & $\begin{array}{l}\text { Project } \\
\text { Coordinator } \\
\text { / MAPM / } \\
\text { HCEFLCD }\end{array}$ & Low & $\begin{array}{l}\text { Incentives will be linked } \\
\text { closely to the strategy and } \\
\text { regional agricultural plans of } \\
\text { the Plan Maroc Vert }\end{array}$ \\
\hline \multirow{3}{*}{$\begin{array}{l}\text { 3. By 2018, } \\
\text { agreements are } \\
\text { being implemented } \\
\text { to secure a mosaic } \\
\text { of habitats that } \\
\text { benefit Great } \\
\text { Bustards in Araoua } \\
\text { and Tleta-Rissana. }\end{array}$} & $\begin{array}{l}\text { 3.1 Community stakeholder } \\
\text { meetings and extension in } \\
\text { Araoua and Tleta-Rissana } \\
\text { to engage / interest } \\
\text { farmers and shepherds in } \\
\text { bustard-friendly farming }\end{array}$ & $\star \star$ & 2016-2017 & $\begin{array}{l}\text { Project } \\
\text { Coordinator } \\
\text { / MAPM / } \\
\text { HCEFLCD }\end{array}$ & Medium & $\begin{array}{l}\text { This activity will run mostly in } \\
\text { parallel with S3 } 1.1-1.3 \text { and } \\
\text { 2.1-2.3. The project will work } \\
\text { closely with MAPM at the } \\
\text { local level; incentives need to } \\
\text { be identified }\end{array}$ \\
\hline & \begin{tabular}{|l|}
3.2 Agreements secured \\
with farmers / proprietors \\
in Araoua and Tleta- \\
Rissana to secure suitable \\
habitats for bustards, \\
including year-round cover \\
\end{tabular} & $\star \star$ & $2016-2018$ & $\begin{array}{l}\text { Project } \\
\text { Coordinator } \\
\text { / MAPM / } \\
\text { HCEFLCD }\end{array}$ & Medium & $\begin{array}{l}\text { Type of agreement to be } \\
\text { decided locally; agreements } \\
\text { should not carry punitive } \\
\text { elements but operate rather } \\
\text { through positive incentives }\end{array}$ \\
\hline & $\begin{array}{l}3.3 \text { Bustard-friendly } \\
\text { farming and grazing } \\
\text { methods are implemented } \\
\text { including minimising } \\
\text { disturbance, mowing } \\
\text { breeding fields later and } \\
\text { retaining year-round cover }\end{array}$ & $\star \star \star$ & $\begin{array}{l}\text { By 2018/19, } \\
\text { thence } \\
\text { ongoing }\end{array}$ & $\begin{array}{l}\text { Project } \\
\text { Coordinator } \\
\text { / MAPM / } \\
\text { HCEFLCD }\end{array}$ & High & $\begin{array}{l}\text { This is the main } \\
\text { implementing activity on the } \\
\text { ground for } \mathrm{S} 32 \text { and } 3 \text {, with } \\
\text { active habitat management } \\
\text { mainly by land proprietors / } \\
\text { owners }\end{array}$ \\
\hline
\end{tabular}




\begin{tabular}{|c|c|c|c|c|c|c|}
\hline $\begin{array}{l}\text { Strategic } \\
\text { Objective }\end{array}$ & Action & Priority & Timescale & $\begin{array}{l}\text { Organisations } \\
\text { / persons } \\
\text { responsible }\end{array}$ & \begin{tabular}{|l} 
Cost (Low, \\
Medium, \\
High)
\end{tabular} & Notes \\
\hline \multirow{3}{*}{$\begin{array}{l}\text { 4. By } 2020 \text {, } \\
\text { agreements have } \\
\text { been reached to } \\
\text { reinstate Tendafel, } \\
\text { Kanouat and } \\
\text { Chekbouchan as } \\
\text { potential lek areas } \\
\text { with appropriate } \\
\text { undisturbed habitat } \\
\text { available. }\end{array}$} & $\begin{array}{l}\text { 4.1 Community stakeholder } \\
\text { meetings in Tendafel, } \\
\text { Kanouat and Chekbouchan } \\
\text { to promote and discuss } \\
\text { bustard-friendly farming }\end{array}$ & $\star$ & 2018-2019 & $\begin{array}{l}\text { Project } \\
\text { Coordinator } \\
\text { / MAPM / } \\
\text { HCEFLCD }\end{array}$ & Low & $\begin{array}{l}\text { This activity will run follow on } \\
\text { from S3 2.1-2.3. The project } \\
\text { will work closely with MAPM } \\
\text { at the local level; incentives } \\
\text { need to be identified }\end{array}$ \\
\hline & $\begin{array}{l}\text { 4.2 Agreements secured } \\
\text { with farmers / proprietors } \\
\text { in Tendafel, Kanouat and } \\
\text { Chekbouchan to secure } \\
\text { suitable habitats for } \\
\text { bustards, including year- } \\
\text { round cover } \\
\end{array}$ & $\star$ & $2018-2019$ & $\begin{array}{l}\text { Project } \\
\text { Coordinator } \\
\text { / MAPM / } \\
\text { HCEFLCD }\end{array}$ & Low & $\begin{array}{l}\text { Type of agreement to be } \\
\text { decided locally; agreements } \\
\text { should not carry punitive } \\
\text { elements but operate rather } \\
\text { through positive incentives }\end{array}$ \\
\hline & $\begin{array}{l}\text { 4.3 Bustard-friendly } \\
\text { farming and grazing } \\
\text { methods are implemented } \\
\text { including minimising } \\
\text { disturbance, mowing } \\
\text { breeding areas later and } \\
\text { retaining year-round cover }\end{array}$ & $\star$ & $\begin{array}{l}\text { By 2020, } \\
\text { thence } \\
\text { ongoing }\end{array}$ & $\begin{array}{l}\text { Project } \\
\text { Coordinator } \\
\text { / MAPM / } \\
\text { HCEFLCD }\end{array}$ & High & $\begin{array}{l}\text { Habitat management mainly } \\
\text { by land proprietors / owners }\end{array}$ \\
\hline \multicolumn{7}{|c|}{ S4 - Strengthen awareness and valuation } \\
\hline \multicolumn{7}{|c|}{$\begin{array}{l}\text { LTO By 2025, rural communities in northwest Morocco are benefiting from an increasing population of Great Bustards through } \\
\text { sustainable economic enterprises. }\end{array}$} \\
\hline \multirow{5}{*}{$\begin{array}{l}\text { 1. By 2017, } \\
\text { inhabitants in } \\
\text { Araoua and Tleta- } \\
\text { Rissana are aware } \\
\text { about the vital role } \\
\text { of their land to save } \\
\text { the Great Bustard } \\
\text { in Morocco, about } \\
\text { new conservation } \\
\text { measures } \\
\text { underway and the } \\
\text { need to minimise } \\
\text { disturbance. }\end{array}$} & $\begin{array}{l}\text { 1.1 Devise and launch } \\
\text { an awareness campaign } \\
\text { throughout the key bustard } \\
\text { areas. } \\
\end{array}$ & $\star \star \star$ & $\begin{array}{l}2016 / 17 \text {, } \\
\text { thence } \\
\text { ongoing }\end{array}$ & $\begin{array}{l}\text { Project } \\
\text { Coordinator }\end{array}$ & Medium & $\begin{array}{l}\text { Target groups should include } \\
\text { land managers, farmers, } \\
\text { shepherds, local decision } \\
\text { makers and young people } \\
\end{array}$ \\
\hline & $\begin{array}{l}1.2 \text { Establish community- } \\
\text { based 'Great Bustard } \\
\text { associations' in Araoua and } \\
\text { Tleta-Rissana }\end{array}$ & $\star \star \star$ & $2016 / 17$ & $\begin{array}{l}\text { Project } \\
\text { Coordinator }\end{array}$ & Low & $\begin{array}{l}\text { Associations should be } \\
\text { community-led, but with } \\
\text { some resources available for } \\
\text { functioning via the project }\end{array}$ \\
\hline & $\begin{array}{l}1.3 \text { Hold public meetings } \\
\text { and events (e.g. Great } \\
\text { Bustard Days) focused on } \\
\text { the Great Bustard and on } \\
\text { project activities }\end{array}$ & $\star \star$ & $\begin{array}{l}2016-2017, \\
\text { thence } \\
\text { ongoing }\end{array}$ & $\begin{array}{l}\text { Project } \\
\text { Coordinator }\end{array}$ & Medium & $\begin{array}{l}\text { Local communities need } \\
\text { to be strongly aware of the } \\
\text { project and be updated about } \\
\text { progress }\end{array}$ \\
\hline & $\begin{array}{l}\text { 1.4 Develop agreements } \\
\text { and actions to minimise } \\
\text { disturbance to bustards, } \\
\text { especially from farm and } \\
\text { feral dogs }\end{array}$ & $\star \star$ & $\begin{array}{l}2017, \\
\text { thence } \\
\text { ongoing }\end{array}$ & $\begin{array}{l}\text { Project } \\
\text { Coordinator }\end{array}$ & Medium & $\begin{array}{l}\text { Disturbance should be kept to } \\
\text { a minimum, especially during } \\
\text { courtship and breeding, and } \\
\text { steps taken to reduce the } \\
\text { threat of dogs (as potential } \\
\text { predators) }\end{array}$ \\
\hline & $\begin{array}{l}1.5 \text { Investigate options to } \\
\text { establish a Great Bustard } \\
\text { 'centre', with interpretation } \\
\text { and other facilities and sale } \\
\text { of products }\end{array}$ & $\star$ & 2016-2018 & $\begin{array}{l}\text { Project } \\
\text { Coordinator / } \\
\text { Great Bustard } \\
\text { associations } \\
\text { / GREPOM / } \\
\text { HCEFLCD }\end{array}$ & $\begin{array}{l}\text { Medium } \\
\text { (High for } \\
\text { establishing } \\
\text { centre) }\end{array}$ & $\begin{array}{l}\text { Consider alongside need for } \\
\text { a project centre (S1 1.4), also } \\
\text { potential for bird-viewing } \\
\text { hides. Potential venue for sale } \\
\text { of products from S4 } 3 \text { and } 4\end{array}$ \\
\hline \multirow{3}{*}{$\begin{array}{l}\text { 2. By 2019, } \\
\text { awareness of } \\
\text { Great Bustard } \\
\text { conservation } \\
\text { measures is } \\
\text { entrenched within } \\
\text { public institutions, } \\
\text { especially schools. }\end{array}$} & $\begin{array}{l}2.1 \text { Develop materials } \\
\text { and methods for effective } \\
\text { bustard awareness } \\
\text { activities in local schools } \\
\end{array}$ & $\star \star$ & $\begin{array}{l}2016 / 17, \\
\text { thence } \\
\text { ongoing and } \\
\text { adapting } \\
\end{array}$ & $\begin{array}{l}\text { Project } \\
\text { Coordinator, } \\
\text { local educators }\end{array}$ & Medium & $\begin{array}{l}\text { Some teachers have already } \\
\text { been active in conservation } \\
\text { activities and Great Bustard } \\
\text { awareness }\end{array}$ \\
\hline & \begin{tabular}{|l|}
2.2 Hold meetings with \\
relevant government \\
institutions and offices, e.g. \\
agriculture, development, \\
infrastructure
\end{tabular} & $\star \star$ & $\begin{array}{l}2016-2017, \\
\text { thence } \\
\text { ongoing }\end{array}$ & $\begin{array}{l}\text { Project } \\
\text { Coordinator }\end{array}$ & Low & $\begin{array}{l}\text { The project's presence } \\
\text { needs to be felt keenly in } \\
\text { local government offices } \\
\text { and be known by staff, e.g. } \\
\text { agricultural extension officers }\end{array}$ \\
\hline & $\begin{array}{l}2.3 \text { Build Great Bustard } \\
\text { initiatives into institutes of } \\
\text { higher learning (universities } \\
\text { / colleges) }\end{array}$ & $\star \star$ & $\begin{array}{l}\text { 2017-2019, } \\
\text { thence } \\
\text { ongoing }\end{array}$ & $\begin{array}{l}\text { Project } \\
\text { Coordinator / } \\
\text { GREPOM / ENA }\end{array}$ & Low & $\begin{array}{l}\text { The project should attract } \\
\text { studies from universities, and } \\
\text { colleges, such as ENA (in } \\
\text { Meknès) }\end{array}$ \\
\hline
\end{tabular}




\begin{tabular}{|c|c|c|c|c|c|c|}
\hline $\begin{array}{l}\text { Strategic } \\
\text { Objective }\end{array}$ & Action & Priority & Timescale & $\begin{array}{l}\text { Organisations } \\
\text { / persons } \\
\text { responsible }\end{array}$ & $\begin{array}{l}\text { Cost (Low, } \\
\text { Medium, } \\
\text { High) }\end{array}$ & Notes \\
\hline \multirow{3}{*}{$\begin{array}{l}\text { 3. By 2020, a } \\
\text { community- } \\
\text { based economic } \\
\text { incentives } \\
\text { programme is } \\
\text { underway, likely to } \\
\text { include branding } \\
\text { of 'Great Bustard' } \\
\text { products. }\end{array}$} & $\begin{array}{l}\text { 3.1 Through active } \\
\text { community consultation } \\
\text { and lead, develop } \\
\text { sustainable economic } \\
\text { incentives based around } \\
\text { the Great Bustard }\end{array}$ & $\star \star \star$ & $2017-2018$ & $\begin{array}{l}\text { Great Bustard } \\
\text { associations } \\
\text { / Project } \\
\text { Coordinator, in } \\
\text { consultation } \\
\text { with MAPM and } \\
\text { HCEFLCD } \\
\end{array}$ & Medium & $\begin{array}{l}\text { A series of meetings will } \\
\text { be needed to identify the } \\
\text { most promising and best- } \\
\text { supported incentives }\end{array}$ \\
\hline & $\begin{array}{l}\text { 3.2 Encourage Great } \\
\text { Bustard branding linked } \\
\text { to products of sustainable } \\
\text { 'bustard-friendly' farming }\end{array}$ & $\star \star$ & $2017-2019$ & $\begin{array}{l}\text { Great Bustard } \\
\text { associations } \\
\text { / Project } \\
\text { Coordinator, in } \\
\text { consultation } \\
\text { with MAPM and } \\
\text { HCEFLCD }\end{array}$ & Medium & $\begin{array}{l}\text { Branding is one definite } \\
\text { option that deserves special } \\
\text { attention, linked to Plan } \\
\text { Maroc Vert products from } \\
\text { bustard areas }\end{array}$ \\
\hline & $\begin{array}{l}\text { 3.3 Launch Great } \\
\text { Bustard products and } \\
\text { build awareness (market } \\
\text { outreach, community buy- } \\
\text { in etc.) }\end{array}$ & $\star \star$ & $\begin{array}{l}\text { 2019- 2020, } \\
\text { thence } \\
\text { ongoing }\end{array}$ & $\begin{array}{l}\text { Great Bustard } \\
\text { associations } \\
\text { / Project } \\
\text { Coordinator, in } \\
\text { consultation } \\
\text { with MAPM and } \\
\text { HCEFLCD }\end{array}$ & Medium & $\begin{array}{l}\text { Products will need good } \\
\text { marketing, with professional } \\
\text { support for this and other } \\
\text { aspects }\end{array}$ \\
\hline \multirow{4}{*}{$\begin{array}{l}\text { 4. By 2020, low- } \\
\text { level ecotourism } \\
\text { initiatives are } \\
\text { under operation } \\
\text { that feature Great } \\
\text { Bustards in their } \\
\text { itinerary. }\end{array}$} & $\begin{array}{l}4.1 \text { Explore options for low- } \\
\text { level tourism in Araoua that } \\
\text { features the Great Bustard }\end{array}$ & $\star$ & 2017 & $\begin{array}{l}\text { Project } \\
\text { Coordinator } \\
\text { / HCEFLCD / } \\
\text { GREPOM / CSIC } \\
\end{array}$ & Low & $\begin{array}{l}\text { Consider wider ecotourism } \\
\text { potential, e.g. culture (Zelis), } \\
\text { hiking, local products }\end{array}$ \\
\hline & $\begin{array}{l}\text { 4.2 Develop protocols and } \\
\text { guidelines for ecotourism }\end{array}$ & $\star$ & 2017 & $\begin{array}{l}\text { HCEFLCD / } \\
\text { GREPOM / CSIC }\end{array}$ & Low & $\begin{array}{l}\text { CSIC could provide good } \\
\text { advice from Spanish } \\
\text { experience }\end{array}$ \\
\hline & $\begin{array}{l}\text { 4.3 Build Great Bustard } \\
\text { into (northwest) Morocco } \\
\text { birding circuits }\end{array}$ & $\star$ & $\begin{array}{l}2018-2019, \\
\text { thence } \\
\text { ongoing }\end{array}$ & $\begin{array}{l}\text { HCEFLCD } \\
\text { / GREPOM } \\
\text { / Project } \\
\text { Coordinator }\end{array}$ & Low & $\begin{array}{l}\text { Birding is increasingly popular } \\
\text { in Morocco; strong potential } \\
\text { to promote the project area }\end{array}$ \\
\hline & $\begin{array}{l}4.4 \text { Establish mechanisms } \\
\text { for community benefits } \\
\text { from ecotourism operations }\end{array}$ & $\star$ & $\begin{array}{l}2019-2020 \text {, } \\
\text { thence } \\
\text { ongoing }\end{array}$ & $\begin{array}{l}\text { HCEFLCD } \\
\text { / GREPOM } \\
\text { / Project } \\
\text { Coordinator and } \\
\text { Great Bustard } \\
\text { associations }\end{array}$ & Low & $\begin{array}{l}\text { Need to ensure that all } \\
\text { ecotourism operations yield } \\
\text { community benefits }\end{array}$ \\
\hline \multicolumn{7}{|c|}{ S5 - Research and monitoring } \\
\hline \multicolumn{7}{|c|}{$\begin{array}{l}\text { LTO By 2025, effective research and monitoring of population trends, behaviour, movements, habitat requirements and other } \\
\text { parameters have yielded conservation solutions, enabling the Great Bustard population to increase. }\end{array}$} \\
\hline \multirow{3}{*}{$\begin{array}{l}\text { 1. 2016-2025: } \\
\text { Censuses of Great } \\
\text { Bustards (and sex } \\
\text { ratios) in Araoua } \\
\text { and Tleta-Rissana } \\
\text { are conducted } \\
\text { annually during } \\
\text { early spring, } \\
\text { and every three } \\
\text { years across all } \\
\text { leks to determine } \\
\text { population trends. }\end{array}$} & $\begin{array}{l}\text { 1.1 Develop protocols } \\
\text { and guidelines for Great } \\
\text { Bustard spring censuses }\end{array}$ & $\star \star$ & 2016 & $\begin{array}{l}\text { CSIC / GREPOM } \\
\text { / HCEFLCD }\end{array}$ & Low & $\begin{array}{l}\text { CSIC has strong experience } \\
\text { of organising the census, } \\
\text { with local coordination }\end{array}$ \\
\hline & $\begin{array}{l}1.2 \text { Conduct spring } \\
\text { censuses annually in } \\
\text { Araoua and Tleta-Rissana } \\
\text { and every three years } \\
\text { across all (former) leks }\end{array}$ & $\star \star \star$ & $\begin{array}{l}\text { Annually / } \\
\text { ongoing }\end{array}$ & $\begin{array}{l}\text { Project } \\
\text { Coordinator, with } \\
\text { guidance and } \\
\text { at times direct } \\
\text { involvement of } \\
\text { CSIC } \\
\end{array}$ & Medium & $\begin{array}{l}\text { Census teams to include } \\
\text { personnel of HCEFLCD, } \\
\text { GREPOM and local } \\
\text { écogardes; CSIC to continue } \\
\text { their support }\end{array}$ \\
\hline & $\begin{array}{l}\text { 1.3 Prepare concise annual } \\
\text { census reports with } \\
\text { analyses }\end{array}$ & $\star \star \star$ & $\begin{array}{l}\text { By May } \\
\text { each year }\end{array}$ & $\begin{array}{l}\text { Project } \\
\text { Coordinator }\end{array}$ & Low & $\begin{array}{l}\text { Reports need to be timely to } \\
\text { guide conservation action }\end{array}$ \\
\hline \multirow{2}{*}{$\begin{array}{l}\text { 2. 2016-2025: A } \\
\text { casualty transect } \\
\text { monitoring } \\
\text { programme is } \\
\text { established and } \\
\text { implemented, } \\
\text { to monitor bird } \\
\text { casualties caused } \\
\text { by power lines in all } \\
\text { lek areas. }\end{array}$} & $\begin{array}{l}2.1 \text { Develop a casualty } \\
\text { transect monitoring } \\
\text { programme and train } \\
\text { écogarde capacity to } \\
\text { implement monitoring }\end{array}$ & $\star \star$ & $2016 / 17$ & $\begin{array}{l}\text { CSIC / GREPOM } \\
\text { / HCEFLCD }\end{array}$ & Low & $\begin{array}{l}\text { CSIC has strong experience } \\
\text { of carrying out such } \\
\text { monitoring in Spain, and } \\
\text { could provide technical } \\
\text { support }\end{array}$ \\
\hline & $\begin{array}{l}2.2 \text { Implement monitoring } \\
\text { according to the casualty } \\
\text { transect monitoring } \\
\text { programme }\end{array}$ & $\star \star \star$ & $\begin{array}{l}\text { Ongoing, } \\
\text { according to } \\
\text { timetable in } \\
\text { programme }\end{array}$ & $\begin{array}{l}\text { Project } \\
\text { Coordinator, with } \\
\text { guidance of CSIC }\end{array}$ & Medium & $\begin{array}{l}\text { Monitoring to be conducted } \\
\text { by local écogardes; CSIC to } \\
\text { continue their support }\end{array}$ \\
\hline
\end{tabular}




\begin{tabular}{|c|c|c|c|c|c|c|}
\hline $\begin{array}{l}\text { Strategic } \\
\text { Objective }\end{array}$ & Action & Priority & Timescale & $\begin{array}{l}\text { Organisations } \\
\text { / persons } \\
\text { responsible }\end{array}$ & $\begin{array}{l}\text { Cost (Low, } \\
\text { Medium, } \\
\text { High) }\end{array}$ & Notes \\
\hline \multirow{3}{*}{$\begin{array}{l}\text { 3. By 2017, a } \\
\text { programme of } \\
\text { integrated research } \\
\text { is established to } \\
\text { investigate the } \\
\text { conservation status } \\
\text { of Great Bustards } \\
\text { throughout the year, } \\
\text { including behaviour, } \\
\text { movements } \\
\text { and habitat } \\
\text { requirements. }\end{array}$} & $\begin{array}{l}3.1 \text { Hold a small technical } \\
\text { workshop to develop } \\
\text { an integrated research } \\
\text { programme and identify } \\
\text { actors }\end{array}$ & $\star \star$ & $2016 / 17$ & $\begin{array}{l}\text { HCEFLCD / } \\
\text { GREPOM / CSIC }\end{array}$ & Medium & $\begin{array}{l}\text { Engage universities and } \\
\text { colleges (e.g. agricultural } \\
\text { college), alongside existing } \\
\text { partners }\end{array}$ \\
\hline & $\begin{array}{l}\text { 3.2 Launch / circulate } \\
\text { an integrated research } \\
\text { programme and liaise with } \\
\text { partners to fund-raise for } \\
\text { its implementation and } \\
\text { adopt components of the } \\
\text { plan }\end{array}$ & $\star \star$ & 2017 & $\begin{array}{l}\text { HCEFLCD / } \\
\text { GREPOM / } \\
\text { CSIC; input from } \\
\text { Bustard SG }\end{array}$ & Low & $\begin{array}{l}\text { Consider building in local } \\
\text { PhD positions for longer-term } \\
\text { studies of bustard behaviour } \\
\text { / movements, also socio- } \\
\text { economic research linked to } \\
\text { traditional agriculture }\end{array}$ \\
\hline & $\begin{array}{l}3.3 \text { Launch research } \\
\text { activities as separate } \\
\text { components }\end{array}$ & $\star \star$ & $\begin{array}{l}\text { By 2017/18, } \\
\text { thence } \\
\text { ongoing }\end{array}$ & $\begin{array}{l}\text { HCEFLCD } \\
\text { / GREPOM } \\
\text { / Research } \\
\text { partners } \\
\end{array}$ & \begin{tabular}{|l} 
Medium \\
- High \\
(depends on \\
activities) \\
\end{tabular} & $\begin{array}{l}\text { Separating components } \\
\text { may be more sustainable } \\
\text { and encourage diversity of } \\
\text { partners }\end{array}$ \\
\hline \multirow[t]{2}{*}{$\begin{array}{l}\text { 4. By 2018, all } \\
\text { identified actual } \\
\text { and potential } \\
\text { threats are being } \\
\text { monitored. }\end{array}$} & $\begin{array}{l}4.1 \text { Ensure all potential } \\
\text { threats are monitored } \\
\text { throughout the year in } \\
\text { Araoua and Tleta-Rissana, } \\
\text { including changes in land } \\
\text { use and infrastructure }\end{array}$ & $\star \star \star$ & $\begin{array}{l}\text { By 2017/18, } \\
\text { thence } \\
\text { ongoing }\end{array}$ & $\begin{array}{l}\text { Project } \\
\text { Coordinator, with } \\
\text { écogardes }\end{array}$ & Medium & $\begin{array}{l}\text { As far as possible, monitor } \\
\text { out-of-season hunting, } \\
\text { disturbance, loss of cover, } \\
\text { collisions, etc. Also monitor } \\
\text { changes in land use (farms } \\
\text { / farming practices) and } \\
\text { infrastructure (power lines / } \\
\text { transport links) } \\
\end{array}$ \\
\hline & $\begin{array}{l}\text { 4.2 Monitor potential } \\
\text { threats through site visits } \\
\text { and interviews in five other } \\
\text { (former) leks }\end{array}$ & $\star \star$ & $\begin{array}{l}\text { By 2017/18, } \\
\text { thence } \\
\text { ongoing }\end{array}$ & $\begin{array}{l}\text { Project } \\
\text { Coordinator, with } \\
\text { écogardes }\end{array}$ & Medium & $\begin{array}{l}\text { As far as possible, monitor } \\
\text { out-of-season hunting, } \\
\text { disturbance, loss of cover, } \\
\text { collisions, etc. }\end{array}$ \\
\hline \multirow[t]{3}{*}{$\begin{array}{l}\text { 5. By } 2018 \text {, there } \\
\text { is good local } \\
\text { capacity to conduct } \\
\text { censuses and } \\
\text { research. }\end{array}$} & $\begin{array}{l}5.1 \text { Organise and carry } \\
\text { out a training programme } \\
\text { for écogardes and others } \\
\text { directly involved in the } \\
\text { project in census and } \\
\text { components of research }\end{array}$ & $\star \star \star$ & $\begin{array}{l}\text { Develop } \\
\text { programme } \\
\text { in 2017; } \\
\text { conduct } \\
\text { annual } \\
\text { training } \\
\text { thence }\end{array}$ & $\begin{array}{l}\text { Project } \\
\text { Coordinator, } \\
\text { with support } \\
\text { from HCEFLCD / } \\
\text { GREPOM / CSIC }\end{array}$ & Medium & $\begin{array}{l}\text { Strong local capacity is } \\
\text { needed for a sustainable } \\
\text { programme of censuses } \\
\text { and research; écogardes in } \\
\text { particular need reliable field } \\
\text { skills }\end{array}$ \\
\hline & $\begin{array}{l}5.2 \text { Ensure écogardes and } \\
\text { other trainees participate } \\
\text { in censuses and other } \\
\text { research activities }\end{array}$ & $\star \star \star$ & $\begin{array}{l}2017 \\
\text { onwards }\end{array}$ & $\begin{array}{l}\text { Project } \\
\text { Coordinator }\end{array}$ & Low & $\begin{array}{l}\text { Multi-agency teams with } \\
\text { good involvement of local } \\
\text { stakeholders }\end{array}$ \\
\hline & $\begin{array}{l}\text { 5.3 Provide advanced } \\
\text { training for Coordinator } \\
\text { or research assistant for } \\
\text { effective technical capacity } \\
\text { within the project }\end{array}$ & $\star \star$ & $\begin{array}{l}2017 \\
\text { onwards; } \\
\text { certification } \\
\text { by } 2018 / 19\end{array}$ & $\begin{array}{l}\text { Project } \\
\text { Coordinator, } \\
\text { with support } \\
\text { from HCEFLCD / } \\
\text { GREPOM / CSIC }\end{array}$ & Medium & $\begin{array}{l}\text { Advance research capacity } \\
\text { on the ground is necessary } \\
\text { to enable an efficient and } \\
\text { adaptable conservation } \\
\text { programme }\end{array}$ \\
\hline \multicolumn{7}{|c|}{ S6 - Sustainable funding } \\
\hline \multicolumn{7}{|c|}{ LTO: By 2025, Great Bustard conservation in Morocco is assured through secured sustainable financing mechanisms. } \\
\hline \multirow{3}{*}{$\begin{array}{l}\text { 1. In 2016, the } \\
\text { agreement } \\
\text { between HCEFLCD } \\
\text { and the LGV is } \\
\text { functional and } \\
\text { funds are available } \\
\text { for immediate } \\
\text { mitigating actions. }\end{array}$} & $\begin{array}{l}\text { 1.1 Realise the HCEFLCD- } \\
\text { LGV agreement and link } \\
\text { directly to this action plan } \\
\text { for implementation of } \\
\text { urgent actions }\end{array}$ & $\star \star \star$ & $\begin{array}{l}2016 ; \\
\text { secure } \\
\text { funds up to } \\
\text { end } 2018 \text { at } \\
\text { least }\end{array}$ & HCEFLCD / LGV & Low & $\begin{array}{l}\text { This agreement is signed but } \\
\text { not being implemented yet }\end{array}$ \\
\hline & $\begin{array}{l}1.2 \text { Establish project } \\
\text { board or steering group to } \\
\text { monitor actions and use } \\
\text { of funds }\end{array}$ & $\star \star$ & 2016 & $\begin{array}{l}\text { HCEFLCD / } \\
\text { GREPOM / LGV }\end{array}$ & Low & $\begin{array}{l}\text { A group should be set up to } \\
\text { guide project management } \\
\text { and wise use of funds }\end{array}$ \\
\hline & $\begin{array}{l}\text { 1.3 Prepare information } \\
\text { materials and reports } \\
\text { highlighting the } \\
\text { collaboration and support } \\
\text { of LGV }\end{array}$ & $\star \star$ & 2016-2018 & $\begin{array}{l}\text { Project } \\
\text { Coordinator }\end{array}$ & Low & $\begin{array}{l}\text { Efficient information sharing } \\
\text { and reporting may attract } \\
\text { follow-up support }\end{array}$ \\
\hline
\end{tabular}




\begin{tabular}{|c|c|c|c|c|c|c|}
\hline $\begin{array}{l}\text { Strategic } \\
\text { Objective }\end{array}$ & Action & Priority & Timescale & $\begin{array}{l}\text { Organisations } \\
\text { / persons } \\
\text { responsible }\end{array}$ & \begin{tabular}{|l} 
Cost (Low, \\
Medium, \\
High)
\end{tabular} & Notes \\
\hline \multirow{3}{*}{$\begin{array}{l}\text { 2. By 2017, } \\
\text { additional external } \\
\text { funds and } \\
\text { partnerships are } \\
\text { in place, especially } \\
\text { to address priority } \\
\text { issues of poaching } \\
\text { and collisions. }\end{array}$} & $\begin{array}{l}2.1 \text { Circulate the action } \\
\text { plan and approach } \\
\text { potential donors for support } \\
\text { of priority actions } \\
\end{array}$ & $\star \star \star$ & $\begin{array}{l}2016 \text { and } \\
2017, \\
\text { ongoing }\end{array}$ & $\begin{array}{l}\text { Project } \\
\text { Coordinator }\end{array}$ & Low & $\begin{array}{l}\text { Wide targeted circulation of } \\
\text { the action plan in English and } \\
\text { French should yield success }\end{array}$ \\
\hline & $\begin{array}{l}2.2 \text { Investigate options for } \\
\text { follow-up support through } \\
\text { the IUCN Centre for } \\
\text { Mediterranean Cooperation }\end{array}$ & $\star \star$ & 2016-2017 & $\begin{array}{l}\text { Project } \\
\text { Coordinator }\end{array}$ & Low & $\begin{array}{l}\text { There should be some } \\
\text { institutional interest of } \\
\text { partners that supported the } \\
\text { development of the action } \\
\text { plan }\end{array}$ \\
\hline & $\begin{array}{l}2.3 \text { Investigate options for } \\
\text { twinning arrangements, } \\
\text { e.g. with Great Bustard } \\
\text { areas in Spain }\end{array}$ & $\star$ & 2016-2017 & $\begin{array}{l}\text { Project } \\
\text { Coordinator/ } \\
\text { GREPOM }\end{array}$ & Low & $\begin{array}{l}\text { Twinning arrangements have } \\
\text { awareness and exchange } \\
\text { benefits, but may also } \\
\text { promote additional support } \\
\text { and finance }\end{array}$ \\
\hline $\begin{array}{l}\text { 3. By 2018, } \\
\text { government } \\
\text { commitments are } \\
\text { secured for long- } \\
\text { term financing of } \\
\text { local surveillance. }\end{array}$ & $\begin{array}{l}\text { 3.1 During the LGV support } \\
\text { phase, hold meetings } \\
\text { to secure governmental } \\
\text { commitment of finances } \\
\text { beyond } 2018\end{array}$ & $\star \star \star$ & 2016-2018 & $\begin{array}{l}\text { Project } \\
\text { Coordinator } \\
\text { / HCEFLCD / } \\
\text { GREPOM }\end{array}$ & Low & $\begin{array}{l}\text { Government financial support } \\
\text { is especially relevant for } \\
\text { the coordination unit and } \\
\text { écogardes }\end{array}$ \\
\hline \multirow[t]{2}{*}{$\begin{array}{l}\text { 4. By 2020, } \\
\text { Great Bustard } \\
\text { conservation is } \\
\text { fully integrated into } \\
\text { annual government } \\
\text { budgets. }\end{array}$} & $\begin{array}{l}4.1 \text { Hold meetings and } \\
\text { develop a framework } \\
\text { and annual budget for } \\
\text { integrating Great Bustard } \\
\text { conservation into annual } \\
\text { government budgets } \\
\end{array}$ & $\star \star$ & $2017-2019$ & $\begin{array}{l}\text { Project } \\
\text { Coordinator } \\
\text { /HCEFLCD / } \\
\text { GREPOM }\end{array}$ & Medium & $\begin{array}{l}\text { Meetings should involve } \\
\text { different ministries, with } \\
\text { HCEFLCD taking the lead }\end{array}$ \\
\hline & $\begin{array}{l}\text { 4.2 Formally adopt Great } \\
\text { Bustard conservation into } \\
\text { government agenda and } \\
\text { budget }\end{array}$ & $\star \star \star$ & $\begin{array}{l}\text { 2020, then } \\
\text { ongoing }\end{array}$ & HCEFLCD & Low & $\begin{array}{l}\text { Government should adopt the } \\
\text { management of designated } \\
\text { areas, surveillance and } \\
\text { monitoring, which are all } \\
\text { required long-term actions }\end{array}$ \\
\hline
\end{tabular}

\section{Notes}

- Priority scale. All actions described are of importance, according to the rankings below:

$\begin{array}{cll}\star \star \star \star & \text { Urgent High priority action: } & \text { of critical importance; needs immediate action, essential for success } \\ \star \star \star & \text { High Priority action: } & \text { seriously important action, necessary for success } \\ \star \star & \text { Priority action: } & \text { important action, highly beneficial for success } \\ \star & \text { Moderate Priority action: } & \text { useful action, beneficial for success }\end{array}$

- Costs have been divided into categories, which have the following approximate values:

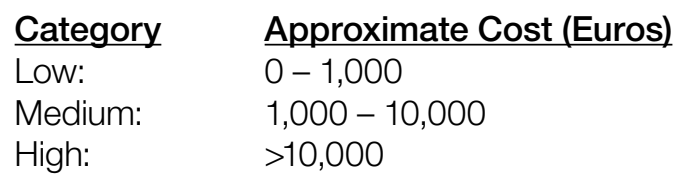

These costs require review when starting up implementation of the action plan.

- The action plan should be reviewed every three years, i.e. in 2019 and 2022, with a review and development of a new plan early 2025.

- Establishment of a steering group is mentioned under action S6 1.2. It will be necessary to establish a group to provide technical and management guidance to the project. This could be a coordination committee, steering group or advisory board. The remit and make-up of the group should be decided locally during year 1. Most such groups become too costly to run and inefficient if they have more than ten members. 


\section{Monitoring Plan: Indicators and Means of Verification}

Monitoring and evaluation are important components of any plan or project. Here, indicators and means of verification are presented for each strategic objective. The plan should be a flexible document, such that where some strategic objectives are not being met, then there is scope for review to ensure that objectives are met. Of course, the action plan is a plan and not a fully resourced project, so some objectives may not be met if resources are not identified to finance or support the proposed actions. Regular, e.g. annual monitoring of the action plan guided by the indicators and means of verification given will help the steering group (or equivalent) to prioritise new approaches for funding or other support.

Table 5. Indicators and Means of Verification for Action Plan Strategic Objectives

\begin{tabular}{|c|c|c|}
\hline Strategic Objective & Indicators & Means of Verification \\
\hline \multicolumn{3}{|l|}{ S1 - Establish surveillance capacity } \\
\hline \multicolumn{3}{|c|}{$\begin{array}{l}\text { LTO By 2025, effective surveillance has and in-situ monitoring enabled the Great Bustard population in Morocco to increase by } \\
25 \% .\end{array}$} \\
\hline $\begin{array}{l}\text { 1. By } 2017 \text {, local écogardes are recruited backed } \\
\text { up by an effective coordination unit. }\end{array}$ & $\begin{array}{l}\text { By 2018, effective well-resourced surveillance } \\
\text { capacity in place, with coordination centre, unit } \\
\text { and écogardes }\end{array}$ & $\begin{array}{l}\text { - Physical presence of centre, coordination staff } \\
\text { and écogardes } \\
\text { - Terms of Reference and work programmes } \\
\text { - Surveillance reports }\end{array}$ \\
\hline $\begin{array}{l}\text { 2. By 2018, all leks are safeguarded from illegal } \\
\text { hunters and legislation implemented. }\end{array}$ & $\begin{array}{l}\text { By 2018, leks functioning in Araoua and Tleta- } \\
\text { Rissana without disturbance from hunters }\end{array}$ & $\begin{array}{l}\text { - Spring census reports } \\
\text { - Surveillance reports }\end{array}$ \\
\hline $\begin{array}{l}\text { 3. By 2018, all communities and hunters active } \\
\text { in northwest Morocco are fully aware of the } \\
\text { protected status of Great Bustard. }\end{array}$ & $\begin{array}{l}\text { Wide awareness of the Great Bustard status, } \\
\text { especially in hunting circles }\end{array}$ & $\begin{array}{l}\text { - Project reports / meeting reports } \\
\text { - Interviews with hunters } \\
\text { - Awareness materials targeted at hunters }\end{array}$ \\
\hline $\begin{array}{l}\text { 4. By } 2020 \text {, sustainable mechanisms are in } \\
\text { place to minimise collisions and control illegal } \\
\text { wildlife hunting in Araoua and Tleta-Rissana, } \\
\text { and to prevent Great Bustard poaching in all } \\
\text { areas. }\end{array}$ & $\begin{array}{l}\text { By 2020, well-controlled hunting operations } \\
\text { in northwest Morocco, with absence of illegal } \\
\text { hunting in all Great Bustard areas }\end{array}$ & $\begin{array}{l}\text { - Local hunting groups reports / agreements } \\
\text { - Surveillance and census reports } \\
\text { - Training records }\end{array}$ \\
\hline \multicolumn{3}{|c|}{ S2 - Minimise power line collisions and impacts from other infrastructure } \\
\hline \multicolumn{3}{|c|}{$\begin{array}{l}\text { LTO By 2025, the risk of Great Bustard collision with power lines is minimised and the impacts of transport and other } \\
\text { infrastructure diminished. }\end{array}$} \\
\hline $\begin{array}{l}\text { 1. By 2017, agreements are in place to remove } \\
\text { or mark existing power lines in Araoua and } \\
\text { Tleta-Rissana and that no new power lines will } \\
\text { traverse leks. }\end{array}$ & $\begin{array}{l}\text { Permanent absence of power lines in core areas } \\
\text { of Araoua and Tleta-Rissana, with all other } \\
\text { power lines carrying anti-collision devices }\end{array}$ & $\begin{array}{l}\text { - Signed convention with delineation of 'no } \\
\text { power line zones' } \\
\text { - Verify absence of power lines and presence of } \\
\text { markers through site visits }\end{array}$ \\
\hline $\begin{array}{l}\text { 2. By 2018, the main 'problem power lines' in } \\
\text { Araoua and Tleta-Rissana have been removed, } \\
\text { with markers placed on all other lines within } \\
\text { bustard habitat in these areas. }\end{array}$ & $\begin{array}{l}\text { By 2018, problem power lines removed, no new } \\
\text { power lines installed and markers present on all } \\
\text { other power lines contributing to minimised risk } \\
\text { of collisions for Great Bustards and other birds }\end{array}$ & $\begin{array}{l}\text { - Verify removal of problem power lines, } \\
\text { absence of new power lines and presence } \\
\text { of markers through site visits to Araoua and } \\
\text { Tleta-Rissana }\end{array}$ \\
\hline $\begin{array}{l}\text { 3. By 2019, agreements are in place to minimise } \\
\text { potential risk of collisions in Tendafel, Kanouat } \\
\text { and Chekbouchan. }\end{array}$ & $\begin{array}{l}\text { Agreement to mitigate collisions in place by } \\
2019\end{array}$ & $\begin{array}{l}\text { - Signed convention / agreement with plans for } \\
\text { mitigating measures }\end{array}$ \\
\hline $\begin{array}{l}\text { 4. By 2020, collisions of Great Bustards with } \\
\text { power lines are no longer a threat in key areas. }\end{array}$ & $\begin{array}{l}\text { No collisions of Great Bustards with power lines } \\
\text { in key areas annually }\end{array}$ & - Surveillance / monitoring reports \\
\hline $\begin{array}{l}\text { 5. By } 2020 \text {, the negative impacts of road, rail } \\
\text { and other infrastructure are diminished. }\end{array}$ & $\begin{array}{l}\text { By 2017, mitigation measures planned } \\
\text { or in place on existing networks, where } \\
\text { recommended; } \\
\text { ElAs mandatory and carried out for all new } \\
\text { developments, with Great Bustard issues taken } \\
\text { into account }\end{array}$ & $\begin{array}{l}\text { - Project and transport convention reports } \\
\text { - Site visits with staff } \\
\text { - Published EIAs }\end{array}$ \\
\hline
\end{tabular}




\begin{tabular}{|c|c|c|}
\hline Strategic Objective & Indicators & Means of Verification \\
\hline \multicolumn{3}{|l|}{ S3 - Secure habitat in key bustard areas } \\
\hline \multicolumn{3}{|c|}{$\begin{array}{l}\text { LTO By 2025, Great Bustards are breeding successfully in Araoua and Tleta-Rissana and have returned to at least two additional } \\
\text { lek areas. }\end{array}$} \\
\hline $\begin{array}{l}\text { 1. By 2017, clear new designations have been } \\
\text { established and formalised for Araoua and Tleta- } \\
\text { Rissana based on their status as essential areas } \\
\text { for Great Bustard survival in Morocco. }\end{array}$ & $\begin{array}{l}\text { By } 2017 \text {, new legal site designations in place } \\
\text { with clearly demarcated site boundaries and } \\
\text { conditions of use }\end{array}$ & - Government documents of formal designations \\
\hline $\begin{array}{l}\text { 2. By } 2018, \text { mechanisms and incentives are } \\
\text { in place to promote the 'Plan Maroc Vert' in all } \\
\text { current and former Great Bustard lek areas. }\end{array}$ & $\begin{array}{l}\text { By 2017, mechanisms in place under the 'Plan } \\
\text { Maroc Vert' to promote traditional agriculture in } \\
\text { northwest Morocco }\end{array}$ & - 'Plan Maroc Vert' documents ans plans \\
\hline $\begin{array}{l}\text { 3. By } 2018 \text {, agreements are being implemented } \\
\text { to secure a mosaic of habitats that benefit Great } \\
\text { Bustards in Araoua and Tleta-Rissana. }\end{array}$ & $\begin{array}{l}\text { By 2018, adoption of bustard-friendly farming } \\
\text { methods in Araoua and Tleta-Rissana linked to } \\
\text { the Plan Maroc Vert and additional agreements }\end{array}$ & $\begin{array}{l}\text { - Site visits to traditional farms } \\
\text { - Project and local meeting reports } \\
\text { - Bustard monitoring reports (especially from } \\
\text { breeding season) }\end{array}$ \\
\hline $\begin{array}{l}\text { 4. By } 2020 \text {, agreements have been reached to } \\
\text { reinstate Tendafel, Kanouat and Chekbouchan } \\
\text { as potential lek areas with appropriate } \\
\text { undisturbed habitat available. }\end{array}$ & $\begin{array}{l}\text { By } 2020 \text {, agreements in place for adopting } \\
\text { bustard-friendly farming in Tendafel, Kanouat } \\
\text { and Chekbouchan }\end{array}$ & $\begin{array}{l}\text { - Written local agreements } \\
\text { - Meeting reports }\end{array}$ \\
\hline
\end{tabular}

\section{S4 - Strengthen awareness and valuation}

LTO By 2025, rural communities in northwest Morocco are benefiting from an increasing population of Great Bustards through sustainable economic enterprises.

1. By 2017, inhabitants in Araoua and TletaRissana are aware about the vital role of their land to save the Great Bustard in Morocco, about new conservation measures underway and the need to minimise disturbance.

\section{By 2019, awareness of Great Bustard} conservation measures is entrenched within public institutions, especially schools.

\section{By 2020 , a community-based economic} incentives programme is underway, likely to include branding of 'Great Bustard' products.

4. By 2020, low-level ecotourism initiatives are under operation that feature Great Bustards in their itinerary.

\begin{abstract}
At least $75 \%$ of the population in Araoua and Tleta-Rissana are aware about the Great Bustard and measures to protect it by 2017
\end{abstract}

All school pupils in project area are aware about Great Bustard conservation by 2018

High level of awareness about Great Bustards in government institutions and centres of learning

By 2020, economic incentives / branding initiatives are underway, bringing 'bustard benefits' to local communities

By 2020, low-level ecotourism initiatives in Araoua and Tleta-Rissana in particular are operating, bringing benefit to local communities

\section{- Interviews}

- Meeting / campaign reports

- Awareness materials

\section{- School visits}

- Meetings with government agencies / colleges

- Curricula, with Great Bustard featured

- Interest in / adoption of Great Bustard / agricultural research

- Economic incentive agreements

- Great Bustard branded products

- Project reports and minutes of local meetings

- Ecotourism schedules and tour reports

- Advertised tour itineraries

- Project reports, detailing ecotourism data and incomes

\section{S5 - Research and monitoring}

LTO By 2025, effective research and monitoring of population trends, behaviour, movements, habitat requirements and other parameters have yielded conservation solutions, enabling the Great Bustard population to increase.

1. 2016-2025: Censuses of Great Bustards (and sex ratios) in Araoua and Tleta-Rissana are conducted annually during early spring, and every three years across all leks to determine population trends.

\section{2016-2025: A casualty transect monitoring} programme is established and implemented, to monitor bird casualties caused by power lines in all lek areas.

3. By 2017 , a programme of integrated research is established to investigate the conservation status of Great Bustards throughout the year, including behaviour, movements and habitat requirements.

4. By 2018 , all identified actual and potential threats are being monitored.

5. By 2018 , there is good local capacity to conduct censuses and research.
Spring census data and population trend analyses available annually for contribution to management decisions

Casualty transect monitoring programme underway, with results informing management and policy

By 2017/18, integrated research is underway and contributing data for management decisions

Great Bustard threats well known and documented through annual monitoring activities

By 2018, there is strong national and local expertise for Great Bustard research and monitoring; écogardes and other trainees have capacity to conduct censuses and research.

- Census reports

- Écogardes trained in casualty transect monitoring

- Transect monitoring field notes and results

- Integrated research programme published

- Individual research projects

- Annually, research project results and papers

- Monitoring reports and analyses

- Training programmes, reports and course evaluations

- Trainee certificates

- Écogarde annual work evaluations 
Strategic Objective

S6 - Sustainable funding

LTO: By 2025, Great Bustard conservation in Morocco is assured through secured sustainable financing mechanisms.

\begin{tabular}{|l|l|l|}
\hline $\begin{array}{l}\text { 1. In 2016, the agreement between HCEFLCD } \\
\text { and the LGV is functional and funds are available } \\
\text { for immediate mitigating actions. }\end{array}$ & $\begin{array}{l}\text { Between 2016 and 2018, the LGV (ONCF) } \\
\text { directly finances urgent Great Bustard } \\
\text { conservation activities through a signed } \\
\text { agreement between HCEFLCD and the LGV }\end{array}$ & $\begin{array}{l}\text { - Signed convention / agreement with plans for } \\
\text { mitigating measures } \\
\text { - Annual project reports and finance reports }\end{array}$ \\
\hline $\begin{array}{l}\text { 2. By 2017, additional external funds and } \\
\text { partnerships are in place, especially to address } \\
\text { priority issues of poaching and collisions. }\end{array}$ & $\begin{array}{l}\text { By 2017, additional partnerships are forged } \\
\text { and resources secured for Great Bustard } \\
\text { conservation, which continue into the future }\end{array}$ & $\begin{array}{l}\text { - Partnership agreements and new project } \\
\text { documents } \\
\text { - Agreed financing of components of the action } \\
\text { plan } \\
\text { - A potential twinning mechanism underway, } \\
\text { with documentation and web presence }\end{array}$ \\
\hline $\begin{array}{l}\text { 3. By 2018, government commitments are } \\
\text { secured for long-term financing of local } \\
\text { surveillance. }\end{array}$ & $\begin{array}{l}\text { By 2018, the Moroccan government has } \\
\text { committed to long-term financing of surveillance } \\
\text { operations }\end{array}$ & $\begin{array}{l}\text { - Government plans and protocols; local } \\
\text { arrangements in place }\end{array}$ \\
\hline $\begin{array}{l}\text { 4. By 2020, Great Bustard conservation is fully } \\
\text { integrated into annual government budgets. }\end{array}$ & $\begin{array}{l}\text { By 2020, the Moroccan government has fully } \\
\text { integrated Great Bustard conservation into its } \\
\text { annual budget and plans }\end{array}$ & $\begin{array}{l}\text { - Government plans and protocols; local } \\
\text { implementation arrangements in place }\end{array}$ \\
\hline
\end{tabular}




\section{Implementation of the Conservation Action Plan}

\subsection{Considerations for implementation and need for review}

This action plan presents a range of actions for implementation within the first two to three years of the 'project' to save the Great Bustard in Morocco. This is essential because no provisions are currently in place to safeguard this population, which has been identified by Morocco as a priority species for conservation. Although the Great Bustard itself is a protected species in the country, its only remaining sites do not benefit from any specific bustard conservation or management measures on the ground, and the limited existing site designations as SIBEs and partial inclusion within a Ramsar Site are not strong enough. The population is in decline and has reached a stage where urgent action is required if the species is to have any chance of escaping extinction as a breeding population.

Stakeholders at the Great Bustard workshop in September 2014 stipulated that no measures should be taken to either to introduce birds from another country (e.g. Spain) to Morocco or to rear bustards in captivity, unless the situation was critical. The situation has probably not reached that critical point yet (J.C. Alonso, in litt. 2015), as populations elsewhere have recovered from similar numbers as a direct result of intensive conservation measures. Thus, the action plan does not describe any actions related to ex-situ conservation measures. However, the situation is close to critical, and if censuses in the next few years indicate that the population continues to decline or that breeding males reach only about five birds, then the stakeholders may wish to review their earlier decision. In such a case, captive breeding of Moroccan birds would seem to be a non-viable option, due to the extremely low stock remaining and the proven difficulty of captive breeding. Thus, introduction of bustards from Spain (the closest birds genetically to Great Bustards in Morocco, and the largest stock of wild bustards worldwide) in some form or other may need to be considered.

Alonso et al. (2015) considered that, although measures reinforcing productivity are desirable, adult mortality represents currently the main threat in Morocco, and thus any human-induced adult mortality cause should be eliminated through an intensive and permanent surveillance of all existing breeding areas by full-time, specialized guards, together with agrienvironmental measures directed to improve habitat quality and enable a successful breeding. Minimisation of power line collision mortality requires urgent attention, backed up by monitoring through collision transects. These considerations are matched well by the threat ranking and prioritisation of actions given in this plan. However, things can change, and given that the bustards are mainly limited to two breeding areas, the threat of agricultural intensification in these areas may become a higher priority.

For these and other reasons, it is advised to review the action plan every three years in light of results from population and project monitoring.

\subsection{Practicalities}

Implementation of this action plan requires a presence of conservation personnel within the main bustard strongholds. As the main areas are rather remote, it would make sense to establish a small project base within Araoua, for example at the village of Had Gharbia. Although Asilah is not too far away, it is not a practical project centre for écogardes or for most proposed activities. This may require purchase or rent of a suitable building in Araoua. Such a building could also serve (if appropriate) as an awareness centre (e.g. Maison d'Environnement). It would be desirable to also have a small project base in Tleta-Rissana, which could perhaps be negotiated on a local level and mainly serve as a meeting point for écogardes and project coordination staff.

The project also requires a full-time coordinator, ideally supported by an assistant. The ideal scenario would be a Project Coordinator tasked with managing the project and network of écogardes, and a research assistant, tasked with planning the censuses and other research activities. It may be necessary to source / provide accommodation for these staff, as it is unlikely they would be already resident in the area.

Implementation requires a network of people charged with surveillance responsibilities, here termed écogardes. The number of écogardes hired will depend to a certain extent on resources, but a minimum would be two in the Araoua area and two in Tleta-Rissana. The project team will also require equipment and the means to carry out their work, notably transport, research equipment, mobile phones and uniforms. Such equipment is standard in Moroccan protected areas.

A steering group or coordination committee is essential from year 1 to guide the implementation and take decisions. 


\section{Acknowledgements}

This action plan has involved a number of people and organisations who have given time and resources towards ensuring its inception, development and publication. The IUCN Centre for Mediterranean Cooperation has coordinated the process, led by Violeta Barrios, with support of Catherine Numa, Sonsoles San Román and Antonio Troya. A key event was the stakeholder workshop held in Asilah in September 2014, which was facilitated by Chris Magin. All participants, including international experts and members of Moroccan agencies (listed in Appendix I) are sincerely thanked for their active input and constructive contributions. Nigel Collar (Chair of the Bustard SG), Juan Carlos Alonso and Carlos Palacín all provided critical advice and support during the development of this plan.

Tim Dodman (compiler) undertook a fact-finding mission in Morocco in March 2015, which complemented the workshop. He received excellent support in planning and executing the mission from Rachid El Khamlichi and Imad Cherkaoui (GREPOM). He also warmly thanks everyone he met and interviewed during the mission (listed in Appendix II). Imad Cherkaoui also supported the whole project along with others in the GREPOM network, notably Abdeljebbar Qninba, who was lead author of the document "La grande outarde (Otis tarda) au Maroc : État des connaissances sur l'espèce", an excellent precursor to this action plan.

Another notable event in March 2015 was the Great Bustard census led by Juan Carlos Alonso and Carlos Palacín, of the Consejo Superior de Investigaciones Científicas, Madrid, Spain, who have played a leading role in Great Bustard research in Morocco. They and all census participants are thanked for their hard field work and efficient reporting.

The development of the plan would not have been possible without the active coordination and engagement of the Haux Commissariat aux Eaux et Forêts et de la Lutte Contre la Désertification. Clearly, this commission is dedicated to ensuring the Great Bustard does not decline further in Morocco, and will no doubt play a leading role in implementation of this action plan. In particular, Rachid Aboulouafae, Zouhair Amhaouch, Abdelaziz Hajaji, Said Mekkak, Hayat Mesbah and Mohamed Noaman have all contributed significantly.

The real guardians of the Great Bustard in Morocco are the local farmers and shepherds on whose land the bustards live. Despite the declining status of the bustard, some of the local communities within the Great Bustard areas are clearly proud to share their land with bustards and keep a close eye out for anything that constitutes a threat.

Finally, the IUCN Centre for Mediterranean Cooperation sincerely thanks the MAVA Foundation for providing funding for the development of the plan.

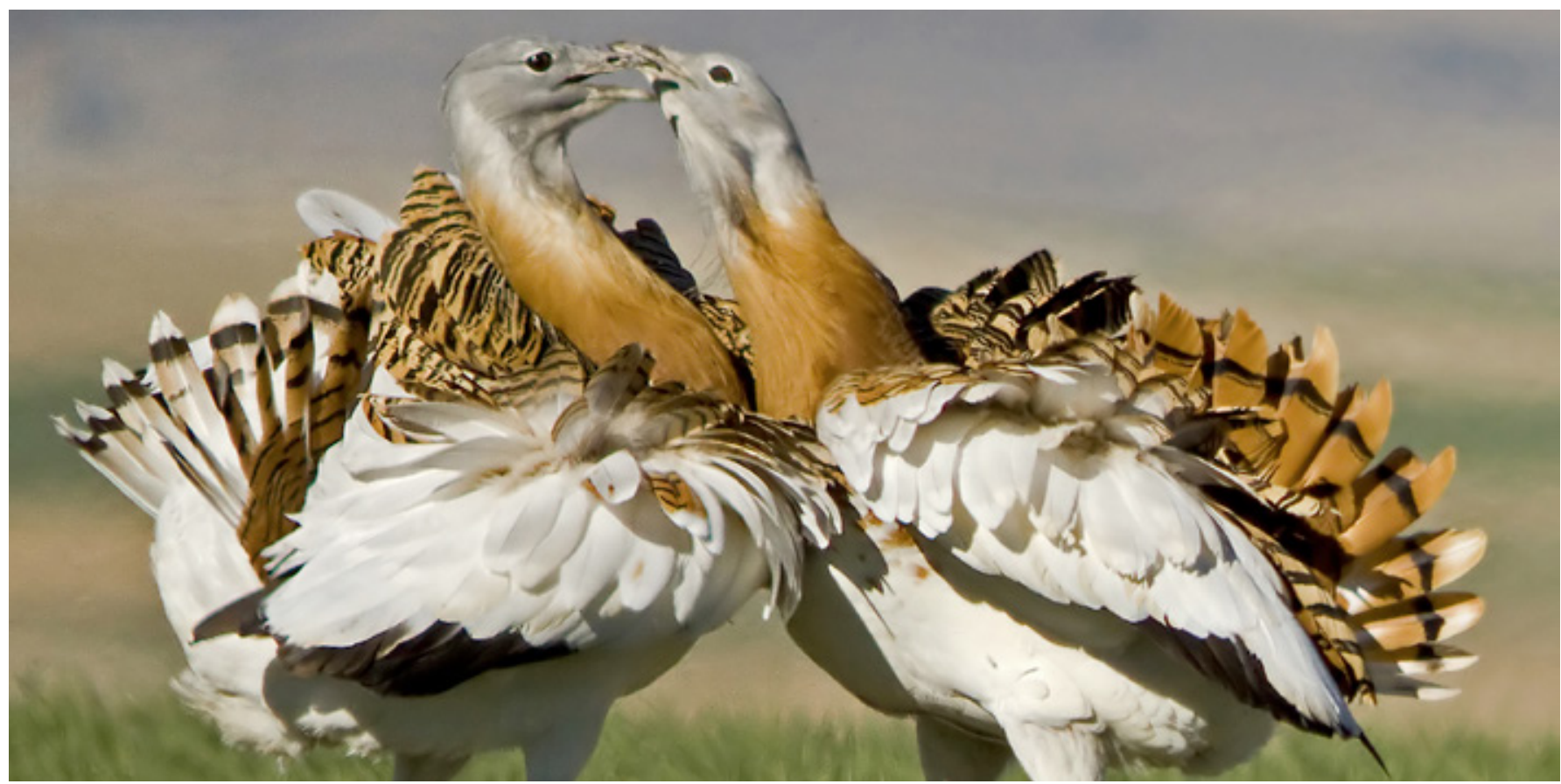

Great Bustards fighting (photo @ C Carlos Palacín) 


\section{Acronyms}

ADM Société Nationale des Autoroutes du Maroc

AESVT Association des enseignants en sciences de la vie et de la terre de Tanger

CITES Convention on International Trade in Endangered Species of Wild Fauna and Flora

CMS Convention on the Conservation of Migratory Species of Wild Animals

CSIC Consejo Superior de Investigaciones Científicas (Museo Nacional de Ciencias Naturales, Madrid)

EIA Environmental Impact Assessment

ENA École Nationale d'Agriculture de Meknès

GREPOM Groupe de Recherche pour la Protection des Oiseaux au Maroc

HCEFLCD Haux Commissariat aux Eaux et Forêts et de la Lutte Contre la Désertification

IBA Important Bird and Biodiversity Area

IUCN International Union for Conservation of Nature

LGV L Ligne de Train à Grande Vitesse (High-speed Train Line)

LTO Long-term Objective

MAPM Ministère de l'Agriculture et de la Pêche maritime

METL Ministère de l'Équipement, du Transport et de la Logistique

ONCF Office National des Chemins de Fer (National Railways Office)

ONE Office National de l'Électricité (National Electricity Office)

SEEPOM Association d'Éducation Environnementale et de Protection des Oiseaux au Maroc

SIBE Site d'Intérêt Biologique et Écologique (Site of Biological and Ecological Interest)

SG Specialist Group

SSC Species Survival Commission

TGV Train à Grande Vitesse (High-speed Train) 


\section{Bibliography}

Alonso, J.C. (coord.). 2004. Viabilidad de la población de Avutardas de Marruecos. Bases científicas para su conservación. Unpublished report. AECl-CSIC, Madrid.

Alonso, J.C., Palacín, C. and Onrubia, A. 2015. Status of the Great Bustard (Otis tarda) in Morocco: update 2015. Museo Nacional de Ciencias Naturales, Consejo Superior de Investigaciones Científicas (CSIC), España / Haut Commissariat aux Eaux et Forêts et à la Lutte Contre la Désertification, Royaume du Maroc.

Alonso, J.C. et Palacín, C. 2010. The world status and population trends of the Great Bustard (Otis tarda): 2010 update. Chinese Birds 1: 141-147.

Alonso, J.C., Martín, C.A., Alonso, J.A., Palacín, C., Magaña, M., Lieckfeldt, D. and Pitra, C. 2009a. Genetic diversity of the great bustard in Iberia and Morocco: risks from current population fragmentation. Conservation Genetics 10(2): 379-390.

Alonso, J.C., Palacín, C., Alonso, J.A. and Martín, C.A. 2009b. Post-breeding migration in male great bustards: low tolerance of the heaviest Palaearctic bird to summer heat. Behavioral Ecology and Sociobiology 63: 1705-1715.

Alonso, J.C., Palacín, C., Martín, C.A., Mouati, N., Arhzaf, Z.L. and Azizi, D. 2005. The Great Bustard Otis tarda in Morocco: a re-evaluation of its status based on recent survey results. Ardeola, 52(1): 79-90.

Alonso, J.C., Palacín, C. and Martín, C.A. 2003. Status and recent trends of the great bustard (Otis tarda) population in the Iberian peninsula. Biol. Conserv. 110: 185-195.

Alonso, J.A., Martín, C.A., Alonso, J.C., Morales, M.B. and Lane, S.J. 2001. Seasonal movements of male great bustards (Otis tarda) in central Spain. Journal of Field Ornithology 72: 504-508.

Alonso, J.C., Morales, M.B. and Alonso, J.A. 2000a. Partial migration, and lek and nesting area fidelity in female great bustards. The Condor 102: 127-136.

Alonso, J.C., Lane, S.J., Dawson, R. and Idaghdour, Y. 2000b. Great bustards Otis tarda in Morocco: status in spring 1999 and evidence of a decline in recent decades. Oryx 34: 141-146.

Alonso, J.C., Alonso, J.A. and Muñoz-Pulido, R. 1994. Mitigation of bird collisions with transmission lines through groundwire marking. Biological Conservation 67: 129-134.

Arhzaf, Z.L. 2010. Contribution à l'étude des causes de régression de la Grande Outarde (Otis tarda L., 1758) au Maroc. Thèse de Doctorat, Université Mohammed V-Agdal, Faculté des Science, Rabat, 125 pp.
Barrientos, R., Ponce, C., Palacín, C., Martín, C.A., Martín, B. and Alonso, J.C. 2012. Wire marking results in a small but significant reduction in avian mortality: a BACl designed study. PLOS ONE 7(3): e32569. doi:10.1371/journal.pone.0032569.

Barrientos, R., Alonso, J.C., Ponce, C. and Palacín, C. 2011. Meta-Analysis of the effectiveness of marked wire in reducing avian collisions with power lines. Conservation Biology 25: 893-903.

BirdLife International 2013. Otis tarda. The IUCN Red List of Threatened Species. Version 2015.2.

www.iucnredlist.org. Downloaded on 17 August 2015.

Dakki, M., El Agbani, M.A. and Qninba, A. (Eds). 2011. Zones humides du Maroc inscrites jusqu'en 2005 sur la Liste de la Convention de Ramsar. Trav. Inst. Sci., Rabat, Sér. Générale, 7.

Faragó, S. 1986. Suggestion for keeping register booklike records of European Great Bustard (Otis tarda tarda, Linne 1758) populations. 5th ICBP Bustard Symposium. Szarvas, Hungary.

Hellmich, J. and Idaghdour, Y. 2002. The great bustard Otis tarda population in Morocco in 1998-2001. Bird Conservation International, 12, 19-33.

Horreo, J.L., Alonso, J.C., Palacín, C. and Milá, B. 2014. Genetic structure in Iberian and Moroccan populations of the globally threatened great bustard (Otis tarda): a microsatellite perspective. Journal of Avian Biology 45: 507-513.

Kessler, A.E., Batbayar, N., Natsagdorj, T., Batsuur, D., and Smith, A.T. 2013. Satellite telemetry reveals longdistance migration in the Asian great bustard Otis tarda dybowskii. Journal of Avian Biology, 44: 001010.

Lane, S.J., Alonso, J.C. and Martín, C.A. 2001. Habitat preferences of great bustard Otis tarda flocks in the arable steppes of central Spain: are potentially suitable areas unoccupied? Journal of Applied Ecology 38: 193-203.

LIFE Impacto Cero. 2014. Development and demonstration of an anti bird-strike tubular screen for High Speed Rail lines. LIFE+ 2012 Biodiversity project BIO/ES/000660. 2013-17.

Martín, B., Martín, C.A., Palacín, C., Magaña, M., Alonso, J.A., and Alonso, J.C. 2004. Effect of collision with power lines on the viability of the Great Bustard metapopulation in Madrid province. Poster, International Symposium on Ecology and Conservation of Steppe-land Birds, Lleida. 
Morales, M.B., Alonso, J.C., Alonso, J.A. and Martin, E. 2000. Migration patterns in male great bustards. The Auk 117: 493-498.

Nagy, S. 2009. International single species action plan for the Western Palearctic population of Great Bustard, Otis tarda tarda. BirdLife International, Cambridge.

Palacín, C., Martín, B., Onrubia, A. and Alonso, J.C. 2016. Assessing the extinction risk of the great bustard Otis tarda in Africa. Endang. Species Res. 30: 73-82.

Palacín, C., Alonso, J.C., Martín, C.A. and Alonso, J.A. 2012. The importance of traditional farmland areas for steppe birds: a case study with migrant Great Bustard Otis tarda females. Ibis 154: 85-95.

Palacín, C., Alonso, J.C., Alonso, J.A., Martín, C.A. and Magaña, M. 2011. Cultural transmission and flexibility of partial migration patterns in a long-lived bird. Journal of Avian Biology, 42, 301-308.

Palacín, C., Alonso, J.C., Alonso, J.A., Martín, C.A., Magaña, M. and Martín, B. 2009. Differential migration by sex in the great bustard. Possible consequences of an extreme sexual size dimorphism. Ethology, 115, 617-626.

Palacín, C. and Alonso, J.C. 2008. An updated estimate of the world status and population trends of the Great Bustard Otis tarda. Ardeola 55: 13-25.

Qninba, A. 2016. La grande outarde (Otis tarda) au Maroc : État des connaissances sur l'espèce. Report for IUCN Centre for Mediterranean Cooperation.

Raab, R., Schütz, C., Spakovszky, P., Eike, J. and Schulze, C.H. 2012. Underground cabling and marking of power lines: conservation measures rapidly reduced mortality of West-Pannonian Great Bustards Otis tarda. Bird Conservation International, 22, 299306.

Streich, W.J., Litzbarski, H., Ludwig, B. and Ludwig, S. 2006. What triggers facultative winter migration of Great Bustard (Otis tarda) in Central Europe? Eur. J. Wildlife Res., Vol. 52(1): 48-53.

Thévenot, M., Vernon, R. and Bergier, P. 2003. The Birds of Morocco. British Ornithologists' Union, Checklist series no. 20, Tring, UK. 594 pp.

Torres, A., Palacín, C., Seoane, J. and Alonso, J. C. 2011. Assessing the effects of a highway on a threatened species using Before-During-After and Before-DuringAfter-Control-Impact designs. Biological Conservation, 144, 2223-2232.

Watzke, H. 2007. Results from satellite telemetry of Great Bustards in the Saratov region of Russia. Bustard Studies 6: 83-98. 


\title{
Appendix I: Overview of Stakeholder Workshop
}

\author{
Workshop Summary
}

The Strategy for the conservation of the Great Bustard Otis tarda (Vulnerable) in Morocco Stakeholder Strategy Development Workshop was held from 17-19 September 2014 in Asilah, Morocco. The workshop comprised presentations, working groups and a field visit. There were 27 participants: 20 from Morocco, 2 Great Bustard experts from Spain and 1 from Austria, 3 IUCN-Mediterranean office staff members, and the facilitator. The workshop aimed to develop a Vision, Goal, Objectives and Actions to form the core of a Species Action Plan or Strategy to conserve the Great Bustard population in Morocco.

Due to time constraints it was not possible to develop detailed actions during the workshop. Participants agreed however that ex-situ captive breeding using Moroccan birds or eggs as a source population should not be considered as an action. They also agreed that reinforcement of the population with birds from other countries should only be contemplated as a last resort if in-situ efforts failed to stabilise the population decline.

The workshop was organised by the IUCN Centre for Mediterranean Cooperation and the Haut Commissariat aux Eaux et Forêts et de la Lutte Contre la Désertification (HCEFLCD), with support from the Groupe de Recherche pour la Protection des Oiseaux au Maroc (GREPOM) and with financial support from the MAVA Foundation.

\section{Workshop Participants}

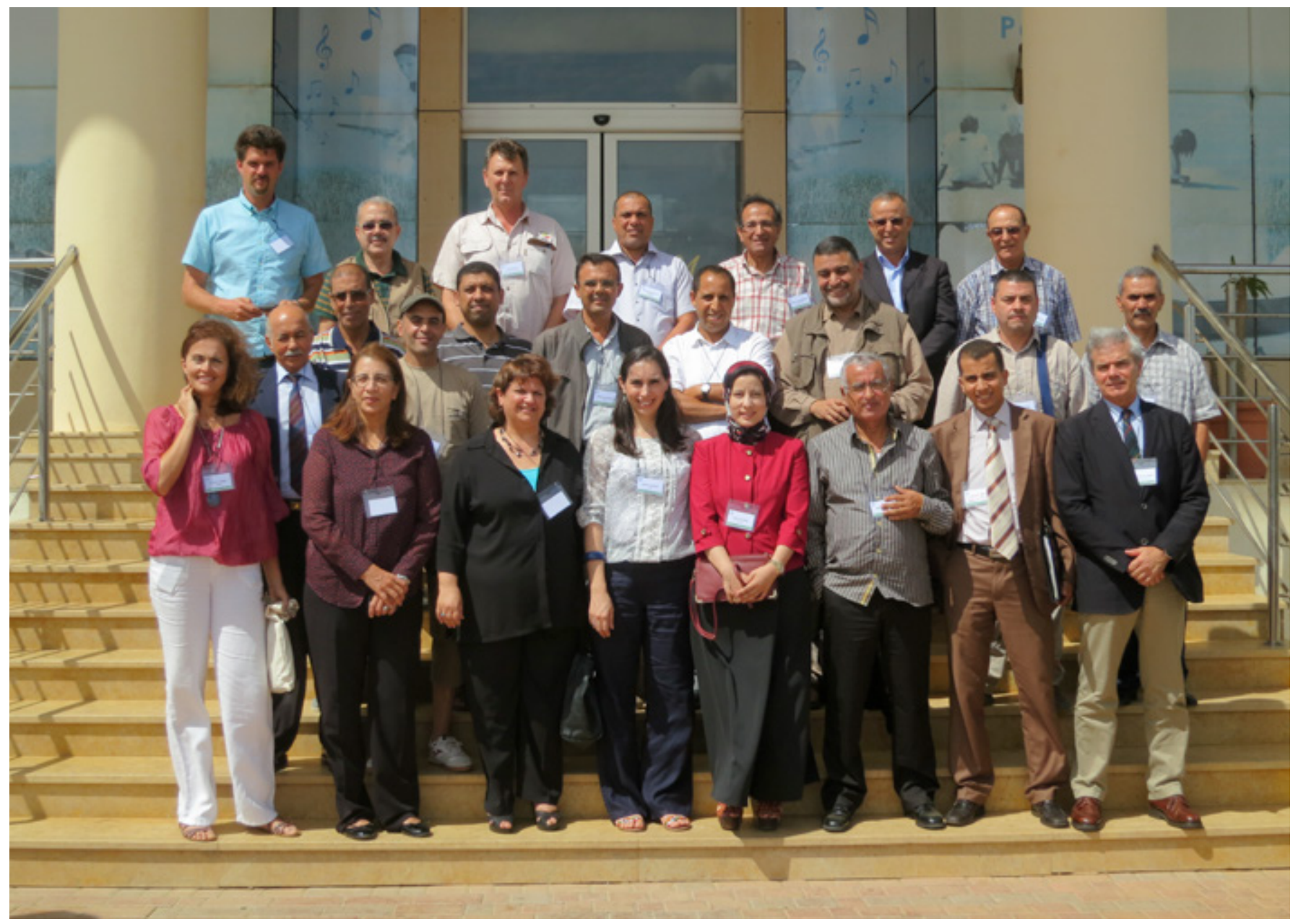

Workshop participants on the steps of the Hotel Asilah Marina Golf, Asilah, Morocco (Photo @ IUCN-Med) 


\begin{tabular}{|c|c|}
\hline Name & Institution \\
\hline ABOULOUAFAE Rachid & $\begin{array}{l}\text { Direction Régionale HCEFLCD du Rif - Tétouan ; Service du Partenariat pour la } \\
\text { Conservation et le Développement des Ressources Naturelles }\end{array}$ \\
\hline ALONSO Juan Carlos & $\begin{array}{l}\text { Museo Nacional de Ciencias Naturales, Madrid - Consejo Superior de } \\
\text { Investigaciones Científicas (CSIC) }\end{array}$ \\
\hline AZIZI Driss & $\begin{array}{l}\text { Association d'Éducation Environnementale et de Protection des Oiseaux au } \\
\text { Maroc (SEEPOM) }\end{array}$ \\
\hline BARRIOS Violeta & Centre de Coopération pour la Méditerranée de l'UICN \\
\hline BOUABBAD Abdelaziz & $\begin{array}{l}\text { Direction Régionale du HCEFLCD du Rif - Tétouan } \\
\text { Centre de la Conservation et du Développement des Ressources Forestières } \\
\text { d'Assilah }\end{array}$ \\
\hline BOUSFIZZA Med & GREPOM \\
\hline BRITEL Abderraouf & Directeur Provincial - Tanger, HCEFLCD \\
\hline CHAKER Younis & $\begin{array}{l}\text { Direction Régionale du HCEFLCD du Rif - Tétouan } \\
\text { Service de la Programmation, de la Valorisation et de l'Évaluation }\end{array}$ \\
\hline CHAKRI Said & $\begin{array}{l}\text { Association des Enseignants des Sciences de la Vie et de la Terre de Tanger } \\
\text { (AESVT) }\end{array}$ \\
\hline CHERKAOUI Imad & Directeur exécutif, GREPOM \\
\hline EL AGBANI Mohammed Aziz & Institut Scientifique de Rabat/Vice-Président du GREPOM \\
\hline EL IDRISSI ESSOUGRATI Abdelaziz & GREPOM \\
\hline EL KHAMLICHI Rachid & GREPOM Tétouan \\
\hline HADDANE Brahim & UICN, Conseiller pour Afrique \\
\hline HIMMI Oumnia & Institut Scientifique de Rabat/Membre du GREPOM \\
\hline MAGIN Chris & Royal Society for the Protection of Birds (RSPB) \\
\hline MESBAH Hayat & $\begin{array}{l}\text { Chef de Service de la Conservation de la Flore et de la Faune sauvage, } \\
\text { HCEFLCD }\end{array}$ \\
\hline NOAMAN Mohamed & Service de la Conservation de la Flore et de la Faune sauvage, HCEFLCD \\
\hline NUMA Catherine & Centre de Coopération pour la Méditerranée de l'UICN \\
\hline OUAFAE Azzat & $\begin{array}{l}\text { Direction Régionale du HCEFLCD de Fès-Boulemane - Fès ; Centre Technique } \\
\text { pour le Développement des Ressources Cynégétiques }\end{array}$ \\
\hline PALACÍN Carlos & $\begin{array}{l}\text { Museo Nacional de Ciencias Naturales, Madrid - Consejo Superior de } \\
\text { Investigaciones Científicas (CSIC) }\end{array}$ \\
\hline QNINBA Abdeljebbar & Institut Scientifique de Rabat/Membre du GREPOM \\
\hline RAAB Rainer & Great Bustard Conservation Team/coordinateur pour l'Europe centrale \\
\hline RADI Mohamed & École Normale Supérieure de Marrakech/Membre du GREPOM \\
\hline SALMI MRABET Ahmed & Directeur du Groupe scolaire de Hjar N'hal \\
\hline SIDI BEN SALAH Mustapha & $\begin{array}{l}\text { Association des Enseignants des Sciences de la Vie et de la Terre de Tanger } \\
\text { (AESVT) }\end{array}$ \\
\hline
\end{tabular}




\section{Appendix II: Action Plan Development Mission, March 2015}

\section{Mission Overview}

A mission was undertaken by Tim Dodman, compiler of the action plan, from 12-19 March 2015 in order to gauge a deeper understanding of the issues relevant for Great Bustard conservation, through site visits and interviews. Imad Cherkaoui (GREPOM) aided in organising the mission, which was undertaken mostly with Rachid El Khamlichi (GREPOM - Tétouan). The mission followed on from the 2015 Great Bustard census (Alonso et al. 2015).

Great Bustards were seen on three occasions - a flock of 11 birds in Araoua on $15^{\text {th }}$ March, 5 parading males and 2 females at a lek in Araoua on $16^{\text {th }}$ March and one female in an agricultural field in Tleta Rissana, also on $16^{\text {th }}$ March.

Discussions and interviews yielded significant information about Great Bustard threats and conservation issues, with many useful ideas and considerations.

The Great Bustards in Morocco inhabit a very special ecosystem, albeit modified by man, where still some traditional agricultural and pastoral practices are followed. However, it was clear that the pressures they face are very real, and it may be hard to prevent the future agricultural development of the remaining areas where bustards survive.

\section{Mission Itinerary}

The mission lasted approximately one week, and the itinerary is summarised below.

\begin{tabular}{|c|c|c|}
\hline Date & Itinerary & Activities \\
\hline Thursday $12^{\text {th }}$ March & $\begin{array}{l}\text { Arrive Rabat-Salé Airport } \\
\text { Meetings in Salé and Rabat }\end{array}$ & $\begin{array}{l}\text { Discussions at GREPOM office (Imad and } \\
\text { Adel) } \\
\text { Discussion at HCEFLCD office (Zouhair) }\end{array}$ \\
\hline Friday $13^{\text {th }}$ March & $\begin{array}{l}\text { Visit Sidi Bou Ghaba } \\
\text { Meeting Rabat }\end{array}$ & $\begin{array}{l}\text { Visit the Sidi Bou Ghaba Reserve } \\
\text { Discussion with Arhzaf (SEEPOM) }\end{array}$ \\
\hline Saturday $14^{\text {th }}$ March & \begin{tabular}{|l} 
Meeting, Rabat \\
Travel Rabat to Asilah (car) \\
Visit Tahaddart / Araoua
\end{tabular} & $\begin{array}{l}\text { Discussion with Qninba (Institute Scientifique } \\
\text { de Rabat) } \\
\text { Meet Rachid El Khamlichi (GREPOM) } \\
\text { Visit Great Bustard areas northeast of Asilah }\end{array}$ \\
\hline Sunday $15^{\text {th }}$ March & $\begin{array}{l}\text { Visit Great Bustard areas around Araoua and } \\
\text { Had Gharbia village } \\
\text { Pass through Kanouat } \\
\text { Discussion south of Tangier }\end{array}$ & $\begin{array}{l}\text { Visit bustard areas; look for bustards } \\
\text { Brief discussions with local people } \\
\text { See Kanouat area and LGV route } \\
\text { Discussion with Abdelaziz (HCEFLCD-Asilah) }\end{array}$ \\
\hline Monday $16^{\text {th }}$ March & $\begin{array}{l}\text { Visit Great Bustard areas around Araoua and } \\
\text { Tleta Rissana }\end{array}$ & Visit bustard areas; local discussions \\
\hline Tuesday $17^{\text {th }}$ March & $\begin{array}{l}\text { Visit Tendafel } \\
\text { Go to Rissana / Sidi el Yamani junction } \\
\text { Drive to Tétouan } \\
\text { Go to Tangier }\end{array}$ & $\begin{array}{l}\text { Visit Tendafel, south of Asilah } \\
\text { Discussion with Kébir } \\
\text { Discussion at HCEFLCD Tétouan office } \\
\text { (Rachid) } \\
\text { Discussion with Aziz (GREPOM) }\end{array}$ \\
\hline Wednesday $18^{\text {th }}$ March & $\begin{array}{l}\text { Travel to Rabat via Loukkos Marshes and } \\
\text { Merja Zerga }\end{array}$ & $\begin{array}{l}\text { Discussion with Abdelilah Maknass; gain } \\
\text { insight into ecotourism operations at Merja } \\
\text { Zerga }\end{array}$ \\
\hline Thursday $19^{\text {th }}$ March & Leave Rabat-Salé airport & \\
\hline
\end{tabular}


Persons Interviewed during the Mission

Interviews / discussions were held with about 15 people during the mission, including the 11 below who are involved in nature conservation, research and/or management. In addition, discussions were held with a few villagers, farmers and shepherds within the Great Bustard's range.

\begin{tabular}{|l|l|}
\hline Name & Institution \\
\hline ABDELILAH Maknass & Association Haniza Hamra pour l'écotourisme et la protection de la nature \\
\hline ABOULOUAFAE Rachid & $\begin{array}{l}\text { Direction Régionale HCEFLCD du Rif - Tétouan ; Service du Partenariat pour la } \\
\text { Conservation et le Développement des Ressources Naturelles }\end{array}$ \\
\hline AMHAOUCH Zouhair & Division des Parcs et Réserves Naturelles, HCEFLCD \\
\hline ARHZAF Zine Laabidin & Président, SEEPOM \\
\hline BOUABBAD Abdelaziz & $\begin{array}{l}\text { Direction Régionale du HCEFLCD du Rif - Tétouan } \\
\text { Centre de la Conservation et du Développement des Ressources Forestières d'Assilah }\end{array}$ \\
\hline BOUAJAJA Adel & Chargé de conservation, GREPOM \\
\hline CHERKAOUI Imad & Directeur exécutif, GREPOM \\
\hline $\begin{array}{l}\text { EL AGBANI Mohammed } \\
\text { Aziz }\end{array}$ & Institut Scientifique de Rabat/Vice-Président du GREPOM \\
\hline EL KHAMLICHI Rachid & GREPOM Tétouan \\
\hline KÉBIR Ksassoua & $\begin{array}{l}\text { Direction Régionale du HCEFLCD du Rif - Tétouan } \\
\text { Centre de la Conservation et du Développement des Ressources Forestières de Krimda }\end{array}$ \\
\hline QNINBA Abdeljebbar & Institut Scientifique de Rabat/Membre du GREPOM \\
\hline
\end{tabular}

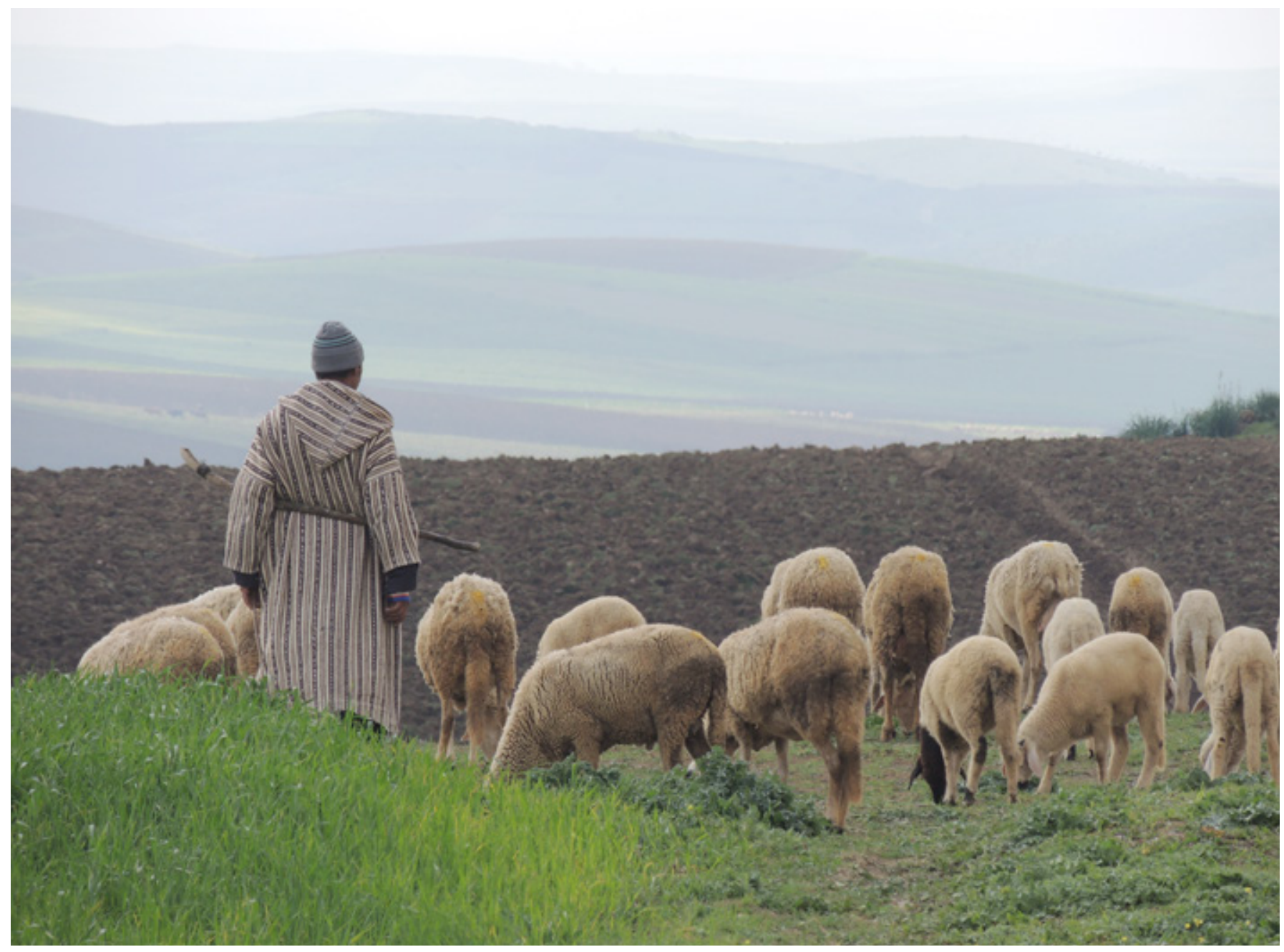

Shepherd with sheep, Tleta Rissana (photo (C) Tim Dodman) 



\section{IUCN}

INTERNATIONAL UNION

FOR CONSERVATION OF NATURE

IUCN Centre for Mediterranean Cooperation

C / Marie Curie 22

29590 Campanillas

Malaga, Spain

Tel. : +34 952028430

Fax : +34 952028145

uicnmed@iucn.org

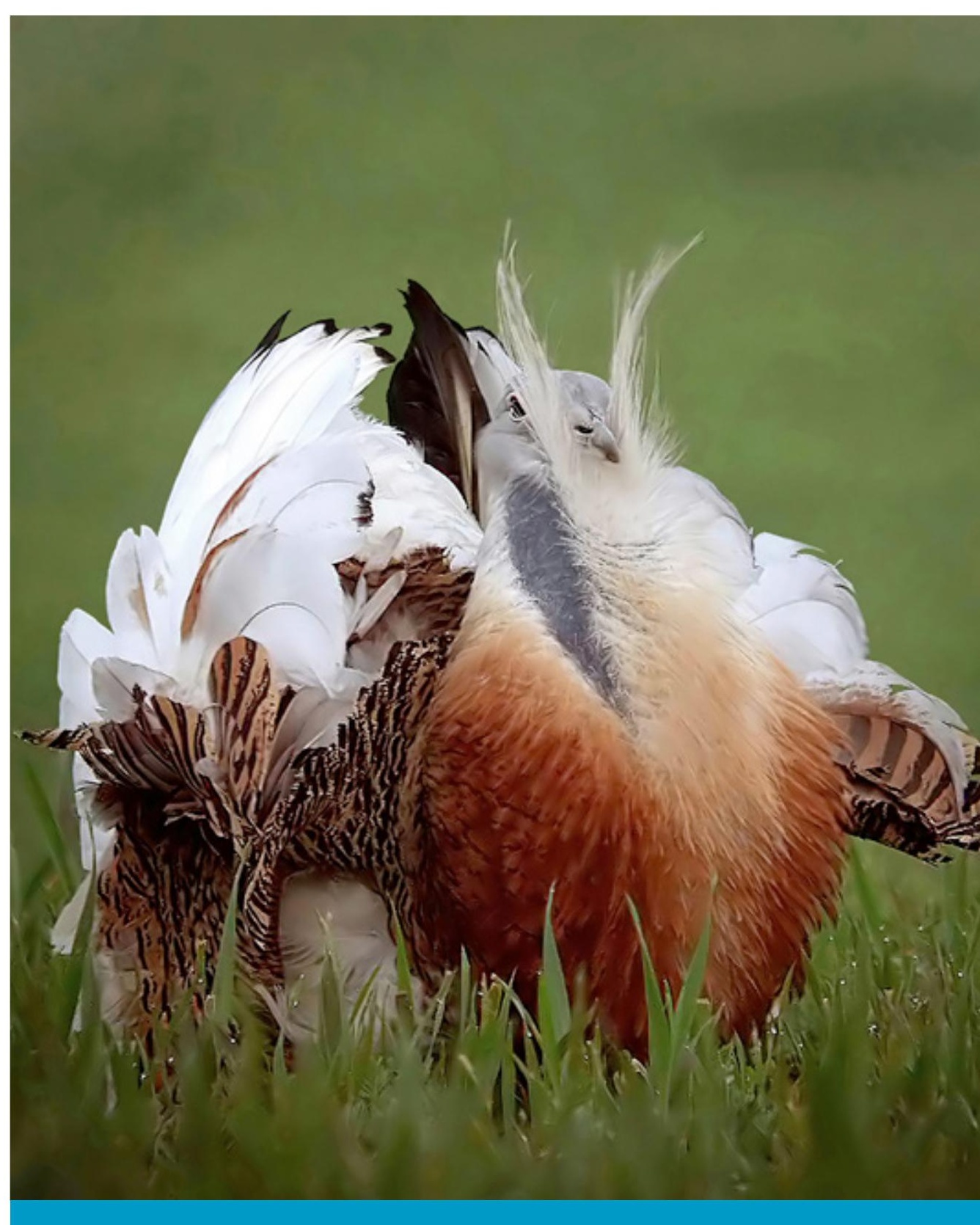

www.iucn.org/publications

www.iucn.org/mediterranean

Core support for the IUCN Centre for Mediterranean Cooperation is provided by
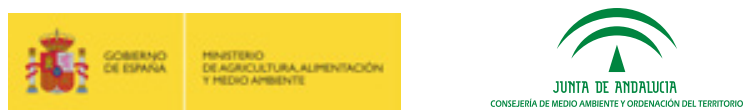